Prepared in cooperation with the Arkansas Natural Resources Commission and the Arkansas Geological Survey

\title{
Water Levels and Water Quality in the Sparta-Memphis Aquifer (Middle Claiborne Aquifer) in Arkansas, Spring- Summer 2011
}

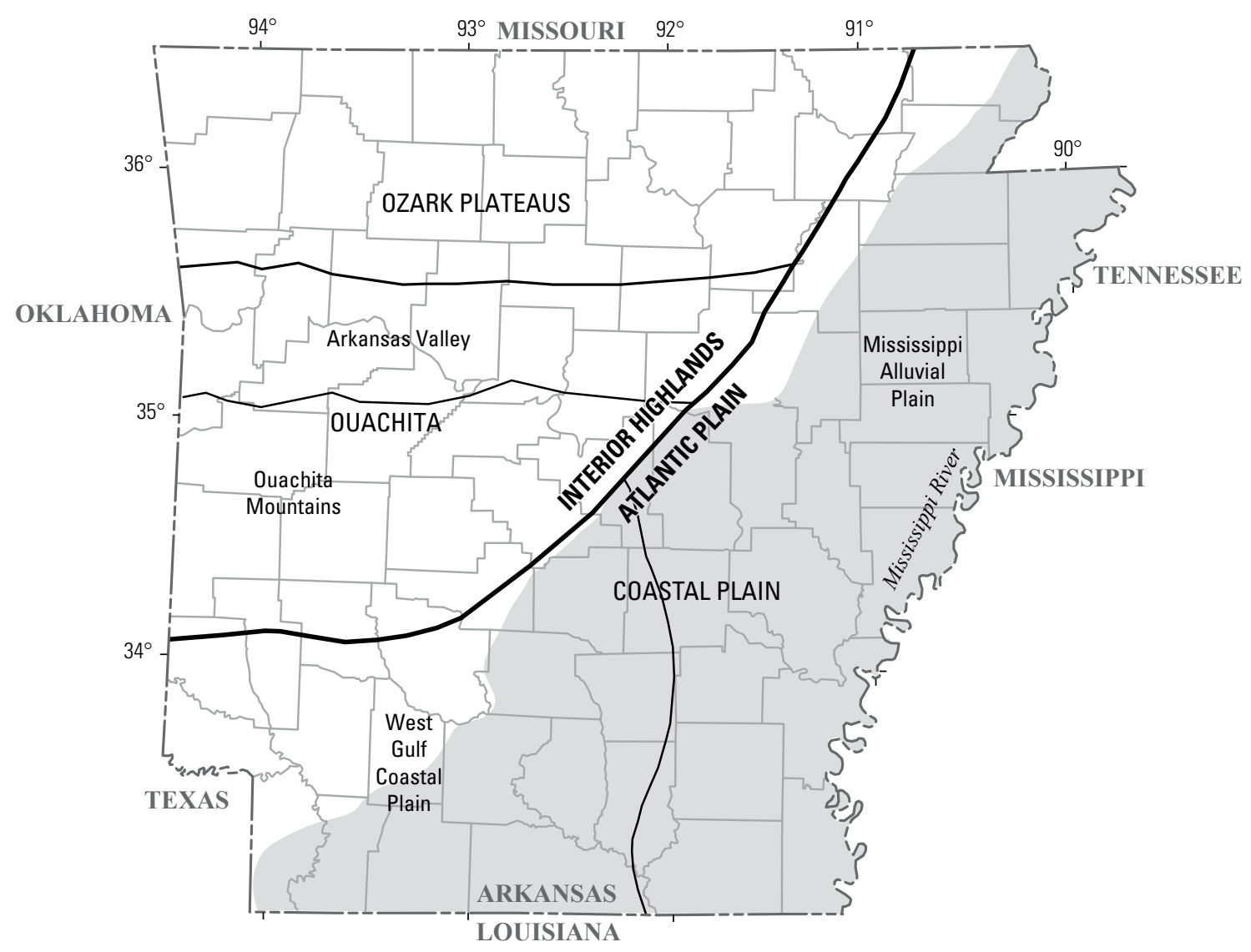

Scientific Investigations Report 2014-5044 



\section{Water Levels and Water Quality in the Sparta-Memphis Aquifer (Middle Claiborne Aquifer) in Arkansas, Spring-Summer 2011}

By T.P. Schrader

Prepared in cooperation with the Arkansas Natural Resources Commission and the Arkansas Geological Survey

Scientific Investigations Report 2014-5044 


\section{U.S. Department of the Interior \\ SALLY JEWELL, Secretary}

\section{U.S. Geological Survey \\ Suzette M. Kimball, Acting Director}

\section{U.S. Geological Survey, Reston, Virginia: 2014}

For more information on the USGS — the Federal source for science about the Earth, its natural and living resources, natural hazards, and the environment, visit http://www.usgs.gov or call 1-888-ASK-USGS.

For an overview of USGS information products, including maps, imagery, and publications, visit http://www.usgs.gov/pubprod

To order this and other USGS information products, visit http://store.usgs.gov

Any use of trade, firm, or product names is for descriptive purposes only and does not imply endorsement by the U.S. Government.

Although this information product, for the most part, is in the public domain, it also may contain copyrighted materials as noted in the text. Permission to reproduce copyrighted items must be secured from the copyright owner.

Suggested citation:

Schrader, T.P., 2014, Water levels and water quality in the Sparta-Memphis aquifer (middle Claiborne aquifer) in Arkansas, spring-summer 2011: U.S. Geological Survey Scientific Investigations Report 2014-5044, 44 p., http://dx.doi.org/10.3133/sir20145044.

ISSN 2328-031X (print)

ISSN 2328-0328 (online) 


\section{Contents}

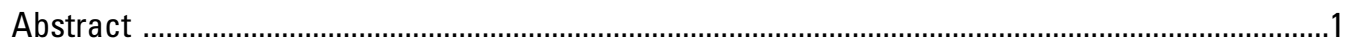

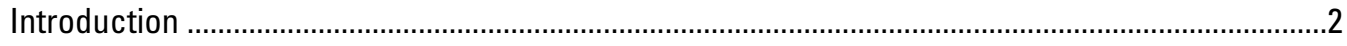

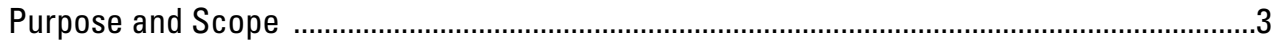

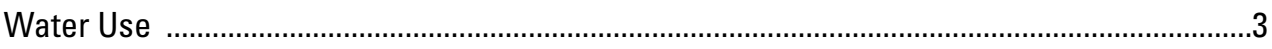

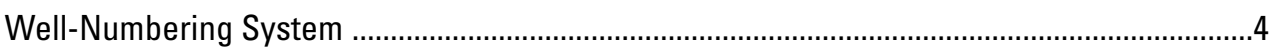

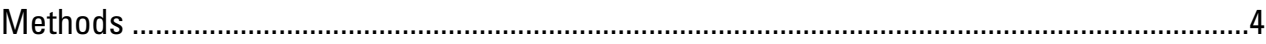

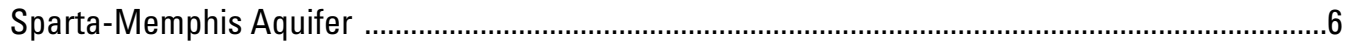

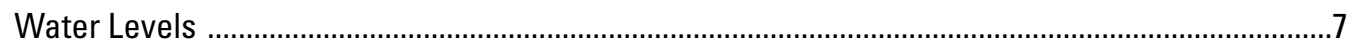

Potentiometric-Surface Map .................................................................................................

Water-Level Difference from 2007 to 2011 ...........................................................................

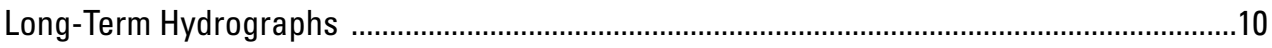

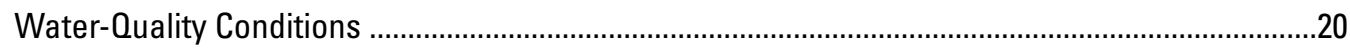

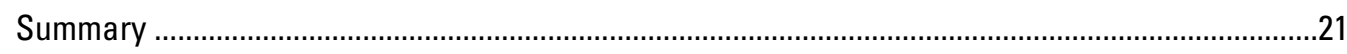

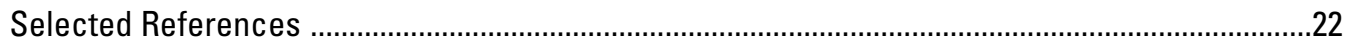

Appendixes

1. Water-level data collected during spring 2011 from wells completed in the

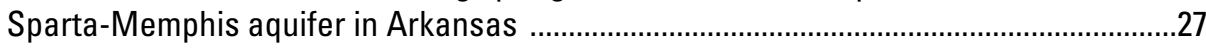

2. Difference in water level from 2007 to 2011 in the Sparta-Memphis aquifer in

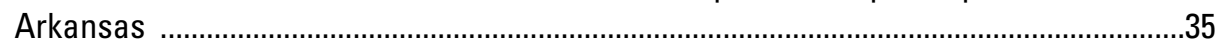

3. Specific conductance, temperature, and $\mathrm{pH}$ data from wells completed in the Sparta-Memphis aquifer in Arkansas, 2011 .....................................................................42

\section{Plates}

[In pocket]

1. Map showing potentiometric surface for the Sparta-Memphis aquifer in Arkansas, 2011

2. Map showing water-level difference for the Sparta-Memphis aquifer in Arkansas from 2007 to 2011

\section{Figures}

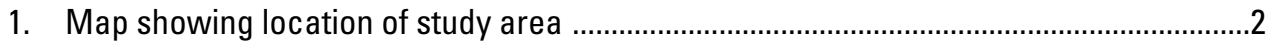

2. Graph showing water use in the Sparta-Memphis aquifer in Arkansas, 1965-2005 .......3

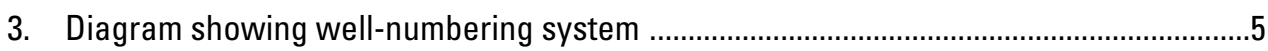

4. Map showing change in the depression in southern Arkansas, 1993-2011 ....................9

5. Hydrographs showing water levels for selected wells completed in the SpartaMemphis aquifer in Arkansas ..................................................................................12

6. Graph showing distribution of specific conductance in samples from the SpartaMemphis aquifer in 2009 and 2011 


\section{Tables}

1. Stratigraphic correlation in the northern and southern parts of Arkansas ...

2. Area within the -60-foot contour in Union County, Arkansas in 1993, 2003, 2007, and 2011

3. Number of wells, range, mean, median, and correlation coefficient $\left(R^{2}\right)$ of annual rise-decline in water level by county for wells in the Sparta-Memphis aquifer, 1987-2011

\section{Conversion Factors}

Inch/Pound to SI

\begin{tabular}{lcl}
\hline \multicolumn{1}{c}{ Multiply } & By & \multicolumn{1}{c}{ To obtain } \\
\hline foot $(\mathrm{ft})$ & Length & meter $(\mathrm{m})$ \\
mile $(\mathrm{mi})$ & 0.3048 & kilometer $(\mathrm{km})$ \\
\hline & 1.609 & \\
\hline square mile $\left(\mathrm{mi}^{2}\right)$ & Area & hectare $(\mathrm{ha})$ \\
square mile $\left(\mathrm{mi}^{2}\right)$ & 259.0 & square kilometer $\left(\mathrm{km}^{2}\right)$ \\
\hline & 2.590 & \\
\hline cubic foot $\left(\mathrm{ft}^{3}\right)$ & Volume & cubic meter $\left(\mathrm{m}^{3}\right)$ \\
\hline & 0.029329 & \\
\hline foot per year $(\mathrm{ft} / \mathrm{yr})$ & Flow rate & meter per year $(\mathrm{m} / \mathrm{yr})$ \\
gallon per minute $(\mathrm{gal} / \mathrm{min})$ & 0.3048 & liter per second $(\mathrm{L} / \mathrm{s})$ \\
million gallons per day $(\mathrm{Mgal} / \mathrm{d})$ & 0.06309 & cubic meter per second $\left(\mathrm{m}^{3} / \mathrm{s}\right)$ \\
\hline
\end{tabular}

Temperature in degrees Celsius $\left({ }^{\circ} \mathrm{C}\right)$ may be converted to degrees Fahrenheit $\left({ }^{\circ} \mathrm{F}\right)$ as follows:

${ }^{\circ} \mathrm{F}=\left(1.8 \times{ }^{\circ} \mathrm{C}\right)+32$

Temperature in degrees Fahrenheit $\left({ }^{\circ} \mathrm{F}\right)$ may be converted to degrees Celsius $\left({ }^{\circ} \mathrm{C}\right)$ as follows:

${ }^{\circ} \mathrm{C}=\left({ }^{\circ} \mathrm{F}-32\right) / 1.8$

Vertical coordinate information is referenced to the National Geodetic Vertical Datum of 1929 (NGVD 29).

Horizontal coordinate information is referenced to the North American Datum of 1983 (NAD 83).

Altitude, as used in this report, refers to distance above the vertical datum.

Specific conductance is given in microsiemens per centimeter at 25 degrees Celsius $(\mu \mathrm{S} / \mathrm{cm}$ at $\left.25^{\circ} \mathrm{C}\right)$.

Concentrations of chemical constituents in water are given either in milligrams per liter (mg/L) or micrograms per liter ( $\mu \mathrm{g} / \mathrm{L})$. 


\title{
Water Levels and Water Quality in the Sparta-Memphis Aquifer (Middle Claiborne Aquifer) in Arkansas, Spring- Summer 2011
}

\author{
By T.P. Schrader
}

\section{Abstract}

The U.S. Geological Survey, in cooperation with the Arkansas Natural Resources Commission and the Arkansas Geological Survey, has monitored water levels in the Sparta Sand of Claiborne Group and Memphis Sand of Claiborne Group (herein referred to as "the Sparta Sand" and "the Memphis Sand," respectively) since the 1920s. Groundwater withdrawals have increased while water levels have declined since monitoring was initiated. Herein, aquifers in the Sparta Sand and Memphis Sand will be referred to as "the SpartaMemphis aquifer" throughout Arkansas. During the spring of 2011, 291 water levels were measured in wells completed in the Sparta-Memphis aquifer and used to produce a regional potentiometric-surface map. During the summer of 2011, groundwater-quality samples were collected and measured from 61 wells for specific conductance, $\mathrm{pH}$, and temperature.

In the northern half of Arkansas, the regional direction of groundwater flow in the Sparta-Memphis aquifer is generally to the south-southeast and flows east and south in the southern half of Arkansas. The groundwater in the southern half of Arkansas flows away from the outcrop area except where affected by large depressions in the potentiometric surface. The highest and lowest water-level altitudes measured in the Sparta-Memphis aquifer were 326 feet above and 120 feet below National Geodetic Vertical Datum of 1929 (NGVD 29), respectively.

Five depressions are located in the following counties: Arkansas, Cleveland, Jefferson, Lincoln, and Prairie; Union; Cross, Poinsett, St. Francis, and Woodruff; Columbia; and Bradley. Two large depressions, centered in Jefferson and Union Counties, are the result of large withdrawals for industrial, irrigation, or public supply. The depression centered in Jefferson County has expanded in recent years into Arkansas and Prairie Counties as a result of large withdrawals for irrigation and public supply. The lowest water-level altitude measured in this depression is approximately 20 feet (ft) higher in 2011 than in 2009. The area enclosed within the 40 -ft contour on the 2011 potentiometric-surface map has decreased in area, shifting north in Lincoln County and west in Arkansas County when compared with the 2009 potentiometric-surface map.

The depression in Union County is roughly circular within the -60 - $\mathrm{ft}$ contour. The lowest water-level altitude measurement was $157 \mathrm{ft}$ below NGVD 29 in 2009, with a $37-\mathrm{ft}$ rise to $120 \mathrm{ft}$ below NGVD 29 in 2011. The depression in Union County has diminished and encloses a smaller area than in recent years. In 1993, the -60-ft contour enclosed 632 square miles $\left(\mathrm{mi}^{2}\right)$. In 2011, the -60 -ft contour enclosed $375 \mathrm{mi}^{2}$, a decrease of 41 percent from 1993. The lowest water-level altitude measurement during 2011 in the center of the depression in Union County represents a rise of $79 \mathrm{ft}$ since 2003. The area enclosed by the lowest altitude contour, $120 \mathrm{ft}$ below NGVD 29, on the 2011 potentiometric-surface map is less than 10 percent of the area enclosed by that same contour on the 2009 potentiometric-surface map.

A broad depression in western Poinsett and Cross Counties was first shown in the 1995 potentiometric-surface map. In 2011, the lowest water-level altitude measurement in this depression, $129 \mathrm{ft}$ above NGVD 29, is $2 \mathrm{ft}$ lower than in 2009. The 140-ft contour has extended southwest into northwestern St. Francis and east-central Woodruff Counties in 2011. In Columbia County in 2011, the area of the depression has decreased, with water levels rising about $1 \mathrm{ft}$ since 2005 in the well with the lowest water-level altitude measurement. The depression in Bradley County in 2011 has decreased in area compared to 2007.

A water-level difference map was constructed using the difference between water-level measurements made during 2007 and 2011 at 247 wells. The differences in water level between 2007 and 2011 ranged from -17.3 to $45.4 \mathrm{ft}$, with a mean of $4.1 \mathrm{ft}$. Water levels generally declined in the northern half of the study area and generally increased in the southern half of the study area. Areas with a general decline in water levels include Lonoke and western Prairie Counties; northern Arkansas County; Miller County; and Craighead, Poinsett, Cross, and Woodruff Counties. Areas with a general rise in water levels include Lafayette, Columbia, Union, Calhoun, and Bradley Counties; Grant, Jefferson, southern Arkansas, Lincoln, Drew, and Desha Counties; and Phillips County. 
Hydrographs from 183 wells with a minimum of 25 years of water-level measurements were constructed. During the period 1987-2011, county mean annual water levels generally declined. Mean annual declines were between 0.5 foot per year (ft/yr) and $0.0 \mathrm{ft} / \mathrm{yr}$ in Ashley, Chicot, Crittenden, Drew, Grant, Jefferson, Lafayette, Mississippi, Monroe, Ouachita, Phillips, Pulaski, St. Francis, and Woodruff Counties. Mean annual declines were between $1.0 \mathrm{ft} / \mathrm{yr}$ and $0.5 \mathrm{ft} / \mathrm{yr}$ in Bradley, Calhoun, Cleveland, Craighead, Cross, Desha, Lonoke, Miller, Poinsett, and Prairie Counties. Mean annual declines were between $1.5 \mathrm{ft} / \mathrm{yr}$ and $1.0 \mathrm{ft} / \mathrm{yr}$ in Arkansas, Lee, and Lincoln Counties. The county mean annual water level rose in Columbia, Dallas, and Union Counties about $0.3 \mathrm{ft} / \mathrm{yr}$, $0.1 \mathrm{ft} / \mathrm{yr}$, and $1.2 \mathrm{ft} / \mathrm{yr}$, respectively.

Water samples were collected in the summer of 2011 from 61 wells completed in the Sparta-Memphis aquifer and measured onsite for specific conductance, temperature, and $\mathrm{pH}$. Although there is a regional increase in specific conductance to the east and south, anomalous increases occur in some parts of the study area. Specific conductance ranged from 35 microsiemens per centimeter $(\mu \mathrm{S} / \mathrm{cm})$ in Ouachita County to $1,380 \mu \mathrm{S} / \mathrm{cm}$ in Monroe County. Relatively large specific conductance values (greater than $700 \mu \mathrm{S} / \mathrm{cm}$ ) occur in samples from wells in Arkansas, Ashley, Clay, Monroe, Phillips, and Union Counties.

\section{Introduction}

The U.S. Geological Survey (USGS), in cooperation with the Arkansas Natural Resources Commission (ANRC) and the Arkansas Geological Survey, has monitored water levels in the Sparta Sand of Claiborne Group and Memphis Sand of Claiborne Group (herein referred to as "the Sparta Sand" and "the Memphis Sand," respectively) since the 1920s. Groundwater withdrawals generally have increased while water levels generally have declined since monitoring was initiated. Since 1980, the USGS has produced reports, at various intervals, that describe groundwater conditions in the Sparta Sand and Memphis Sand aquifers in Arkansas. These reports are the products of a continuing project that includes the USGS groundwater monitoring effort for the State of Arkansas to provide information for management of this valuable resource.

The study area (fig. 1) in Arkansas is bounded on the north by the Missouri State line, on the east by the Tennessee and Mississippi State lines, and on the south by the Louisiana State line. The western boundary is defined as the western extent of the outcrop and subcrop (Hosman, 1982) of the Sparta Sand and the Memphis Sand. The Sparta Sand and Memphis Sand underlie the physiographic provinces of the Mississippi Alluvial Plain and the West Gulf Coastal Plain of

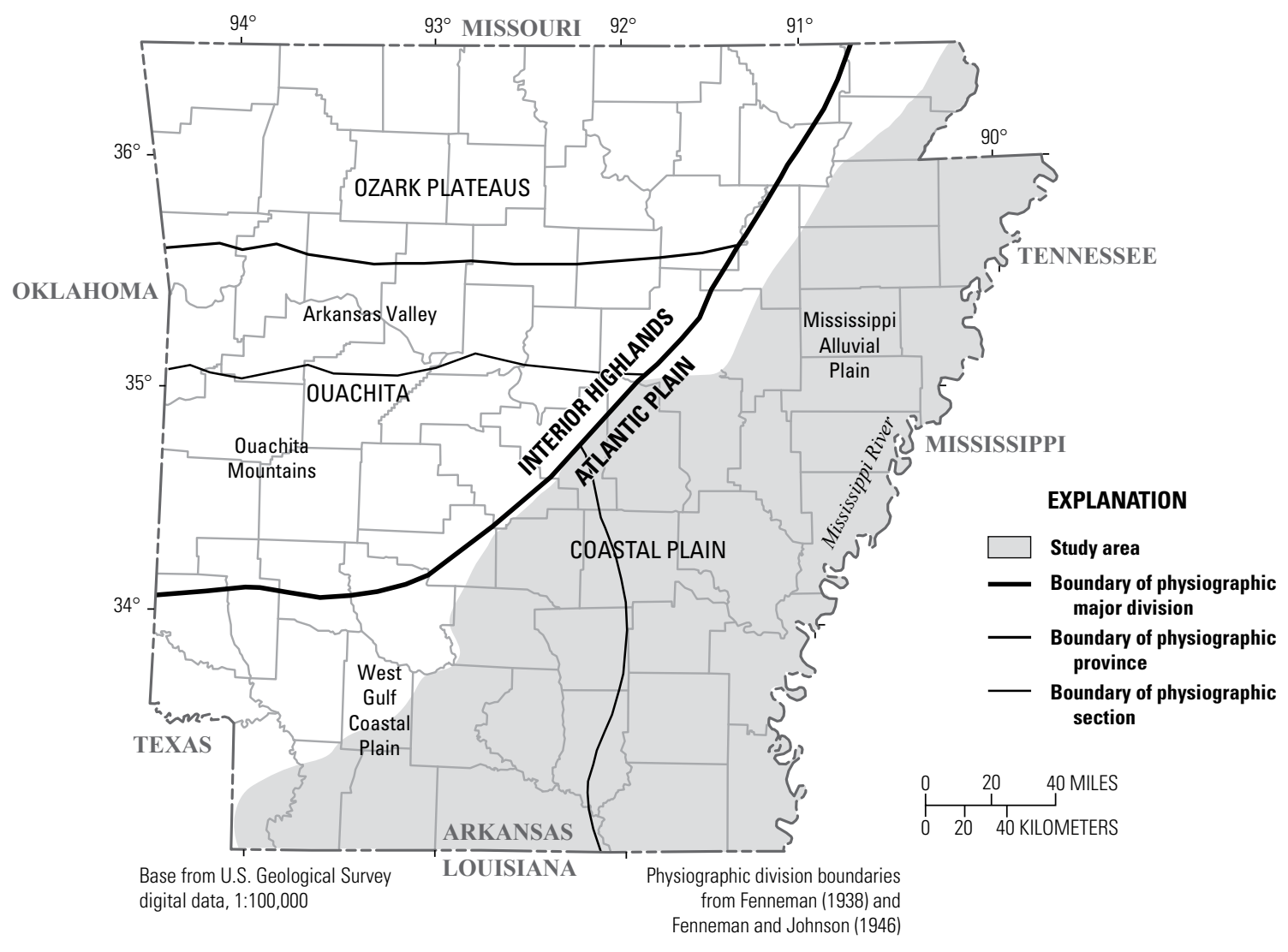

Figure 1. Location of study area. 
the Coastal Plain physiographic division (Fenneman, 1938; Fenneman and Johnson, 1946). The Sparta Sand and Memphis Sand (Eocene) are a sequence of alternating marine and continental deposits (Hosman and Weiss, 1991). Water levels in the aquifer in the Sparta Sand generally correlate with those in the aquifer in the Memphis Sand; therefore, the waterbearing formations are considered to be one hydrologic unit (Stanton, 1997).

\section{Purpose and Scope}

This report presents water-level and water-quality conditions in the aquifers in the Sparta Sand and the Memphis Sand in Arkansas. Herein, aquifers in the Sparta Sand and Memphis Sand will be referred to as "the Sparta-Memphis aquifer." Groundwater levels were measured in the spring of 2011 in 291 wells completed in the Sparta-Memphis aquifer. These measurements were used to describe the potentiometric surface of the Sparta-Memphis aquifer. During the summer of 2011, groundwater-quality samples were collected and measured from 61 wells for specific conductance, $\mathrm{pH}$, and temperature. Information in this report includes (1) groundwater levels for spring 2011, (2) a potentiometricsurface map, (3) a water-level difference map comparing water levels from 2007 to 2011, (4) selected water-level hydrographs, and (5) a groundwater-quality data table for samples collected in the summer of 2011.

\section{Water Use}

Water use in the Sparta-Memphis aquifer in Arkansas generally increased from 1965 to 2000 (fig. 2). In 1965, water use in the Sparta-Memphis aquifer was about 112 million gallons per day (Mgal/d), increasing to $142 \mathrm{Mgal} / \mathrm{d}$ in 1970 , $144 \mathrm{Mgal} / \mathrm{d}$ in 1975, and $185 \mathrm{Mgal} / \mathrm{d}$ in 1980 (Halberg and Stephens, 1966; Halberg, 1972, 1977; Holland and Ludwig, 1981). In 1985, water use declined to about $157 \mathrm{Mgal} / \mathrm{d}$ (Holland, 1987). Water use in the Sparta-Memphis aquifer was about $223 \mathrm{Mgal} / \mathrm{d}$ in 1990 and $284 \mathrm{Mgal} / \mathrm{d}$ in 1995 (Holland, 1993, 1999). In 2000, water use in the Sparta-Memphis aquifer was about $287 \mathrm{Mgal} / \mathrm{d}$ (Holland, 2004), an increase of about 156 percent from 1965. In 2005, water use in the SpartaMemphis aquifer declined to about $170 \mathrm{Mgal} / \mathrm{d}$ (Holland, 2007).

The majority of water used from the Sparta-Memphis aquifer in 2005 was shared among three primary categoriesirrigation, public supply, and industrial. Irrigation used about $61.0 \mathrm{Mgal} / \mathrm{d}$ (35.9 percent), public supply used about $58.9 \mathrm{Mgal} / \mathrm{d}$ (34.6 percent), and industrial used about 48.0 $\mathrm{Mgal} / \mathrm{d}$ (28.2 percent). Agriculture and power generation each accounted for less than 1 percent of the water use in the Sparta-Memphis aquifer in Arkansas in 2005. The agriculture category includes all farm use except domestic use for a home and irrigation. Major pumping centers that use the Sparta-Memphis aquifer for public supply and industry

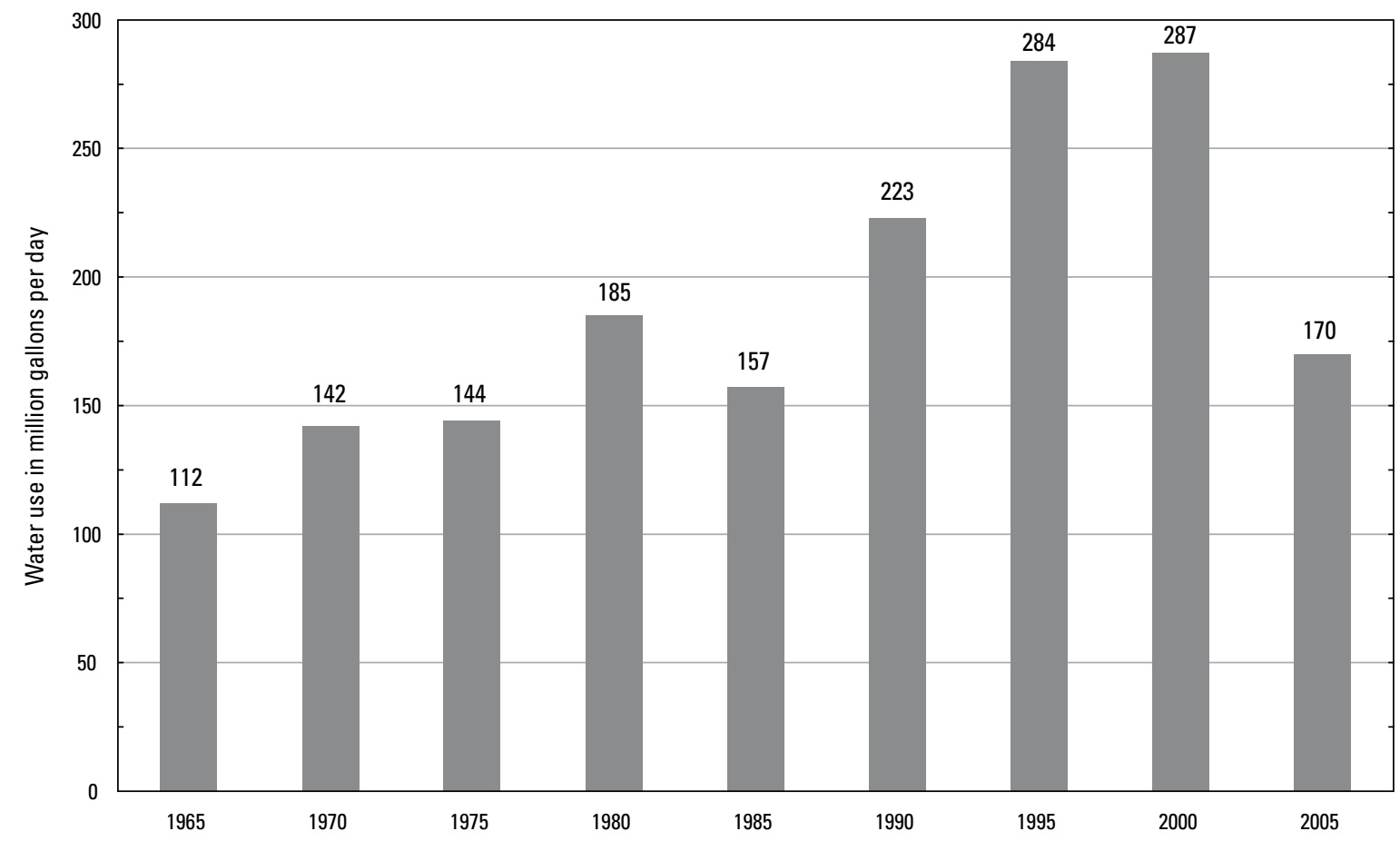

Figure 2. Water use in the Sparta-Memphis aquifer in Arkansas, 1965-2005. 
occur in Columbia, Jefferson, and Union Counties. Arkansas, Craighead, Cross, Desha, Lonoke, Monroe, Phillips, and Prairie Counties accounted for the majority of the water withdrawn for irrigation from the Sparta-Memphis aquifer in 2005 (Holland, 2007).

\section{Well-Numbering System}

The well-numbering system used in this report is based upon the Public Land Survey System used in Arkansas. The component parts of a well number are the township designation; the range designation; the section number; three-letter designation that indicates, respectively, the quarter section, the quarter-quarter section, and the quarter-quarterquarter section in which the well is located; and the sequence number of the well in the quarter-quarter-quarter section. The letters are assigned counterclockwise, beginning with "A" in the northeast quarter or quarter-quarter or quarter-quarterquarter section in which the well is located. For example, well 01S03W04BBD16 (fig. 3) is located in Township 1 South, Range 3 West, in the southeast quarter of the northwest quarter of the northwest quarter of section 4 . This well is the 16th well in this quarter-quarter-quarter section of section 4 from which data were collected.

\section{Methods}

Water levels were measured by USGS and ANRC personnel from March to May 2011 from wells completed in the Sparta-Memphis aquifer. Measurements were made using steel or electric tapes graduated in hundredths of a foot. Water levels were collected according to USGS procedural documentation (Cunningham and Schalk, 2011). The steel and electric tapes were calibrated prior to collecting water-level measurements. Calibration was performed by comparing the steel or electric tapes to a standardized steel tape used only for calibration. Tape calibrations are performed annually.

Well locations were verified using Global Positioning System (GPS) receivers to acquire the horizontal-coordinate information, latitude and longitude, based on the North American Datum of 1983. The latitude and longitude of the wells in Arkansas were recorded from a GPS receiver accurate to one-tenth of a second of latitude and longitude (approximately 10-20 feet [ft]). The latitude and longitude of each well were transferred to topographic maps and the altitude of each well (National Geodetic Vertical Datum of 1929 [NGVD 29]) was determined from the topographic contours at the location on the map. Altitude is accurate to about 2.5 to $5 \mathrm{ft}$, or half the contour interval on the map.

Two methods are used for calculating the annual rise or decline of water levels. One method is to take the difference between the final and initial water levels and divide by the period of time. This method uses two measurements, and calculated values are dependent solely on the final and initial water levels. A second method uses the linear regression of water levels and time of measurement to calculate the annual rise or decline of water levels. Linear regression is more robust because all measurments are included to determine the trend line, resulting in a value that is dependent on all water levels during the period of record. The slope, $\beta$ (equation 1), of the line is the annual rise or decline of water levels. The intercept, $\beta_{0}$, is the water level in the year 1900 , the origin for the graph. The predevelopment water level will not be discussed as this condition cannot be demonstrated. The equation of the regression line or line of best fit, $\mathrm{Y}=\mathrm{aX}+\mathrm{b}$, may be written as:

$$
h=\beta t+\beta_{0}
$$

where

$$
\begin{array}{cl}
h & \text { is water-level altitude, in feet; } \\
\beta & \text { is the slope of the line, in feet per year; } \\
t & \text { is time, in years; and } \\
\beta_{0} & \text { is the y-intercept or water-level altitude at } \\
& \text { time equal to the year 1900. }
\end{array}
$$

Five assumptions are associated with linear regression: (1) $\mathrm{Y}$ is linearly related to $\mathrm{X}$, (2) data used to fit the linear regression are representative of data of interest, (3) variance of the residuals is constant and does not depend on $\mathrm{X}$ or on anything else, (4) the residuals are independent, and (5) the residuals are normally distributed. The assumption of a normal distribution is involved only when testing hypotheses, requiring the residuals from the regression equation to be normally distributed (Helsel and Hirsch, 1992).

The $\mathrm{R}^{2}$ term is the coefficient of determination, the correlation coefficient, or the fraction of variance explained by the regression. The $\mathrm{R}^{2}$ value gives the proportions of the total variability that can be accounted by the independent variable (Helsel and Hirsch, 1992). Values of $\mathrm{R}^{2}$ can range from 0.00 to 1.00. A large value of $R^{2}$ can indicate a linear change in water level. A low value of $\mathrm{R}^{2}$ can indicate a sporadic change in water level.

Water-quality samples were collected for specific conductance, $\mathrm{pH}$, and temperature using the procedures described in the "National Field Manual for the Collection of Water-Quality Data" (U.S. Geological Survey, variously dated). Wells were purged a minimum of three casing volumes, at a pumping rate that ranged from 100 to 500 gallons per minute (Fishman and Friedman, 1989). The purge process is important to obtain a water-quality sample that is representative of the aquifer conditions without the effects of the borehole environment. Casing volumes for the wells were calculated from the well casing diameter, depth to water, and well depth. The cross-sectional area of the casing was calculated from the casing diameter, and the height of the water column was determined by subtracting the depth to water from the well depth. The cross-sectional area and the height of the water column were multiplied for a casing volume in cubic feet and converted to gallons. The calculated purge volume at each well was then divided by the pumping rate to determine the minimum pumping time for purging. 


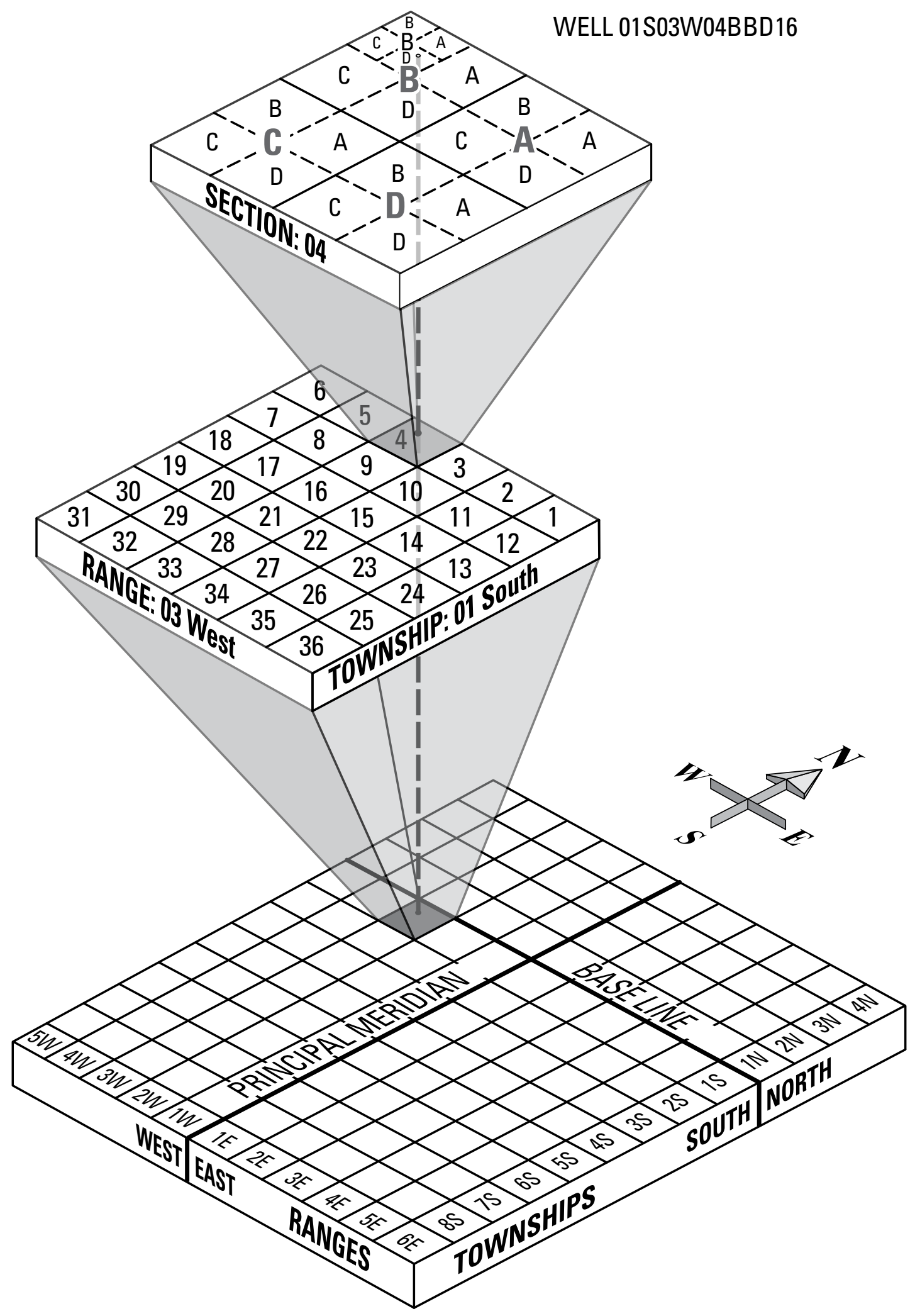

Figure 3. Diagram showing well-numbering system. 
During the purge process, specific conductance, $\mathrm{pH}$, and temperature were measured from selected wells until measurements stabilized (Fishman and Friedman, 1989), by using specific-conductance and $\mathrm{pH}$ meters with temperature compensation. A field meter was calibrated twice daily by comparing the measurement of two specific conductance and $\mathrm{pH}$ calibration standards. Specific conductance is a measure of the electrical conductance of a solution normalized to 25 degrees Celsius $\left({ }^{\circ} \mathrm{C}\right)$, an indicator of the presence of charged ionic species or dissolved solids. As the ion concentration increases in groundwater, the conductivity of the groundwater increases. The $\mathrm{pH}$ is a measure of the acidity of the water, an indicator of the hydrogen ion concentration and activity (Hem, 1985).

\section{Sparta-Memphis Aquifer}

In Arkansas, the Sparta Sand and Memphis Sand (table 1) of Eocene age mainly consist of fine to medium sand with some silt, clay, and lignite in the upper parts. Sands in the Sparta Sand were deposited by shifting streams on a deltaicfluvial flood plain (Payne, 1968). These sands mostly are interconnected, but separately identifiable sands can be traced for short distances (Snider and others, 1972). The Cook Mountain Formation of Claiborne Group overlies the Sparta Sand and Memphis Sand and serves as an upper confining unit (table 1). The permeable units of the Sparta Sand and the Memphis Sand compose the Sparta and Memphis aquifers.

The Sparta Sand is composed of a sequence of alternating sand and clay beds between the massive clays of the overlying Cook Mountain Formation and the underlying Cane River Formation of Claiborne Group confining units (Hosman and others, 1968) (table 1). The Sparta Sand is in the southern part of the study area (south of about 35 degrees latitude, pl. 1) where the Cane River Formation is composed predominantly of clay. The Memphis Sand is in the northern part of the study area (north of about 35 degrees latitude) where the Cane River
Formation or equivalent facies is composed predominantly of sand. Moving south to north in the area, the Cane River Formation undergoes a facies change northward at about 35 degrees latitude, and the marine clays become sand. The transitional zone of interfingering sands and clays is narrow. The northern sand facies of the Cane River Formation is the middle part of the Memphis Sand (Hosman and others, 1968). In the southern area, the Claiborne Group is subdivided into the Carrizo Sand, Cane River Formation, Sparta Sand, Cook Mountain Formation, and the Cockfield Formation (table 1). The equivalent section in the northern area is subdivided into the Memphis Sand, the Cook Mountain Formation, and the Cockfield Formation. The Memphis Sand in the northern area is equivalent to the Carrizo Sand, the Cane River Formation, and the Sparta Sand in the southern area. The Memphis Sand is underlain by a thick layer of clay in the upper part of the Wilcox Group (Hosman and others, 1968). The Mississippi River Valley Alluvium is the surficial aquifer in the Mississippi Alluvial Plain province (fig. 1). The Mississippi River Valley Alluvium is up to $250 \mathrm{ft}$ thick and overlies the Jackson Group. The Jackson Group overlies the Claiborne Group. In the northern half of the area, the Jackson Group may be missing, having been eroded away, and the Mississippi River Valley alluvial aquifer can be directly connected to the Memphis Sand (Schrader, 2010).

There are variations in the thickness of the Sparta Sand. Within the outcrop area (along the western limit), the Sparta Sand is 50 to $200 \mathrm{ft}$ and thickens easterly to nearly $900 \mathrm{ft}$. The Memphis Sand subcrops beneath other formations in the study area and thickens easterly to more than $900 \mathrm{ft}$ (Petersen and others, 1985). The Memphis Sand and Sparta Sand contain freshwater throughout most of their extent in Arkansas; however, saltwater is present in the extreme southeastern part of the State in parts of Ashley, Chicot, and Union Counties (Payne, 1968). The Sparta Sand and Memphis Sand generally thicken and groundwater increases in salinity as depth increases to the southeast.

Table 1. Stratigraphic correlation in the northern and southern parts of Arkansas.

[Table constructed from Petersen and others (1985); Hart and others (2008); confining units shaded in grey]

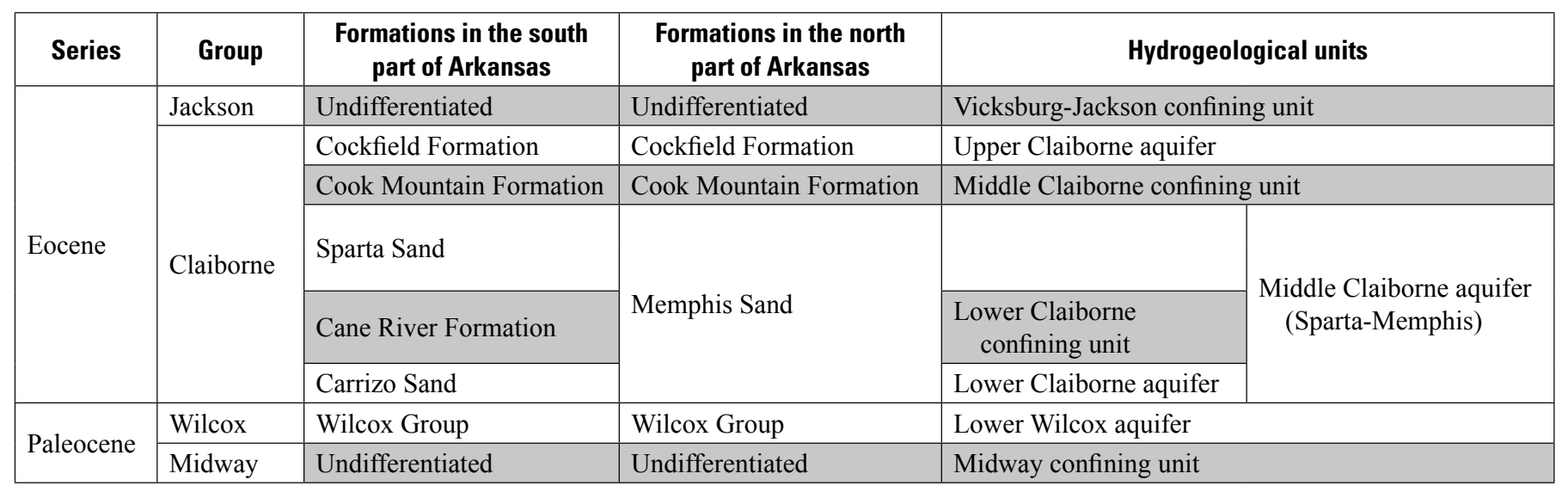




\section{Water Levels}

Water-level measurements in wells screened in the Sparta-Memphis aquifer (appendix 1) were used to produce a regional potentiometric-surface map (pl. 1), a map showing the area enclosed in 2011 by a depression in southern Arkansas for comparisons to depression areas from recent years (fig. 4), water-level difference map (pl. 2), and hydrographs (fig. 5). Water levels measured during the spring of 2011 were used to construct a potentiometric-surface map (pl. 1), then subtracted from water levels measured during the spring of 2007 at selected Sparta-Memphis aquifer wells and used to create the water-level difference map (pl. 2). Hydrographs were generated for 183 wells (that have water-level measurements with a minimum 25-year period of record) and compiled by county; hydrographs for 25 of the wells are shown in figure 5 . The water levels shown in the hydrographs indicate long-term changes in hydrologic conditions. Long-term water-level declines shown in the hydrographs reflect the response of the groundwater-flow system to stresses caused by groundwater pumping.

\section{Potentiometric-Surface Map}

A potentiometric-surface map was constructed by using 291 water-level measurements (appendix 1) from wells completed in the Sparta-Memphis aquifer during spring 2011. Hydrologic principles, water-use data, and historical information were used in conjunction with the water-level data to delineate the potentiometric-surface contours. The number and location of wells used to construct potentiometric-surface maps differ from year to year.

The potentiometric-surface map of the Sparta-Memphis aquifer shows the altitude at which water would have stood in tightly cased wells completed in the aquifer (pl. 1). The surface is mapped by determining the altitude of the water levels measured in the wells and is represented on the map by contours that connect points of equal water-level altitude. The general direction of groundwater flow in the Sparta-Memphis aquifer is perpendicular to the contours in the direction of decreasing hydraulic gradient.

In the northern half of Arkansas, the regional direction of groundwater flow in the Sparta-Memphis aquifer is generally to the south-southeast and flows east and south in the southern half of Arkansas. The groundwater in the southern half of Arkansas flows away from the outcrop area except where affected by large depressions in the potentiometric surface. The direction of groundwater flow in 2011 is towards each of three large depressions. Parts of the study area not affected by these three large depressions exhibit a regional direction of groundwater flow to the east and south, away from the outcrop area. The highest water-level altitude measured in the Sparta-Memphis aquifer was $326 \mathrm{ft}$ above NGVD 29, located in Grant County in the outcrop at the western boundary of the study area; the lowest water-level altitude was $120 \mathrm{ft}$ below NGVD 29 in Union County near the southern boundary of the study area.

Depressions usually are caused by withdrawal rates that exceed recharge rates within the aquifer over an extended period of time. When a well is pumped, the water level in and around the well declines, creating a depression in the potentiometric surface. Groundwater flows toward the depression at a rate that is proportional to the slope of the depression and the transmissivity of the aquifer (Schrader and Jones, 2007). Five depressions (represented by closed contours) are located in Arkansas; three large depressions are in the following counties: Arkansas, Cleveland, Jefferson, Lincoln, and Prairie; Union; and Poinsett, Cross, St. Francis, and Woodruff. The first depression is located in Arkansas, Cleveland, Jefferson, Lincoln, and Prairie Counties in the center of the study area, the second is in Union County in the southern part of the study area, and the third is in western Cross and Poinsett Counties in the northern half of the study area. Small depressions exist in Columbia and Bradley Counties. Two large depressions, centered in Jefferson and Union Counties, are the result of large withdrawals for industrial, irrigation, or public supply. The depression centered in Jefferson County has expanded in recent years into Arkansas and Prairie Counties as a result of large withdrawals for irrigation and public supply. The lowest water-level altitude measured in this depression is approximately 20 $\mathrm{ft}$ higher in 2011 than in 2009 (Schrader, 2013). The area enclosed within the 40 -ft contour on the 2011 potentiometricsurface map has decreased in area, shifting north in Lincoln County and west in Arkansas County when compared with the 2009 potentiometric-surface map (Schrader, 2013).

The lowest water-level altitude measurement during 2011 in the center of the depression in Union County represents a rise of $79 \mathrm{ft}$ since 2003 (Schrader, 2006). The lowest waterlevel altitude measurement was $157 \mathrm{ft}$ below NGVD 29 in 2009 (Schrader, 2013), with a 37-ft rise to $120 \mathrm{ft}$ below NGVD 29 in 2011. The location of the lowest water-level altitude can vary through time. Changes in pumping rates and well efficiency can affect the location of the lowest waterlevel altitude. The lowest water-level altitude measurement in 2011 is from the same well as the lowest water-level altitude measurement in 2003. 
The depression in Union County has diminished and is roughly circular within the -60 -ft contour and encloses a smaller area than in recent years. The -60 -ft contour is shown in figure 4 for 1993, 2003, 2007, and 2011. The area enclosed within the -60 -ft contour for each year is shown in table 2. In 1993, the $-60-\mathrm{ft}$ contour enclosed 632 sqaure miles $\left(\mathrm{mi}^{2}\right)$. In 2003, the $-60-\mathrm{ft}$ contour enclosed $767 \mathrm{mi}^{2}$, an increase of 21 percent from 1993. In 2007, the -60-ft contour enclosed $699 \mathrm{mi}^{2}$, an increase of 10 percent from 1993. In 2011, the -60-ft contour enclosed $375 \mathrm{mi}^{2}$, a decrease of 41 percent from 1993. The -60-ft contour on the 2011 potentiometric-surface map has moved away from the Arkansas-Louisiana State border. The area enclosed by the lowest altitude contour, $120 \mathrm{ft}$ below NGVD 29, on the 2011 potentiometric-surface map is less than 10 percent of the area enclosed by that same contour on the 2009 potentiometric-surface map (Schrader, 2013). The lowest altitude contour on the 2009 potentiometric-surface map (Schrader, 2013), $140 \mathrm{ft}$ below NGVD 29, is not present on the 2011 potentiometric-surface map.

A broad depression, first shown in the 1995 potentiometric-surface map (Stanton, 1997), in western Poinsett and Cross Counties has both increased and decreased in size since 1995. The depression expanded in area in 1997 and 1999 and then decreased in area in 2003 and 2005. In 1997, the depression covered most of the western half of Poinsett County (Joseph, 1998). In 1999, the 150 -ft contour of the depression extended from Poinsett County through Cross County into St. Francis County (Joseph, 2000; Schrader, 2004). In 2003, the depression covered most of the western half of Poinsett County (Schrader, 2006). In 2005, the depression covered part of western Poinsett County and extended into northwestern Cross County. In 2007, the 140-ft contour expanded northeast to the
Poinsett-Craighead County line, farther east, and the farthest extent south into Cross County (Schrader and Jones, 2007). In 2009, the 140-ft contour had extended south across twothirds of Cross County. In 2011, the lowest water-level altitude measurement in this depression, $129 \mathrm{ft}$ above NGVD 29, was $2 \mathrm{ft}$ lower than in 2009. The 140-ft contour extended southwest into northwestern St. Francis and east-central Woodruff Counties in 2011.

Unlike other depressions in the Sparta-Memphis aquifer, the depression in Poinsett, Cross, St. Francis, and Woodruff Counties primarily is caused by withdrawals for irrigation, instead of withdrawals for public supply and industrial uses. The Mississippi Embayment Regional Aquifer Study project has identified an area in Poinsett, Cross, and St. Francis Counties where the Sparta-Memphis aquifer and the Mississippi River Valley alluvial aquifer (herein referred to as the "alluvial aquifer") are hydrologically connected. Borehole geophysical logs show that the Jackson Group, the unit that underlies the alluvial aquifer; the Cockfield Formation of Claiborne Group; and the Cook Mountain Formation of Claiborne Group, the unit that confines the Sparta-Memphis aquifer, are absent in this area (Hart and others, 2008). Irrigation withdrawals from the alluvial aquifer have resulted in water-level declines in the Sparta-Memphis aquifer (Schrader, 2008).

Two other depressions located in Columbia and Bradley Counties are shown on the 2011 potentiometric surface. The depression in Columbia County was first shown on the 199697 potentiometric-surface map (Joseph, 1998). In 2011, the area decreased, with water levels rising about $1 \mathrm{ft}$ since 2005 in the well with the lowest water-level altitude measurement. The depression in Bradley County was first shown in 2007 (Schrader, 2009). In 2011, this depression decreased in area.

Table 2. Area within the -60-foot contour in Union County, Arkansas in 1993, 2003, 2007, and 2011.

\begin{tabular}{ccc}
\hline Year & $\begin{array}{c}\text { Area } \\
\text { (square miles) }\end{array}$ & $\begin{array}{c}\text { Area } \\
\text { (square kilometers) }\end{array}$ \\
\hline 1993 & 632 & 1,018 \\
2003 & 767 & 1,234 \\
2007 & 699 & 1,124 \\
2011 & 375 & 604 \\
\hline
\end{tabular}




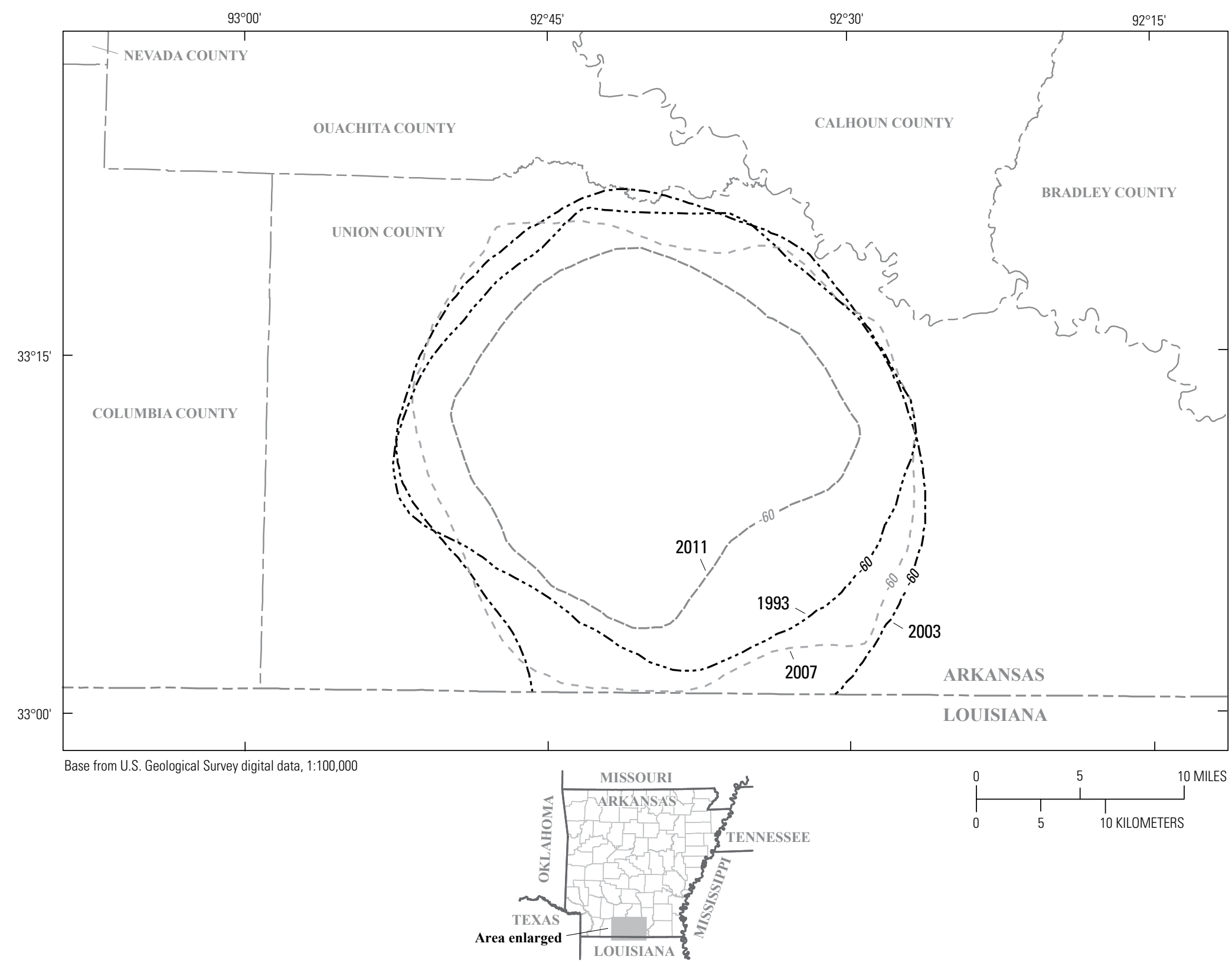

Figure 4. Change in the depression in southern Arkansas, 1993-2011. 


\section{Water-Level Difference from 2007 to 2011}

A water-level difference map (pl. 2) was constructed using the difference between water-level measurements made during 2007 and 2011 at 247 wells (appendix 2). The difference in water levels was calculated by subtracting the 2011 depth-to-water level from the 2007 depth-to-water level. Positive values shown on plate 2 indicate a rise, and negative values indicate a decline in water level. Rises in water level are indicated on plate 2 with blue triangles pointing upward; declines in water level are indicated with red triangles pointing downward. Triangles are scaled to the relative value of the rise or decline. Water-level differences do not necessarily indicate a long-term water-level trend but are intended to show where water levels have increased or decreased from 2007 to 2011.

The differences in water levels between 2007 and 2011 ranged from -17.3 to $45.4 \mathrm{ft}$, with a mean of $4.1 \mathrm{ft}$. The largest measured decline $(-17.3 \mathrm{ft})$ in water level was in eastern Union County. The largest measured rise (45.4 ft) in water level was in central Union County. In central Union County (pl. 2), water levels in seven wells rose $20 \mathrm{ft}$ or more, with an average annual rise of $5 \mathrm{ft}$ or more. The rising water levels in central Union County coincide with water conservation measures initiated in 1999 and the conversion of large industrial water users from groundwater to surface water from the Ouachita River beginning in December 2004 (Scheiderer and Freiwald, 2006).

Water levels generally declined in the northern half of the study area and generally increased in the southern half of the study area. Areas with a general decline in water levels include Lonoke and western Prairie Counties; northern Arkansas County; Miller County; and Craighead, Poinsett, Cross, and Woodruff Counties. Areas with a general rise in water levels include Lafayette, Columbia, Union, Calhoun, and Bradley Counties; Grant, Jefferson, southern Arkansas, Lincoln, Drew, and Desha Counties; and Phillips County (pl. 2).

\section{Long-Term Hydrographs}

Hydrographs from 183 wells with a minimum of 25 years of water-level measurements were constructed. Selected hydrographs are shown in figure 5 with locations indicated on plate 1 . The minimum 25 -year period of record is used to evaluate long-term trends not dominated by variations in climate and localized pumping rates on water levels in a single well. A trend line using linear regression was calculated for the period from 1987 to 2011 to determine the slope in feet per year (ft/yr) for water levels in each well. The slope of the trend line represents the typical annual decline or rise in water level during the 25-year period. A statistical summary of the number of wells; the range, mean, and median of the annual rise or decline in water level; and the range of the $\mathrm{R}^{2}$ values for each county are listed in table 3 . Negative values denote a decline in water level. During the period 1987-2011, county mean annual water levels generally declined. Mean annual declines were between $0.5 \mathrm{ft} / \mathrm{yr}$ and $0.0 \mathrm{ft} / \mathrm{yr}$ in Ashley, Chicot, Crittenden, Drew, Grant, Jefferson, Lafayette, Mississippi, Monroe, Ouachita, Phillips, Pulaski, St. Francis, and Woodruff Counties (table 2). Mean annual declines were between $1.0 \mathrm{ft} / \mathrm{yr}$ and $0.5 \mathrm{ft} / \mathrm{yr}$ in Bradley, Calhoun, Cleveland, Craighead, Cross, Desha, Lonoke, Miller, Poinsett, and Prairie Counties. Mean annual declines were between $1.5 \mathrm{ft} / \mathrm{yr}$ and $1.0 \mathrm{ft} / \mathrm{yr}$ in Arkansas, Lee, and Lincoln Counties. The county mean annual water level rose in Columbia, Dallas, and Union Counties, about $0.3 \mathrm{ft} / \mathrm{yr}, 0.1 \mathrm{ft} / \mathrm{yr}$, and $1.2 \mathrm{ft} / \mathrm{yr}$, respectively. 
Table 3. Number of wells, range, mean, median, and correlation coefficient $\left(R^{2}\right)$ of annual rise-decline in water level by county for wells in the Sparta-Memphis aquifer, 1987-2011.

[Annual rise or decline in water level for each well is calculated using linear regression; negative value indicates decline; positive value indicates rise]

\begin{tabular}{|c|c|c|c|c|c|}
\hline County & $\begin{array}{l}\text { Number of } \\
\text { wells }\end{array}$ & $\begin{array}{l}\text { Range of annual rise- } \\
\text { decline in water level } \\
\text { (feet/year) }\end{array}$ & $\begin{array}{l}\text { Mean annual rise- } \\
\text { decline in water level } \\
\text { (feet/year) }\end{array}$ & $\begin{array}{l}\text { Median annual rise- } \\
\text { decline in water level } \\
\text { (feet/year) }\end{array}$ & $\begin{array}{l}\text { Range of } R^{2} \text { values } \\
\text { for trend line }\end{array}$ \\
\hline Arkansas & 26 & -1.42 to -0.26 & -1.02 & -1.11 & 0.14 to 0.78 \\
\hline Ashley & 6 & -0.55 to -0.04 & -0.32 & -0.38 & 0.10 to 0.87 \\
\hline Bradley & 4 & -1.35 to 0.29 & -0.68 & -0.84 & 0.23 to 0.96 \\
\hline Calhoun & 2 & -0.69 to -0.69 & -0.69 & -0.69 & 0.35 to 0.35 \\
\hline Chicot & 1 & -0.21 to -0.21 & -0.21 & -0.21 & 0.37 to 0.37 \\
\hline Cleveland & 4 & -0.99 to -0.26 & -0.66 & -0.69 & 0.19 to 0.88 \\
\hline Columbia & 13 & -1.10 to 3.07 & 0.31 & -0.07 & 0.10 to 0.93 \\
\hline Craighead & 1 & -0.80 to -0.80 & -0.80 & -0.80 & 0.80 to 0.80 \\
\hline Crittenden & 3 & -0.37 to 0.40 & -0.07 & -0.26 & 0.58 to 0.92 \\
\hline Cross & 5 & -1.10 to -0.44 & -0.85 & -0.91 & 0.54 to 0.87 \\
\hline Dallas & 8 & -0.47 to 1.72 & 0.05 & -0.11 & 0.00 to 0.95 \\
\hline Desha & 6 & -1.31 to -0.35 & -0.69 & -0.57 & 0.17 to 0.81 \\
\hline Drew & 5 & -0.80 to 0.15 & -0.40 & -0.47 & 0.11 to 0.97 \\
\hline Grant & 8 & -1.10 to -0.07 & -0.35 & -0.26 & 0.18 to 0.81 \\
\hline Jefferson & 18 & -2.52 to 7.38 & -0.31 & -1.02 & 0.11 to 0.93 \\
\hline Lafayette & 2 & -0.04 to -0.01 & -0.03 & -0.03 & 0.10 to 0.10 \\
\hline Lee & 2 & -1.39 to -0.84 & -1.11 & -1.11 & 0.86 to 0.94 \\
\hline Lincoln & 6 & -2.70 to -0.77 & -1.41 & -1.21 & 0.66 to 0.88 \\
\hline Lonoke & 5 & -1.21 to 1.17 & -0.66 & -1.10 & 0.38 to 0.99 \\
\hline Miller & 2 & -0.88 to -0.15 & -0.51 & -0.51 & 0.12 to 0.51 \\
\hline Mississippi & 1 & -0.40 to 0.40 & -0.40 & -0.40 & 0.20 to 0.20 \\
\hline Monroe & 5 & -0.95 to -0.04 & -0.35 & -0.29 & 0.15 to 0.90 \\
\hline Ouachita & 13 & -1.64 to 1.79 & -0.00 & -0.07 & 0.11 to 0.85 \\
\hline Phillips & 6 & -0.62 to 0.29 & -0.05 & -0.02 & 0.15 to 0.78 \\
\hline Poinsett & 2 & -1.17 to -0.69 & -0.93 & -0.93 & 0.40 to 0.94 \\
\hline Prairie & 10 & -1.53 to 0.62 & -0.89 & -1.06 & 0.17 to 0.96 \\
\hline Pulaski & 2 & -0.47 to -0.22 & -0.35 & -0.35 & 0.45 to 0.50 \\
\hline St. Francis & 1 & -0.11 to -0.11 & -0.11 & -0.11 & 0.16 to 0.16 \\
\hline Union & 29 & -0.95 to 8.55 & 1.17 & 0.40 & 0.11 to 0.95 \\
\hline Woodruff & 1 & -0.03 to -0.03 & -0.03 & -0.03 & 0.23 to 0.23 \\
\hline
\end{tabular}


A. ARKANSAS COUNTY, WELL 03S06W30BBD1
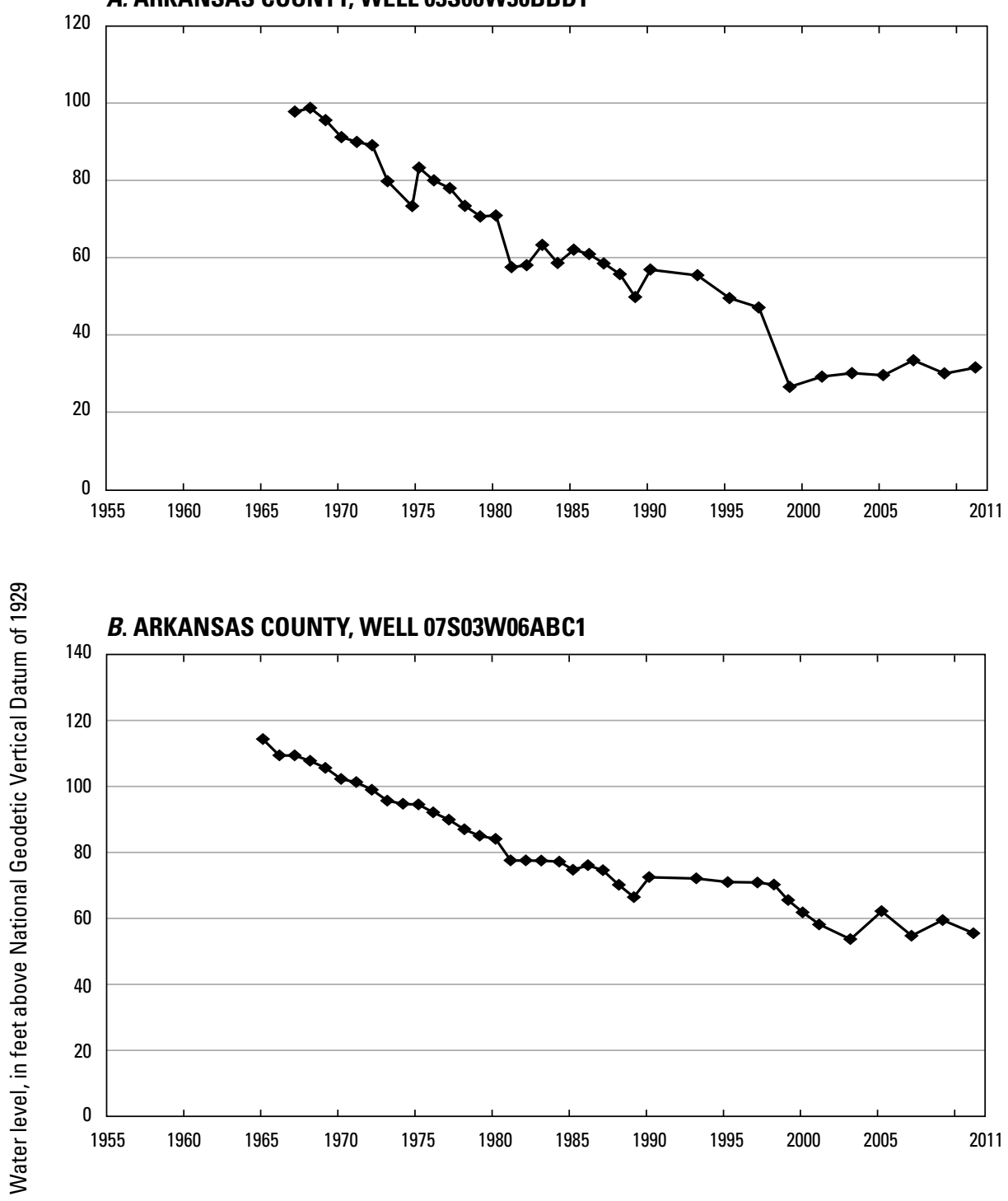

\section{ASHLEY COUNTY, WELL 15S17W32CDD1}

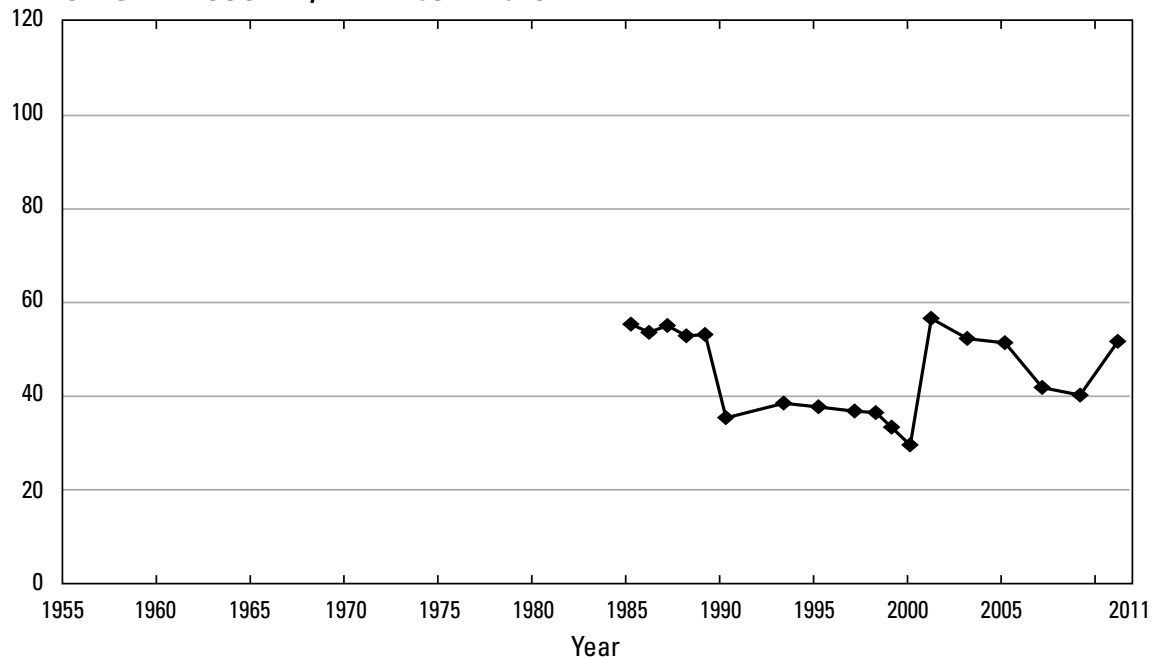

Figure 5. Water levels for selected wells completed in the Sparta-Memphis aquifer in Arkansas. 
D. BRADLEY COUNTY, WELL 13S11W17BCD1
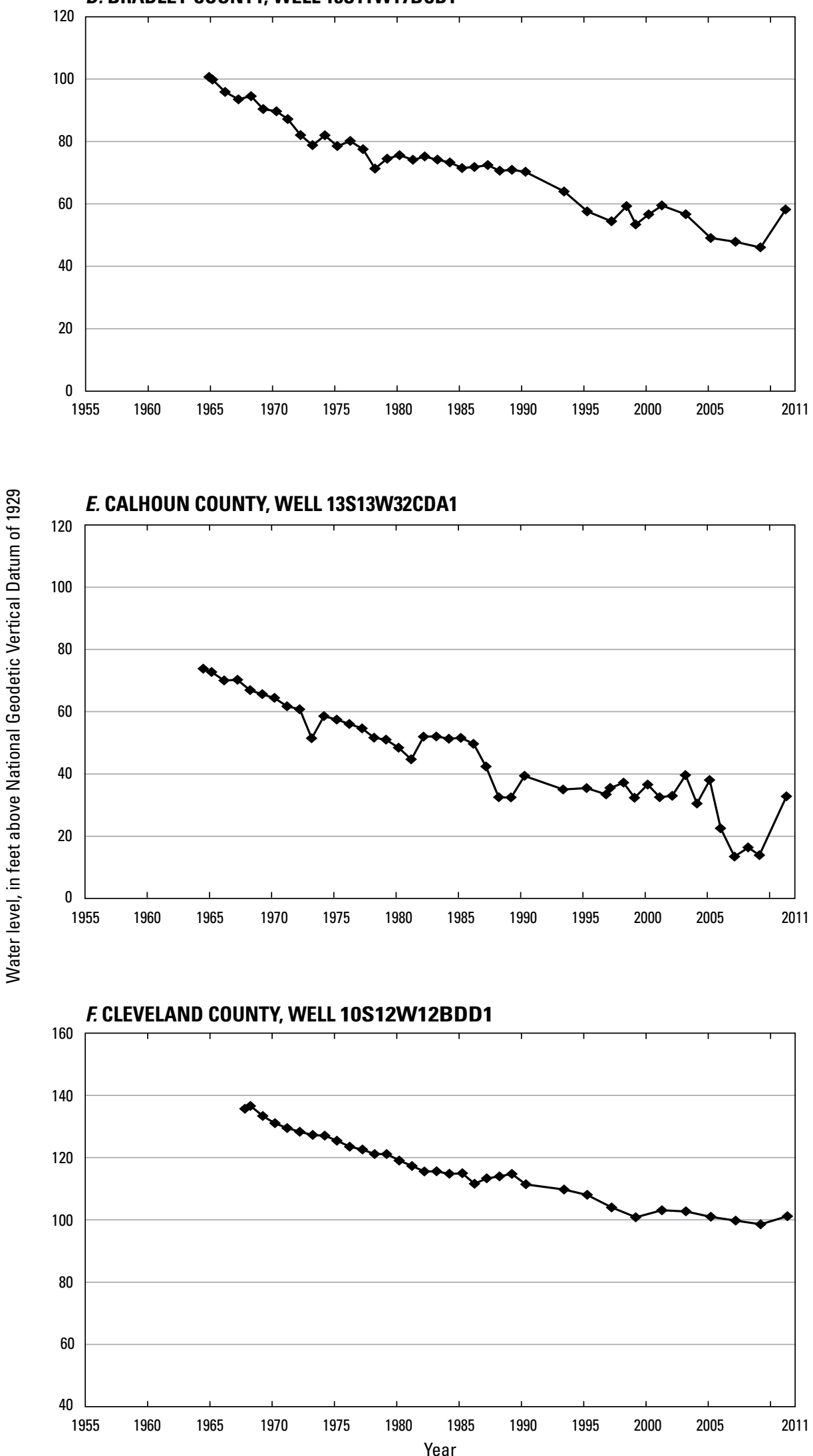

Figure 5. Water levels for selected wells completed in the Sparta-Memphis aquifer in Arkansas. - Continued 
G. COLUMBIA COUNTY, WELL 17S21W11DCC2
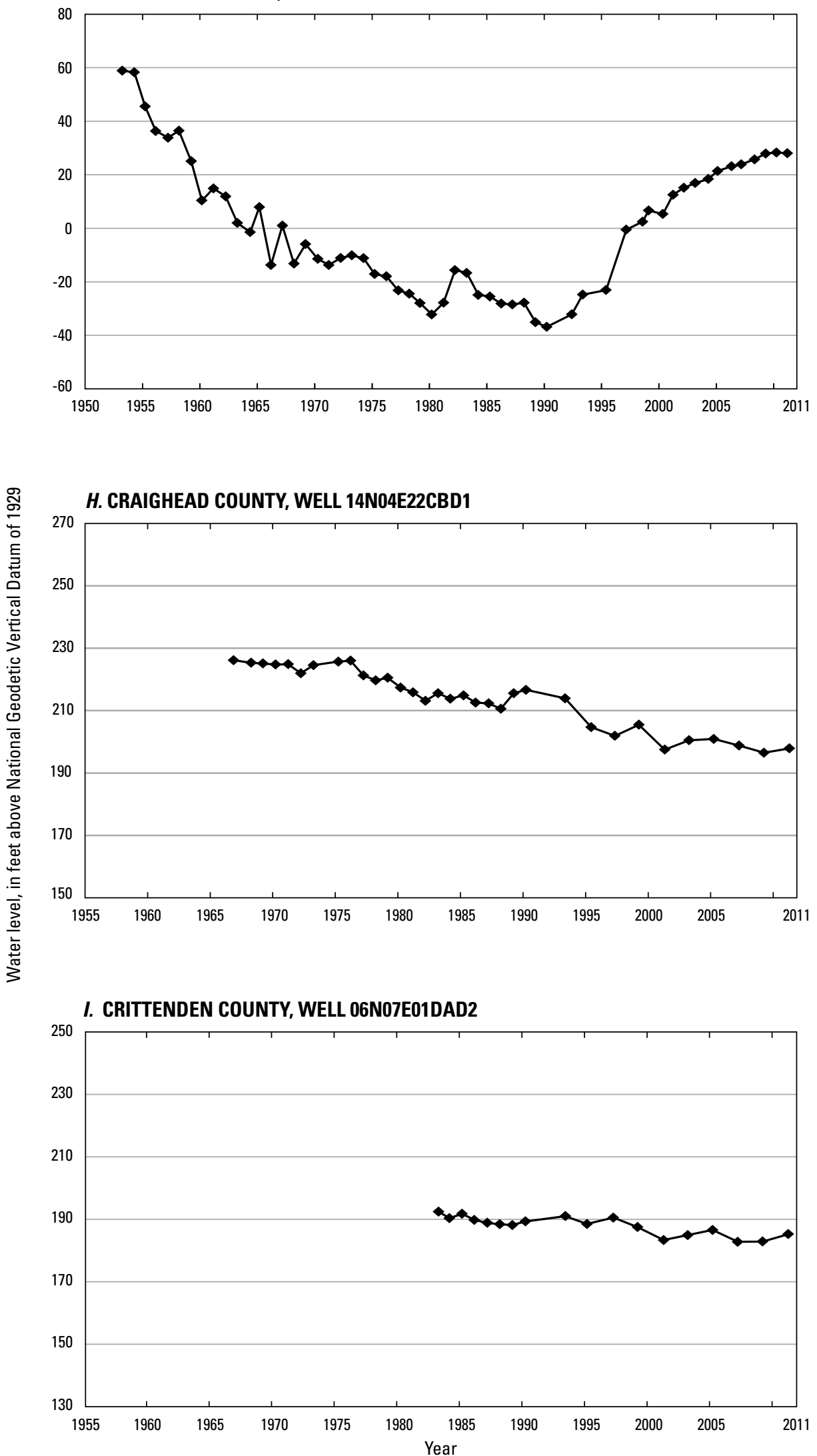

Figure 5. Water levels for selected wells completed in the Sparta-Memphis aquifer in Arkansas. - Continued 

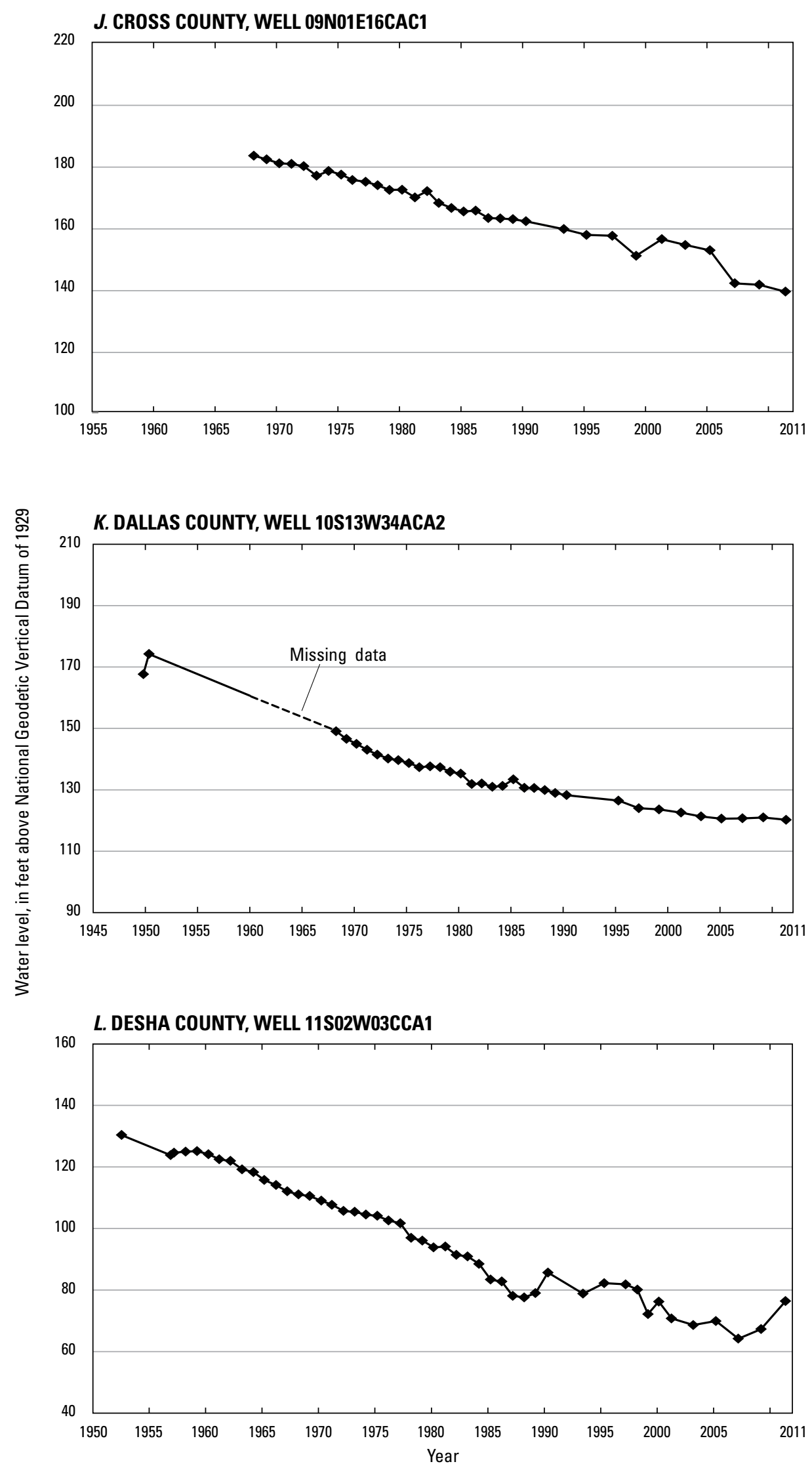

Figure 5. Water levels for selected wells completed in the Sparta-Memphis aquifer in Arkansas. - Continued 

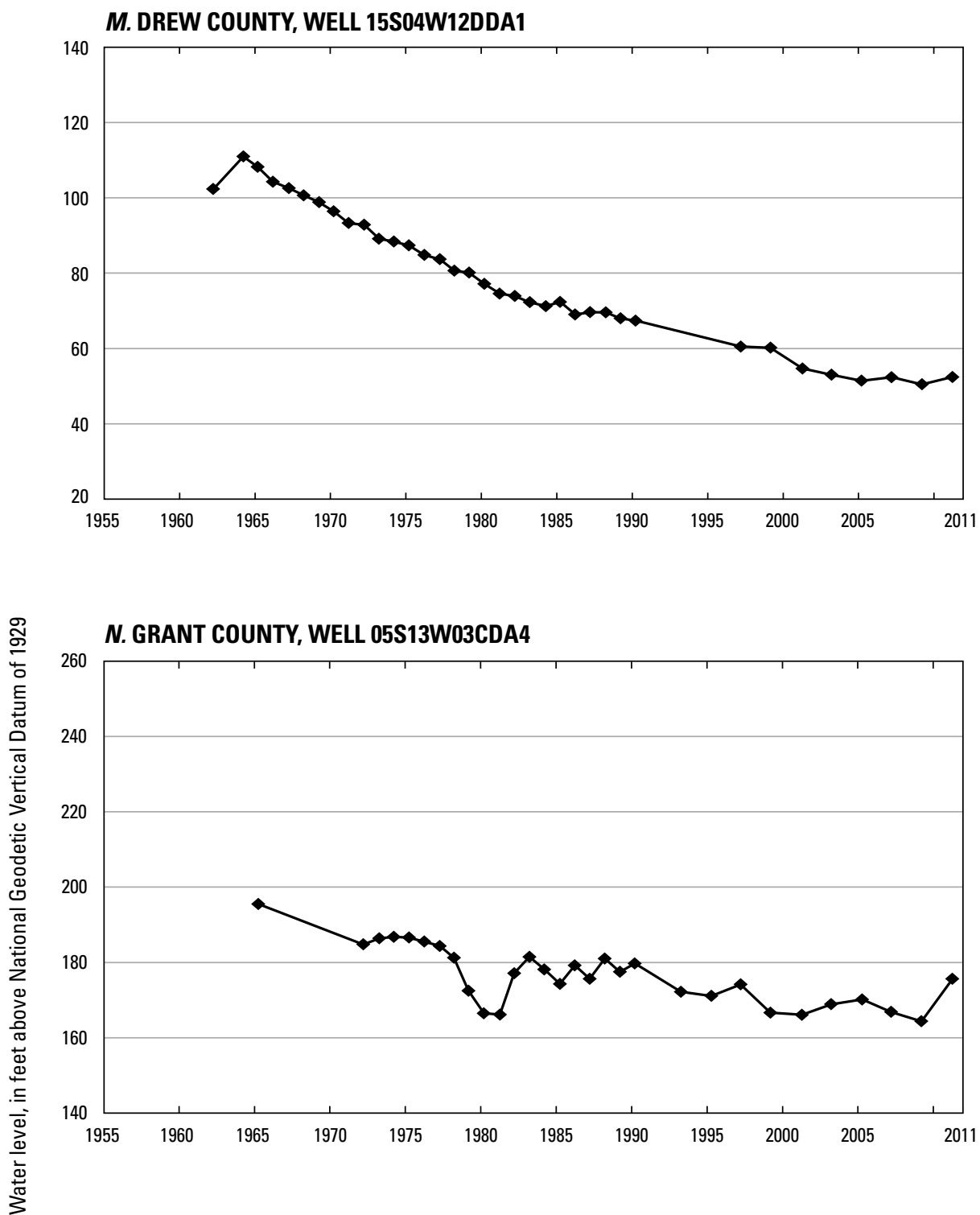

\section{O. JEFFERSON COUNTY, WELL 06S08W16CCC1}

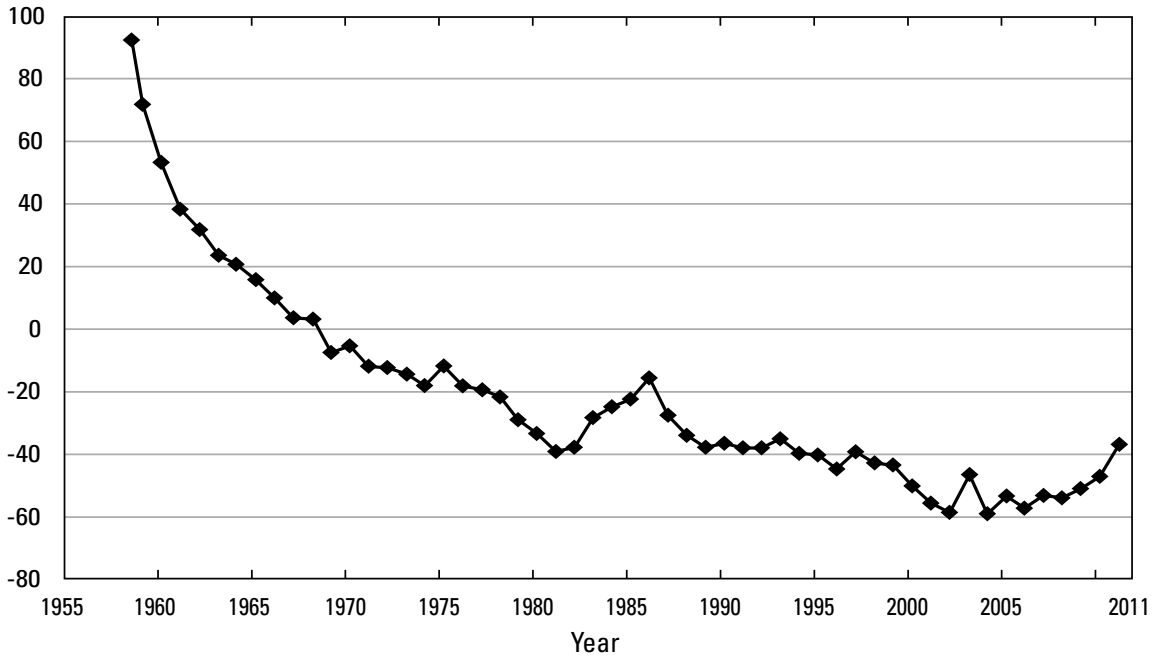

Figure 5. Water levels for selected wells completed in the Sparta-Memphis aquifer in Arkansas.-Continued 

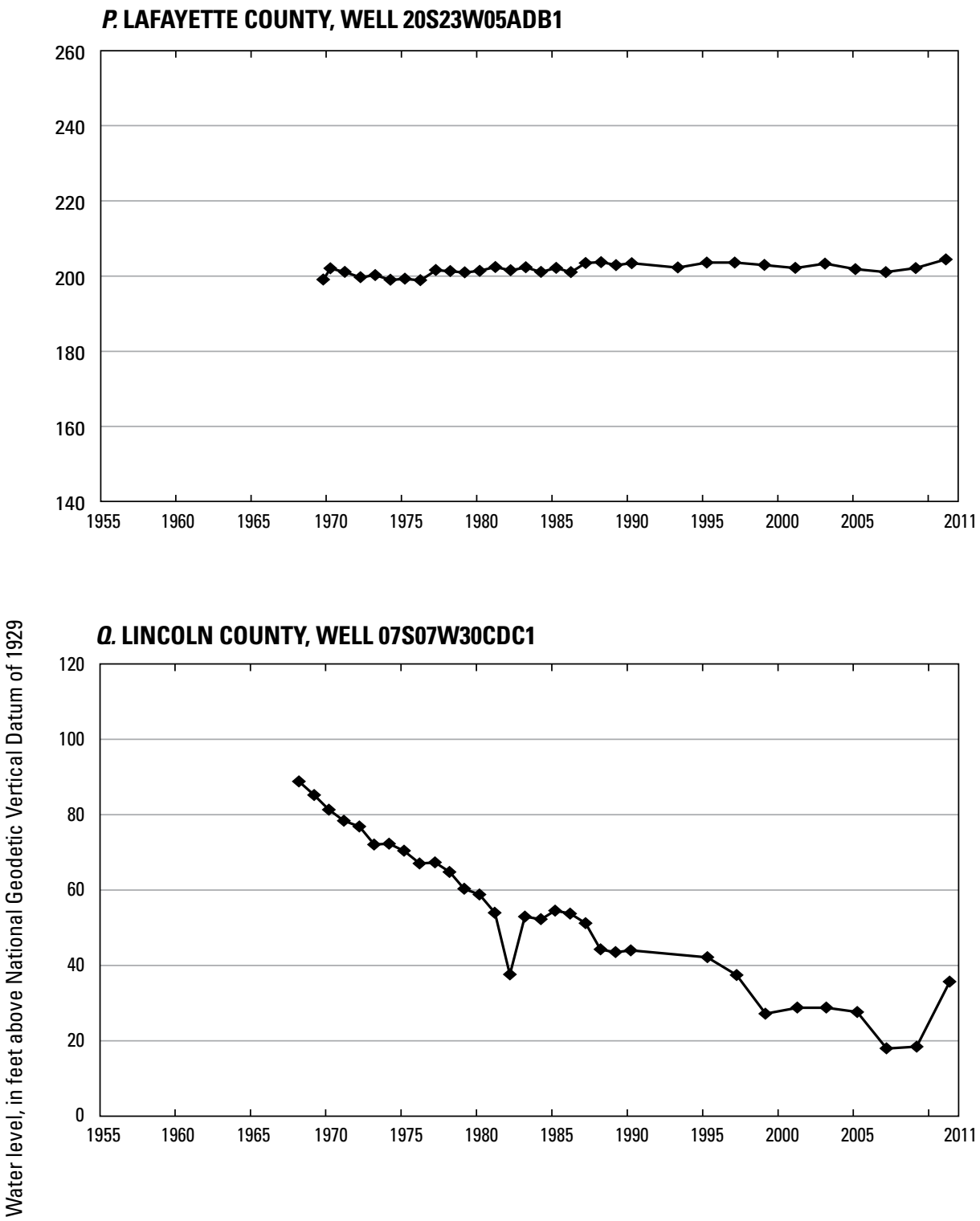

R. LONOKE COUNTY, WELL 02S08W16BDA1

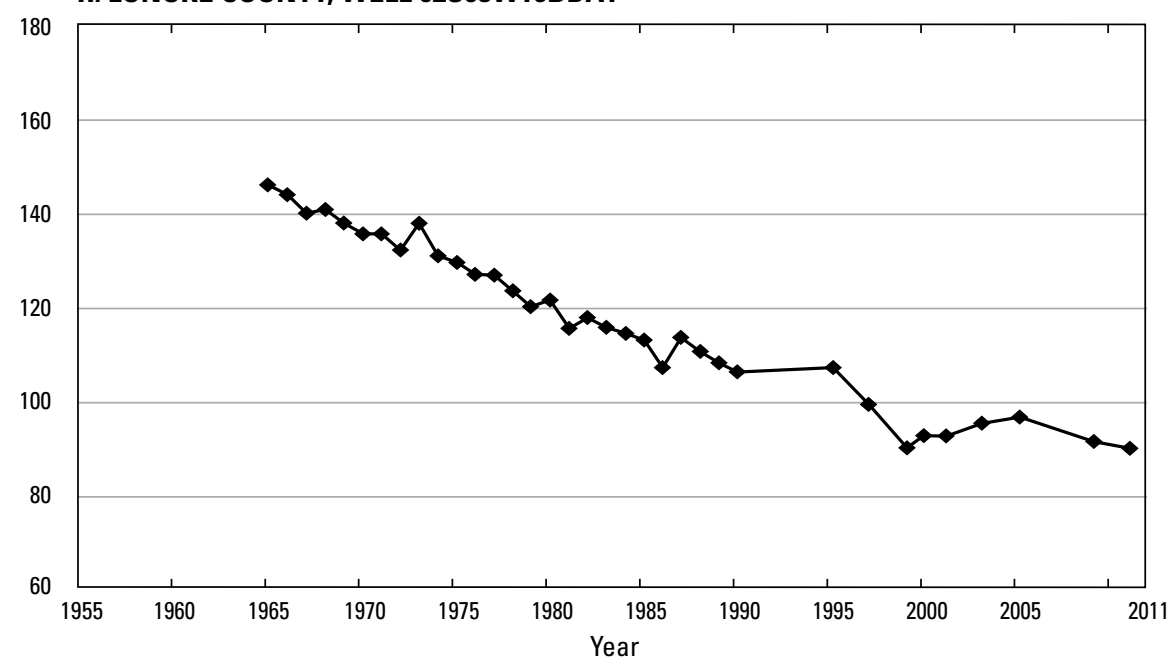

Figure 5. Water levels for selected wells completed in the Sparta-Memphis aquifer in Arkansas. - Continued 
S. MONROE COUNTY, WELL 04N02W28DDD4
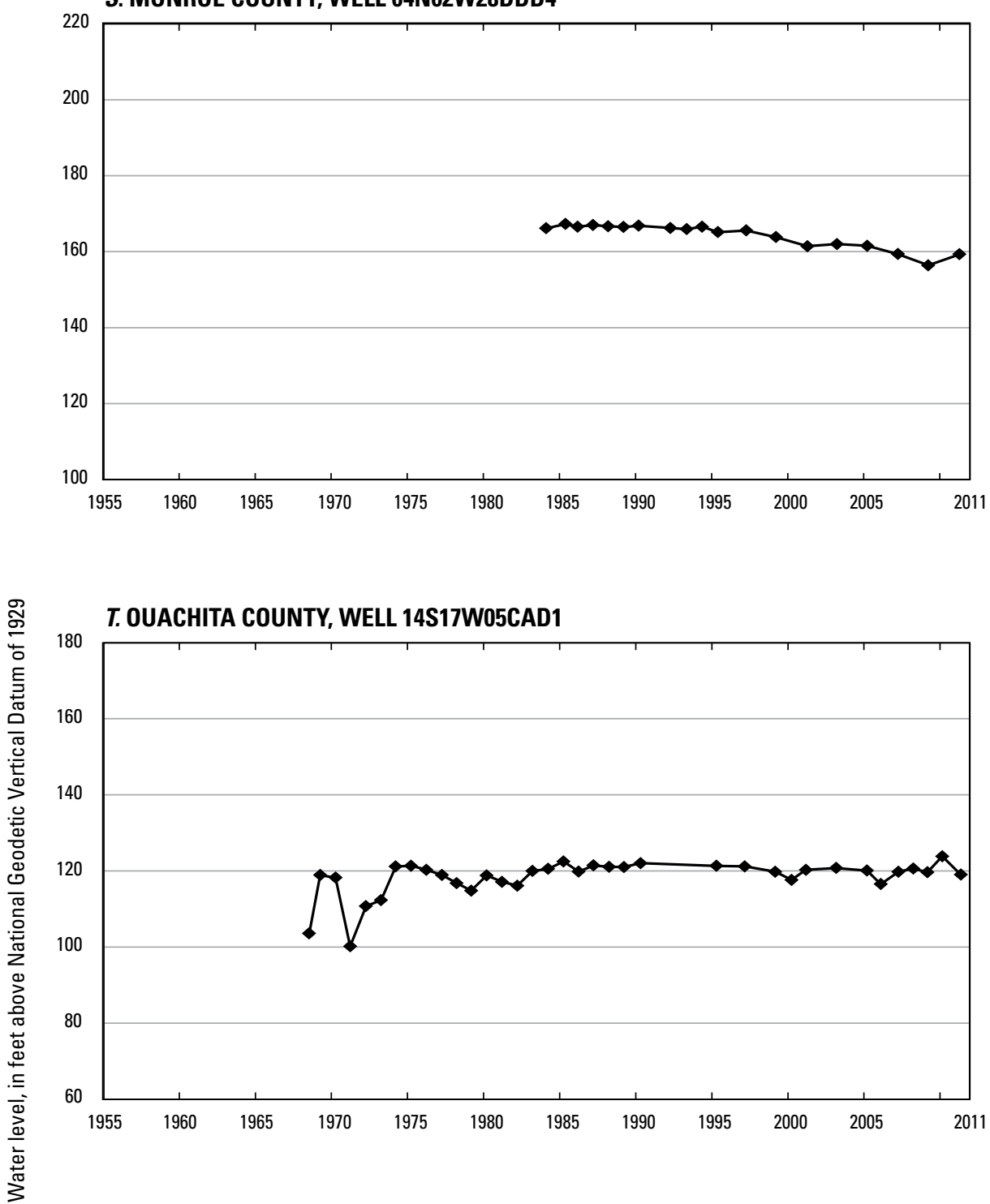

U. PHILLIPS COUNTY, WELL 01S02E32DDC1

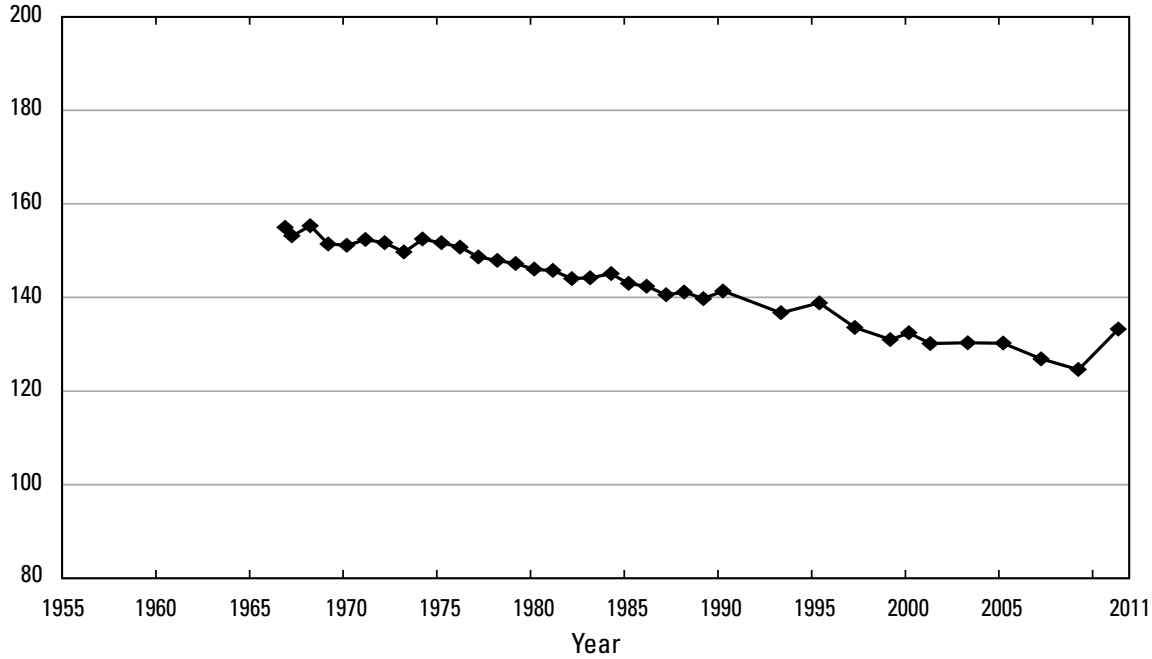

Figure 5. Water levels for selected wells completed in the Sparta-Memphis aquifer in Arkansas.-Continued 

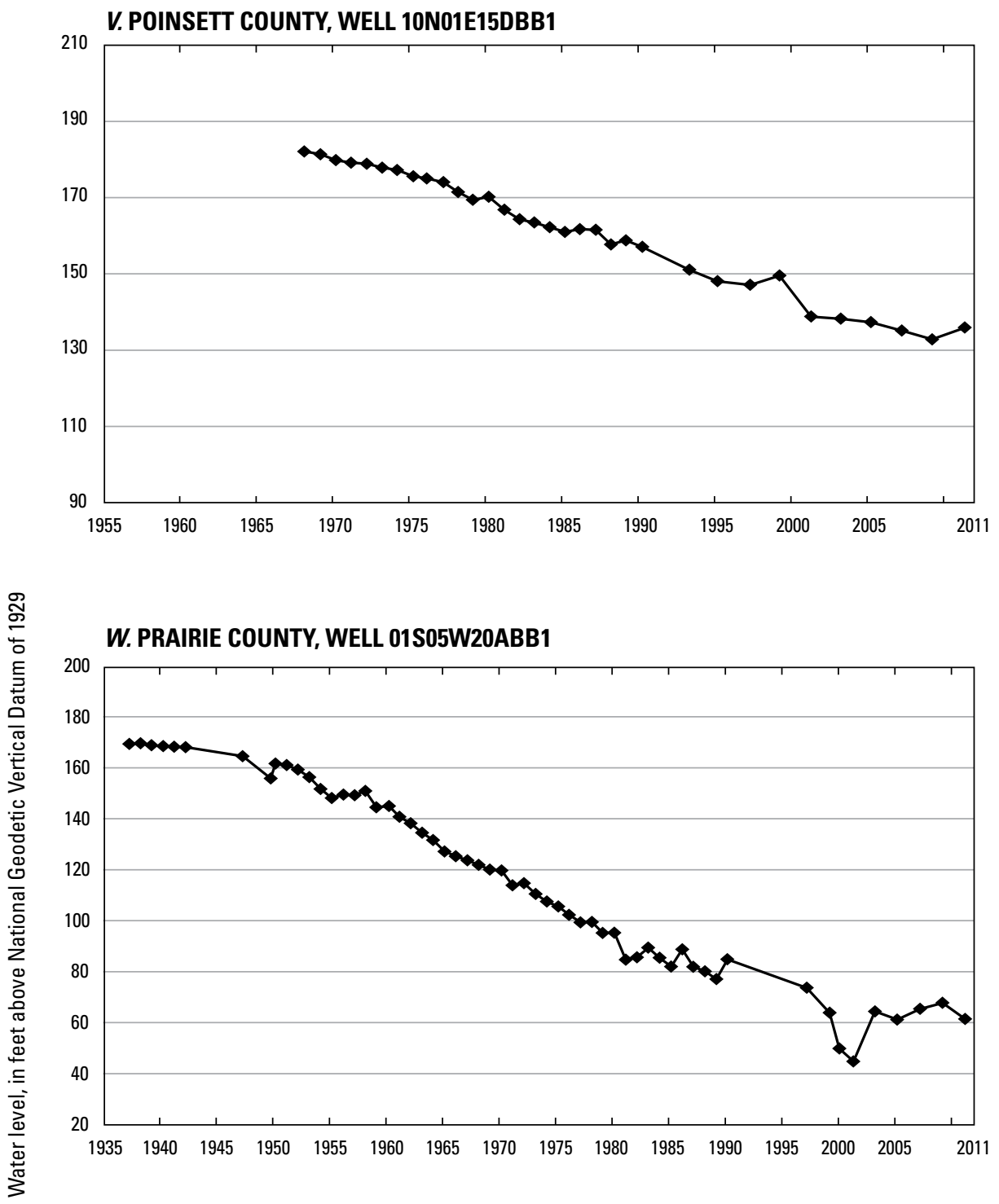

$X$. UNION COUNTY, WELL 17S15W18DBB1

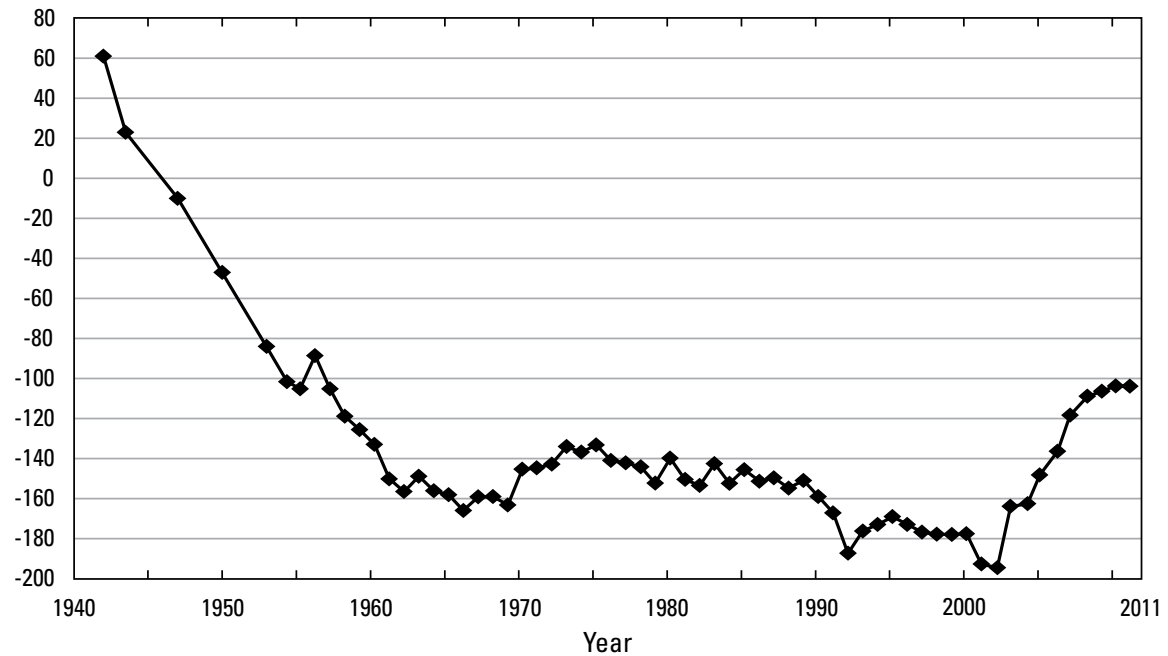

Figure 5. Water levels for selected wells completed in the Sparta-Memphis aquifer in Arkansas. - Continued 


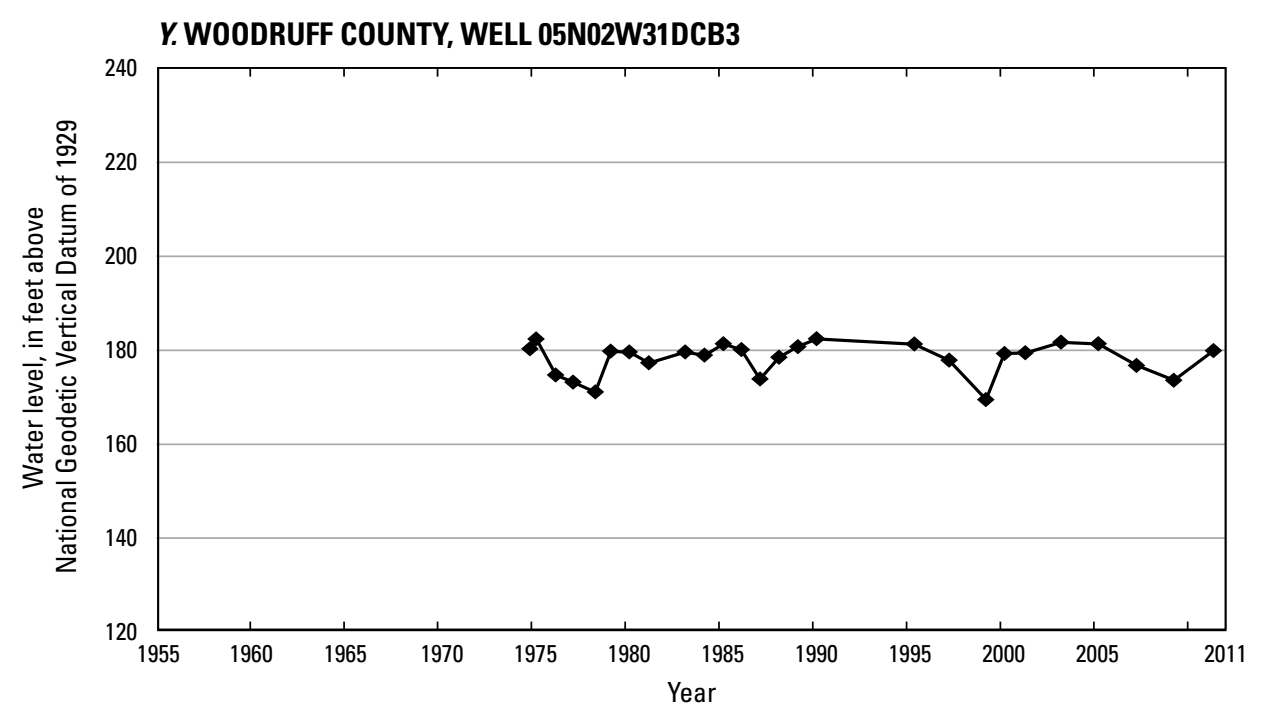

Figure 5. Water levels for selected wells completed in the Sparta-Memphis aquifer in Arkansas.-Continued

\section{Water-Quality Conditions}

Water samples were collected in the summer of 2011 from 61 wells completed in the Sparta-Memphis aquifer and measured onsite for specific conductance, $\mathrm{pH}$, and temperature (app. 3). Specific conductance ranged from 35 microsiemens per centimeter at 25 degrees Celsius $(\mu \mathrm{S} /$ $\mathrm{cm})$ in Ouachita County to $1,380 \mu \mathrm{S} / \mathrm{cm}$ in Monroe County. Relatively large specific conductance values (greater than $700 \mu \mathrm{S} / \mathrm{cm}$ ) occur in samples from wells in Arkansas, Ashley, Clay, Monroe, Phillips, and Union Counties. Large specific conductance values occur near the water-level depression (pl. 1) in Union County and increase eastward toward Ashley County; several specific-conductance values greater than $2,000 \mu \mathrm{S} / \mathrm{cm}$ for groundwater from the Sparta aquifer in Union County have been documented (Broom and others, 1984).

Although there is a regional increase in specific conductance to the east and south, anomalous increases occur in some parts of the study area. Morris and Bush (1986) and Broom and others (1984) cited upward leakage of saltwater from the Nacatoch Formation of Cretaceous age into the Sparta aquifer through a fault or abandoned oil and gas wells as possible explanations for these anomalies.
Specific conductance values from samples collected in 2009 and 2011 generally were less than $400 \mu \mathrm{S} / \mathrm{cm}$. The histograms of specific conductance data for 2009 (64 samples) (Schrader, 2013) and 2011 (61 samples) are shown in figure 6. The mean specific conductance was $392 \mu \mathrm{S} / \mathrm{cm}$ in 2009 and $391 \mu \mathrm{S} / \mathrm{cm}$ in 2011. Both histograms have a right skew. Eighty-four percent of the wells sampled in 2009 and 2011 had specific conductance values less than $600 \mu \mathrm{S} / \mathrm{cm}$. The largest category for both years is the $201-400 \mu \mathrm{S} / \mathrm{cm}$ range. The $201-400 \mu \mathrm{S} / \mathrm{cm}$ range included 53 percent of the samples in 2009 and 36 percent of the samples in 2011. The lowest range, $1-200 \mu \mathrm{S} / \mathrm{cm}$, increased from 15 percent of the samples in 2009 to 26 percent of the samples in 2011 . The small change in the mean specific conductance and the distribution of data from 2009 to 2011 may indicate a change in water quality or be the result of the distribution of sampling locations.

Temperature ranged from $18.0^{\circ} \mathrm{C}$ in Ouachita County to $26.7^{\circ} \mathrm{C}$ in Nevada County. The mean temperature was $23.0^{\circ} \mathrm{C}$. The $\mathrm{pH}$ ranged from 5.4 in Ouachita County to 8.8 in Calhoun, Drew, and Union Counties. The $\mathrm{pH}$ had a mean of 7.7. 


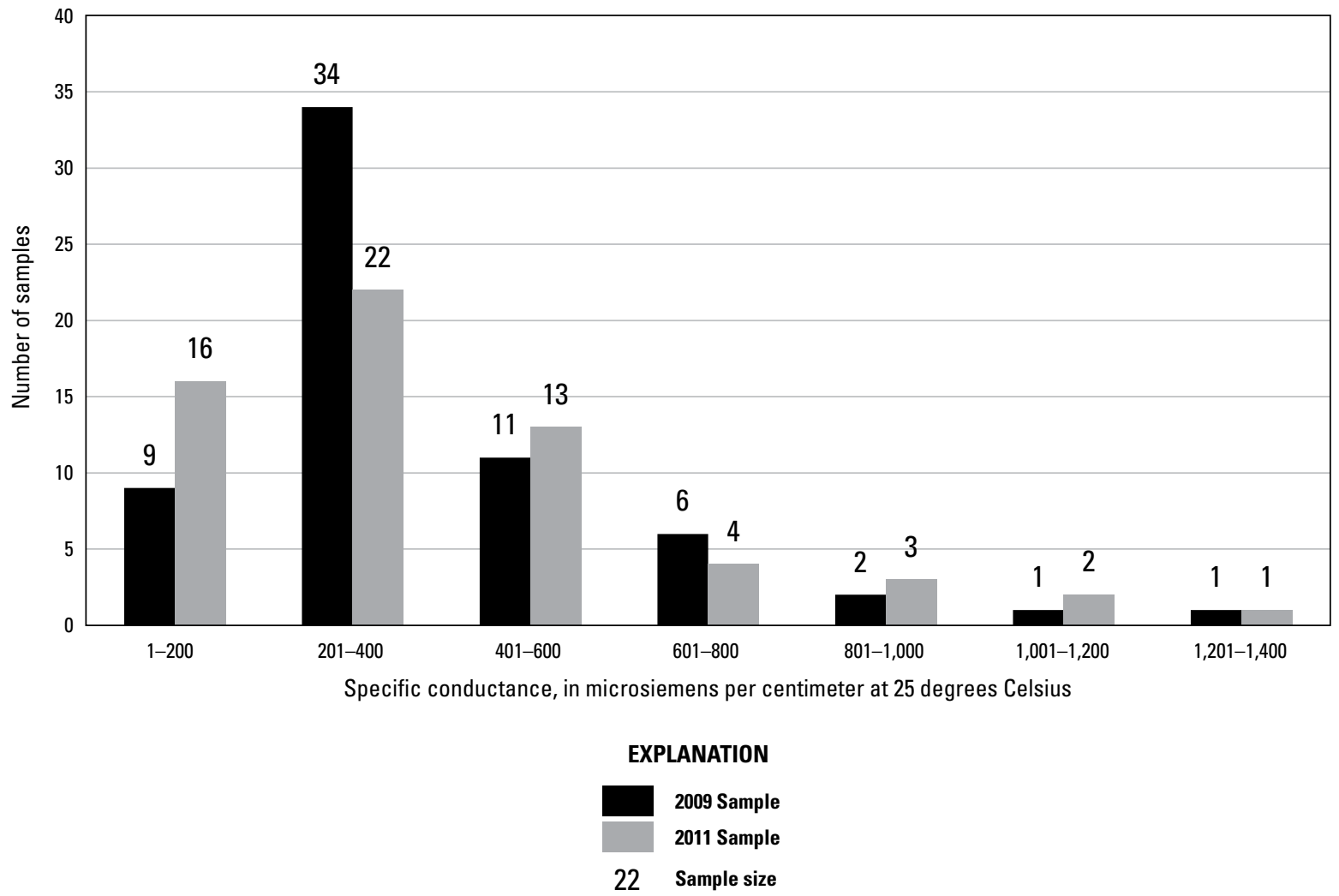

Figure 6. Distribution of specific conductance in samples from the Sparta-Memphis aquifer in 2009 and 2011.

\section{Summary}

The U.S. Geological Survey, in cooperation with the Arkansas Natural Resources Commission and the Arkansas Geological Survey, has monitored water levels since the 1920s. Groundwater withdrawals have increased while water levels have declined since monitoring was initiated. During the spring of 2011, 291 water levels were measured in wells completed in the Sparta-Memphis aquifer. During the summer of 2011, 61 water-quality samples were collected and measured for specific conductance, temperature, and $\mathrm{pH}$ from wells completed in the Sparta-Memphis aquifer.

Water use in the Sparta-Memphis aquifer in Arkansas generally increased from 1965 to 2000. In 2000, water use in the Sparta-Memphis aquifer was about 287 million gallons per day (Mgal/d), an increase of about 156 percent from 1965. In 2005, water use in the Sparta-Memphis aquifer declined to about $170 \mathrm{Mgal} / \mathrm{d}$.

The Sparta Sand is composed of a sequence of alternating sand and clay beds between the massive clays of the overlying Cook Mountain Formation and the underlying Cane River Formation confining units. The Sparta Sand is in the southern part of the study area (south of about 35 degrees latitude). The Memphis Sand is in the northern part of the study area (north of about 35 degrees latitude). The Memphis Sand is underlain by a thick layer of clay in the upper part of the Wilcox Group.
The regional direction of groundwater flow in the SpartaMemphis aquifer is generally to the south-southeast in the northern half of Arkansas and flows east and south in the southern half of Arkansas. The groundwater in the southern half of Arkansas flows away from the outcrop area except where affected by large depressions in the potentiometric surface. The highest water-level altitude measured in the Sparta-Memphis aquifer was 326 feet (ft) above the National Geodetic Vertical Datum of 1929 (NGVD 29) in the outcrop at the western boundary of the study area in Grant County; the lowest water-level altitude was 120 feet (ft) below NGVD 29 in Union County.

Five depressions are located in the following counties: Arkansas, Cleveland, Jefferson, Lincoln, and Prairie; Union; Cross, Poinsett, St. Francis, and Woodruff; Columbia; and Bradley. Two large depressions, centered in Jefferson and Union Counties, are the result of large withdrawals for industrial, irrigation, or public supply. The depression centered in Jefferson County has expanded in recent years into Arkansas and Prairie Counties as a result of large withdrawals for irrigation and public supply. The lowest water-level altitude measured in this depression is approximately $20 \mathrm{ft}$ higher in 2011 than in 2009. The area enclosed within the $40-\mathrm{ft}$ contour on the 2011 potentiometric-surface map has decreased in area, shifting north in Lincoln County and west in Arkansas County when compared with the 2009 potentiometric-surface map. 
The depression in Union County is roughly circular within the -60-ft contour. The lowest water-level altitude measurement was $157 \mathrm{ft}$ below NGVD 29 in 2009, with a $37-\mathrm{ft}$ rise to $120 \mathrm{ft}$ below NGVD 29 in 2011. The depression in Union County has diminished and encloses a smaller area than in recent years. In 1993, the $-60-\mathrm{ft}$ contour enclosed 632 square miles $\left(\mathrm{mi}^{2}\right)$. In 2003, the $-60-\mathrm{ft}$ contour enclosed $767 \mathrm{mi}^{2}$, an increase of 21 percent from 1993. In 2007, the -60-ft contour enclosed $699 \mathrm{mi}^{2}$, an increase of 10 percent from 1993. In 2011, the -60-ft contour enclosed $375 \mathrm{mi}^{2}$, a decrease of 41 percent from 1993. The lowest waterlevel altitude measurement during 2011 in the center of the depression in Union County represents a rise of $79 \mathrm{ft}$ since 2003. The area enclosed by the lowest altitude contour, $120 \mathrm{ft}$ below NGVD 29, on the 2011 potentiometric-surface map is less than 10 percent the area enclosed by that same conour on the 2009 potentiometric-surface map.

A broad depression, first shown in the 1995 potentiometric-surface map, in western Poinsett and Cross Counties has both increased and decreased in size since 1995. In 2011, the lowest water-level altitude measurement in this depression, $129 \mathrm{ft}$ above NGVD 29, is $2 \mathrm{ft}$ lower than in 2009. The 140-ft contour extended southwest into northwestern St. Francis and east-central Woodruff Counties in 2011. In Columbia County in 2011, the area of the depression decreased, with water levels rising about $1 \mathrm{ft}$ since 2005 in the well with the lowest water-level altitude measurement. The depression in Bradley County in 2011 declined in area compared to 2007.

A water-level difference map was constructed using the difference between water-level measurements made during 2007 and 2011 at 247 wells. The differences in water level between 2007 and 2011 ranged from $-17.3 \mathrm{ft}$ to $45.4 \mathrm{ft}$, with a mean of $4.1 \mathrm{ft}$. In central Union County, water levels in seven wells rose $20 \mathrm{ft}$ or more, with an average annual rise of $5 \mathrm{ft}$ or more. Water levels generally declined in the northern half of the study area and generally increased in the southern half of the study area. Areas with a general decline in water levels include Lonoke and western Prairie Counties; northern Arkansas County; Miller County; and Craighead, Poinsett, Cross, and Woodruff Counties. Areas with a general rise in water levels include Lafayette, Columbia, Union, Calhoun, and Bradley Counties; Grant, Jefferson, southern Arkansas, Lincoln, Drew, and Desha Counties; and Phillips County.

Hydrographs from 183 wells with a minimum of 25 years of water-level measurements were constructed. During the period 1987-2011, county mean annual water levels generally declined. Mean annual declines were between $0.5 \mathrm{ft} / \mathrm{yr}$ and $0.0 \mathrm{ft} / \mathrm{yr}$ in Ashley, Chicot, Crittenden, Drew, Grant, Jefferson, Lafayette, Mississippi, Monroe, Ouachita, Phillips, Pulaski, St. Francis, and Woodruff Counties. Mean annual declines were between 1.0 foot per year (ft/yr) and $0.5 \mathrm{ft} / \mathrm{yr}$ in Bradley, Calhoun, Cleveland, Craighead, Cross, Desha, Lonoke, Miller, Poinsett, and Prairie Counties. Mean annual declines were between $1.5 \mathrm{ft} / \mathrm{yr}$ and $1.0 \mathrm{ft} / \mathrm{yr}$ in Arkansas, Lee, and
Lincoln Counties. The county mean annual water level rose in Columbia, Dallas, and Union Counties, about $0.3 \mathrm{ft} / \mathrm{yr}, 0.1 \mathrm{ft} /$ $\mathrm{yr}$, and $1.2 \mathrm{ft} / \mathrm{yr}$, respectively.

Water samples were collected in the summer of 2011 from 61 wells completed in the Sparta-Memphis aquifer and measured onsite for specific conductance, $\mathrm{pH}$, and temperature. Although there is a regional increase in specific conductance to the east and south, anomalous increases occur in some parts of the study area. Specific conductance ranged from 35 microsiemens per centimeter $(\mu \mathrm{S} / \mathrm{cm})$ in Ouachita County to $1,380 \mu \mathrm{S} / \mathrm{cm}$ in Monroe County. Relatively large specific conductance values (greater than $700 \mu \mathrm{S} / \mathrm{cm}$ ) occur in samples from wells in Arkansas, Ashley, Clay, Monroe, Phillips, and Union Counties.

\section{Selected References}

Broom, M.E., Kraemer, T.F., and Bush, W.V., 1984, A reconnaissance study of saltwater contamination in the El Dorado aquifer, Union County, Arkansas: U.S. Geological Survey Water-Resources Investigations Report 84-4012, $47 \mathrm{p}$.

Cunningham, W.L., and Schalk, C.W., comps., 2011, Groundwater technical procedures of the U.S. Geological Survey: U.S. Geological Survey Techniques and Methods book 1, chap. A1, $151 \mathrm{p}$.

Edds, Joe, and Fitzpatrick, D.J., 1985, Maps showing altitude of the potentiometric surface and changes in water levels of the Sparta Sand and Memphis Sand aquifers in eastern Arkansas, spring 1984: U.S. Geological Survey WaterResources Investigations Report 85-4223, 1 sheet.

Edds, Joe, and Fitzpatrick, D.J., 1989, Altitude of the potentiometric surface and changes in water levels in the Sparta-Memphis aquifer in eastern and southern Arkansas, spring 1986: U.S. Geological Survey Water-Resources Investigations Report 88-4042, 1 sheet.

Fenneman, N.M., 1938, Physiography of eastern United States: New York, McGraw-Hill Book Co., Inc., 689 p.

Fenneman, N.M., and Johnson, D.W., 1946, Physical divisions of the United States (Map): Washington, D.C., U.S. Geological Survey, scale 1:7,000,000.

Fishman, M.J., and Friedman, L.C., 1989, Methods for determination of inorganic substances in water and fluvial sediments: U.S. Geological Survey Techniques of WaterResources Investigations, book 5, chap. A1, 545 p.

Halberg, H.N., 1972, Use of water in Arkansas, 1970: Arkansas Geological Commission, Water Resources Summary Number 7, 17 p. 
Halberg, H.N., 1977, Use of water in Arkansas, 1975: Arkansas Geological Commission, Water Resources Summary Number 9, 28 p.

Halberg, H.N., and Stephens, J.W., 1966, Use of water in Arkansas, 1965: Arkansas Geological Commission, Water Resources Summary Number 5, 12 p.

Hart, R.M., Clark, B.R., and Bolyard, S.E., 2008, Digital surfaces and thicknesses of selected hydrogeologic units within the Mississippi Embayment Regional Aquifer Study (MERAS): U.S. Geological Survey Scientific Investigations Report 2008-5098, accessed March 9, 2009, at http://pubs.usgs.gov/sir/2008/5098/.

Helsel, D.R., and Hirsch, R.M., 1992, Statistical methods in water resources: New York, N.Y., Elsevier Science Publishing Co., 522 p.

Hem, J.D., 1985, Study and interpretation of the chemical characteristics of natural water: U.S. Geological Survey Water Supply Paper 2254, 263 p.

Holland, T.W., 1987, Use of water in Arkansas, 1985: Arkansas Geological Commission Water Resources Summary Number 14, 30 p.

Holland, T.W., 1993, Use of water in Arkansas, 1990: U.S Geological Survey Open-File Report 93-48, pamphlet.

Holland, T.W., 1999, Water use in Arkansas, 1995: U.S. Geological Survey Open-File Report 99-188, 1 sheet.

Holland, T.W., 2004, Estimated water use in Arkansas, 2000: U.S. Geological Survey Scientific Investigations Report 2004-5230, 31 p.

Holland, T.W., 2007, Water use in Arkansas, 2005: U.S. Geological Survey Scientific Investigations Report 2007 5241, $31 \mathrm{p}$.

Holland, T.W., and Ludwig, A.H., 1981, Use of water in Arkansas: Arkansas Geological Commission, Water Resources Summary Number 14, 30 p.

Hosman, R.L., 1982, Outcropping Tertiary units in southern Arkansas: U.S. Geological Survey Miscellaneous Investigations Series I-1405, 1 sheet.

Hosman, R.L., Long, A.T., Lambert, T.W., and others, 1968, Tertiary aquifers in the Mississippi Embayment: U.S. Geological Survey Professional Paper 448-D, 29 p.

Hosman, R.L., and Weiss, J.S., 1991, Geohydrologic units of the Mississippi Embayment and Texas Coastal Uplands aquifer systems, South-Central United States: U.S. Geological Survey Professional Paper 1416-B, 19 p.
Joseph, R.L., 1998, Potentiometric surface of the Sparta aquifer in eastern and south-central Arkansas and northcentral Louisiana, and the Memphis aquifer in east-central Arkansas, October 1996-July 1997: U.S. Geological Survey Water-Resources Investigations Report 97-4282, 19 p.

Joseph, R.L., 2000, Status of water levels and selected waterquality conditions in the Sparta and Memphis aquifers in eastern and south-central Arkansas, 1999: U.S. Geological Survey Water-Resources Investigations Report 00-4009, $34 \mathrm{p}$.

Morris, E.E., and Bush, W.V., 1986, Extent and source of saltwater intrusion into the alluvial aquifer near Brinkley, Arkansas, 1984: U.S. Geological Survey Water-Resources Investigations Report 85-4322, 123 p.

Payne, J.N., 1968, Hydrologic significance of the lithofacies of the Sparta Sand in Arkansas, Louisiana, Mississippi, and Texas: U.S. Geological Survey Professional Paper 569-A, $17 \mathrm{p}$.

Petersen, J.C., Broom, M.E., and Bush, W.V., 1985, Geohydrologic units of the Gulf Coastal Plain in Arkansas: U.S. Geological Survey Water-Resources Investigations Report 85-4116, 20 p.

Schrader, T.P., 2004, Status of water levels and selected water-quality conditions in the Sparta-Memphis aquifer in Arkansas and the Sparta aquifer in Louisiana, springsummer 2001: U.S. Geological Survey Scientific Investigations Report 2004-5055, 52 p.

Schrader, T.P., 2006, Status of water levels and selected water-quality conditions in the Sparta-Memphis aquifer in Arkansas, spring-summer, 2003: U.S. Geological Survey Scientific Investigations Report 2006-5021, 43 p.

Schrader, T.P., 2008, Potentiomentric surface in the SpartaMemphis aquifer of the Mississippi Embayment, spring 2007: U.S. Geological Survey Scientific Investigations Map 3014, 1 pl.

Schrader, T.P., 2009, Water levels and selected water-quality conditions in the Sparta-Memphis aquifer (middle Claiborne aquifer) in Arkansas, spring-summer 2007: U.S. Geological Survey Scientific Investigations Report 2009-5207, 50 p.

Schrader, T.P., 2010, Water levels and selected water-quality conditions in the Mississippi River Valley alluvial aquifer in eastern Arkansas, 2008: U.S. Geological Survey Scientific Investigations Report 2010-5140, 71 p.

Schrader, T.P., 2013, Water levels and water-quality in the Sparta-Memphis aquifer (middle Claiborne aquifer) in Arkansas, spring-summer 2009: U.S. Geological Survey Scientific Investigations Report 2013-5100, 53 p. 


\section{Water Levels and Water Quality in the Sparta-Memphis Aquifer (Middle Claiborne Aquifer) in Arkansas}

Schrader, T.P., and Jones, J.S., 2007, Status of water levels and selected water-quality conditions in the SpartaMemphis aquifer in Arkansas and the status of water levels in the Sparta aquifer in Louisiana, spring 2005: U.S. Geological Survey Scientific Investigations Report 2007-5029, $66 \mathrm{p}$.

Scheiderer, R.M., and Freiwald, D.A., 2006, Monitoring the recovery of the Sparta aquifer in southern Arkansas and northern Louisiana: U.S. Geological Survey Fact Sheet 2006-3090, 4 p.

Snider, J.L., Calandro, A.J., and Shampine, W.J., 1972, Water resources of Union Parish, Louisiana: Department of Conservation, Louisiana Geological Survey, and Louisiana Department of Public Works Water Resources Bulletin no. $17,68 \mathrm{p}$.
Stanton, G.P., 1997, Potentiometric surface and specific conductance of the Sparta and Memphis aquifers in eastern and south-central Arkansas, 1995: U.S. Geological Survey Water-Resources Investigations Report 97-4119, $16 \mathrm{p}$.

U.S. Geological Survey, variously dated, National field manual for the collection of water-quality data: U.S. Geological Survey Techniques of Water-Resources Investigations, book 9, chaps. A1-A9. [Also available at http://pubs.water. usgs.gov/twri9A.]

Westerfield, P.A., 1995, Potentiometric surface of the Sparta and Memphis aquifers in eastern Arkansas, April through July 1993: U.S. Geological Survey Water-Resources Investigations Report 95-4000, 1 sheet. 
Appendixes 1-3 

Appendix 1. Water-level data collected during spring 2011 from wells completed in the Sparta-Memphis aquifer in Arkansas.

[NGVD 29, National Geodetic Vertical Datum of 1929; horizontal coordinate information is referenced to the North American Datum of 1983 (NAD 83)]

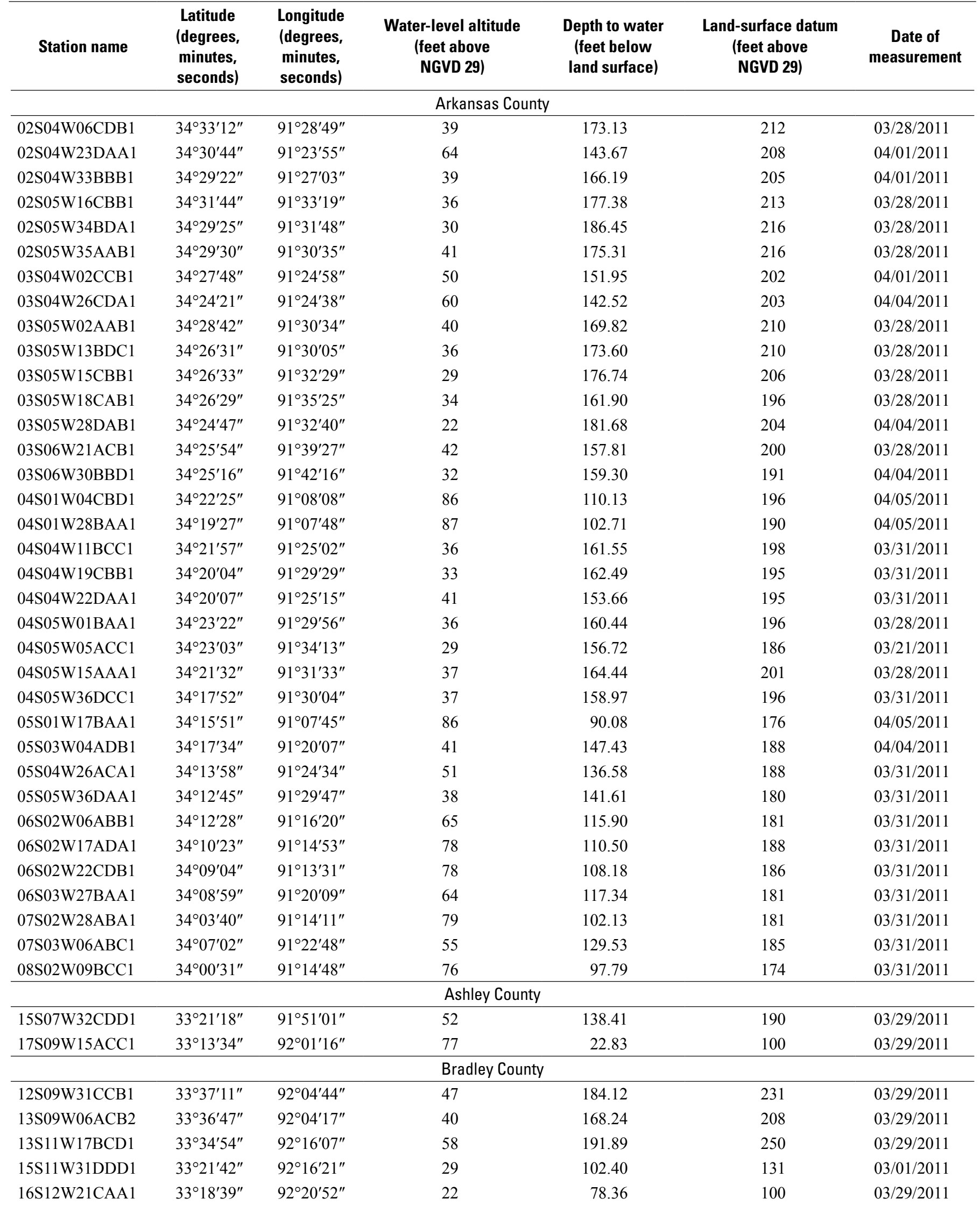


Appendix 1. Water-level data collected during spring 2011 from wells completed in the Sparta-Memphis aquifer in Arkansas.Continued

[NGVD 29, National Geodetic Vertical Datum of 1929; horizontal coordinate information is referenced to the North American Datum of 1983 (NAD 83)]

\begin{tabular}{|c|c|c|c|c|c|c|}
\hline Station name & $\begin{array}{l}\text { Latitude } \\
\text { (degrees, } \\
\text { minutes, } \\
\text { seconds) }\end{array}$ & $\begin{array}{l}\text { Longitude } \\
\text { (degrees, } \\
\text { minutes, } \\
\text { seconds) }\end{array}$ & $\begin{array}{l}\text { Water-level altitude } \\
\text { (feet above } \\
\text { NGVD 29) }\end{array}$ & $\begin{array}{l}\text { Depth to water } \\
\text { (feet below } \\
\text { land surface) }\end{array}$ & $\begin{array}{l}\text { Land-surface datum } \\
\text { (feet above } \\
\text { NGVD 29) }\end{array}$ & $\begin{array}{c}\text { Date of } \\
\text { measurement }\end{array}$ \\
\hline 13S13W32CDA1 & $33^{\circ} 32^{\prime} 27^{\prime \prime}$ & $92^{\circ} 27^{\prime} 42^{\prime \prime}$ & 33 & 175.50 & 208 & $05 / 19 / 2011$ \\
\hline 14S13W03CAB1 & $33^{\circ} 31^{\prime} 45^{\prime \prime}$ & $92^{\circ} 25^{\prime} 51^{\prime \prime}$ & 33 & 169.08 & 202 & 05/19/2011 \\
\hline 14S13W12CCB1 & $33^{\circ} 30^{\prime} 40^{\prime \prime}$ & $92^{\circ} 24^{\prime} 04^{\prime \prime}$ & 40 & 165.18 & 205 & 05/19/2011 \\
\hline \multicolumn{7}{|c|}{ Chicot County } \\
\hline 13S03W22DAD1 & $33^{\circ} 33^{\prime} 12^{\prime \prime}$ & $91^{\circ} 23^{\prime} 08^{\prime \prime}$ & 64 & 70.74 & 135 & $03 / 29 / 2011$ \\
\hline 15S03W07BCC1 & $33^{\circ} 24^{\prime} 45^{\prime \prime}$ & $91^{\circ} 27^{\prime} 23^{\prime \prime}$ & 64 & 65.35 & 129 & 03/29/2011 \\
\hline \multicolumn{7}{|c|}{ Cleveland County } \\
\hline 10S09W35ACD1 & $33^{\circ} 47^{\prime} 58^{\prime \prime}$ & $91^{\circ} 59^{\prime} 57^{\prime \prime}$ & 54 & 164.96 & 219 & 05/18/2011 \\
\hline 10S12W12BDD1 & $33^{\circ} 51^{\prime} 33^{\prime \prime}$ & $92^{\circ} 17^{\prime} 43^{\prime \prime}$ & 101 & 118.83 & 220 & 05/18/2011 \\
\hline 11S11W16AAB1 & $33^{\circ} 45^{\prime} 43^{\prime \prime}$ & $92^{\circ} 14^{\prime} 23^{\prime \prime}$ & 100 & 202.97 & 303 & 05/18/2011 \\
\hline \multicolumn{7}{|c|}{ Columbia County } \\
\hline 15S20W20CCB1 & $33^{\circ} 24^{\prime} 53^{\prime \prime}$ & $93^{\circ} 12^{\prime} 15^{\prime \prime}$ & 156 & 216.45 & 372 & $03 / 24 / 2011$ \\
\hline 16S20W08DCC1 & $33^{\circ} 21^{\prime} 14^{\prime \prime}$ & $93^{\circ} 11^{\prime} 41^{\prime \prime}$ & 87 & 315.03 & 402 & 03/25/2011 \\
\hline 16S21W14CBB1 & $33^{\circ} 20^{\prime} 49^{\prime \prime}$ & $93^{\circ} 15^{\prime} 17^{\prime \prime}$ & 77 & 203.83 & 281 & $03 / 21 / 2011$ \\
\hline 16S21W20DAD1 & $33^{\circ} 19^{\prime} 55^{\prime \prime}$ & $93^{\circ} 17^{\prime} 36^{\prime \prime}$ & 96 & 254.43 & 350 & $03 / 21 / 2011$ \\
\hline 16S22W22CCD1 & $33^{\circ} 19^{\prime} 48^{\prime \prime}$ & $93^{\circ} 22^{\prime} 25^{\prime \prime}$ & 207 & 132.97 & 340 & $03 / 14 / 2011$ \\
\hline 17S19W15AAB1 & $33^{\circ} 15^{\prime} 46^{\prime \prime}$ & $93^{\circ} 03^{\prime} 18^{\prime \prime}$ & 41 & 277.31 & 318 & $03 / 22 / 2011$ \\
\hline 17S20W36ABC1 & $33^{\circ} 13^{\prime} 07^{\prime \prime}$ & $93^{\circ} 07^{\prime} 55^{\prime \prime}$ & 42 & 293.06 & 335 & $03 / 23 / 2011$ \\
\hline 17S21W01BBC1 & $33^{\circ} 17^{\prime} 43^{\prime \prime}$ & $93^{\circ} 14^{\prime} 24^{\prime \prime}$ & 55 & 250.37 & 305 & $03 / 21 / 2011$ \\
\hline 17S21W08DCA1 & $33^{\circ} 16^{\prime} 13^{\prime \prime}$ & $93^{\circ} 17^{\prime} 58^{\prime \prime}$ & 91 & 208.90 & 300 & $03 / 22 / 2011$ \\
\hline 17S21W11DCC2 & $33^{\circ} 16^{\prime} 09^{\prime \prime}$ & $93^{\circ} 14^{\prime} 49^{\prime \prime}$ & 28 & 271.97 & 300 & $03 / 22 / 2011$ \\
\hline 17S21W11DCC3 & $33^{\circ} 16^{\prime} 09^{\prime \prime}$ & $93^{\circ} 14^{\prime} 49^{\prime \prime}$ & 22 & 275.71 & 298 & $03 / 22 / 2011$ \\
\hline 17S21W17BAB1 & $33^{\circ} 16^{\prime} 08^{\prime \prime}$ & $93^{\circ} 18^{\prime} 20^{\prime \prime}$ & 88 & 198.95 & 287 & $03 / 22 / 2011$ \\
\hline 17S22W21ABD1 & $33^{\circ} 15^{\prime} 17^{\prime \prime}$ & $93^{\circ} 23^{\prime} 04^{\prime \prime}$ & 214 & 81.45 & 295 & $03 / 22 / 2011$ \\
\hline 17S22W22ABB1 & $33^{\circ} 15^{\prime} 22^{\prime \prime}$ & $93^{\circ} 22^{\prime} 10^{\prime \prime}$ & 185 & 135.75 & 321 & $03 / 23 / 2011$ \\
\hline 17S22W23BBB1 & $33^{\circ} 15^{\prime} 21^{\prime \prime}$ & $93^{\circ} 21^{\prime} 37^{\prime \prime}$ & 191 & 148.78 & 340 & $03 / 22 / 2011$ \\
\hline 18S20W06DDC1 & $33^{\circ} 11^{\prime} 43^{\prime \prime}$ & $93^{\circ} 12^{\prime} 49^{\prime \prime}$ & 1 & 299.43 & 300 & 03/22/2011 \\
\hline 18S20W08CBC1 & $33^{\circ} 11^{\prime} 15^{\prime \prime}$ & $93^{\circ} 12^{\prime} 27^{\prime \prime}$ & -9 & 272.02 & 263 & $03 / 23 / 2011$ \\
\hline 18S20W10CAA1 & $33^{\circ} 10^{\prime} 54^{\prime \prime}$ & $93^{\circ} 10^{\prime} 16^{\prime \prime}$ & 19 & 271.29 & 290 & $03 / 23 / 2011$ \\
\hline 19S20W08DAB1 & $33^{\circ} 05^{\prime} 58^{\prime \prime}$ & $93^{\circ} 11^{\prime} 56^{\prime \prime}$ & 53 & 274.62 & 328 & 03/02/2011 \\
\hline 19S20W09CBD1 & $33^{\circ} 05^{\prime} 55^{\prime \prime}$ & $93^{\circ} 11^{\prime} 29^{\prime \prime}$ & 69 & 262.52 & 332 & 03/23/2011 \\
\hline 19S20W34BDD1 & $33^{\circ} 02^{\prime} 39^{\prime \prime}$ & $93^{\circ} 10^{\prime} 31^{\prime \prime}$ & 83 & 206.98 & 290 & 03/23/2011 \\
\hline
\end{tabular}


Appendix 1. Water-level data collected during spring 2011 from wells completed in the Sparta-Memphis aquifer in Arkansas.Continued

[NGVD 29, National Geodetic Vertical Datum of 1929; horizontal coordinate information is referenced to the North American Datum of 1983 (NAD 83)]

\begin{tabular}{|c|c|c|c|c|c|c|}
\hline Station name & $\begin{array}{l}\text { Latitude } \\
\text { (degrees, } \\
\text { minutes, } \\
\text { seconds) }\end{array}$ & $\begin{array}{l}\text { Longitude } \\
\text { (degrees, } \\
\text { minutes, } \\
\text { seconds) }\end{array}$ & $\begin{array}{c}\text { Water-level altitude } \\
\text { (feet above } \\
\text { NGVD 29) }\end{array}$ & $\begin{array}{l}\text { Depth to water } \\
\text { (feet below } \\
\text { land surface) }\end{array}$ & $\begin{array}{l}\text { Land-surface datum } \\
\text { (feet above } \\
\text { NGVD 29) }\end{array}$ & $\begin{array}{c}\text { Date of } \\
\text { measurement }\end{array}$ \\
\hline 19S21W16DBB1 & $33^{\circ} 05^{\prime} 17^{\prime \prime}$ & $93^{\circ} 17^{\prime} 24^{\prime \prime}$ & 111 & 172.62 & 284 & $03 / 23 / 2011$ \\
\hline 19S23W10ABD1 & $33^{\circ} 06^{\prime} 44^{\prime \prime}$ & $93^{\circ} 28^{\prime} 33^{\prime \prime}$ & 199 & 43.41 & 242 & $03 / 24 / 2011$ \\
\hline 19S23W14BAB2 & $33^{\circ} 05^{\prime} 55^{\prime \prime}$ & $93^{\circ} 27^{\prime} 52^{\prime \prime}$ & 199 & 44.52 & 244 & $03 / 24 / 2011$ \\
\hline 20S22W11ACD1 & $33^{\circ} 01^{\prime} 09^{\prime \prime}$ & $93^{\circ} 21^{\prime} 33^{\prime \prime}$ & 164 & 106.95 & 271 & $03 / 23 / 2011$ \\
\hline \multicolumn{7}{|c|}{ Craighead County } \\
\hline 13N03E23CDD1 & $35^{\circ} 44^{\prime} 04^{\prime \prime}$ & $90^{\circ} 44^{\prime} 33^{\prime \prime}$ & 155 & 93.16 & 248 & $04 / 28 / 2011$ \\
\hline 15N05E29DBB1 & $35^{\circ} 53^{\prime} 60^{\prime \prime}$ & $90^{\circ} 34^{\prime} 33^{\prime \prime}$ & 232 & 25.95 & 258 & $04 / 28 / 2011$ \\
\hline 15N06E18ACA1 & $35^{\circ} 55^{\prime} 44^{\prime \prime}$ & $90^{\circ} 28^{\prime} 58^{\prime \prime}$ & 211 & 19.21 & 230 & $04 / 27 / 2011$ \\
\hline \multicolumn{7}{|c|}{ Crittenden County } \\
\hline 06N07E01DAD2 & $35^{\circ} 09^{\prime} 58^{\prime \prime}$ & $90^{\circ} 17^{\prime} 38^{\prime \prime}$ & 185 & 23.85 & 209 & $04 / 27 / 2011$ \\
\hline 06N09E08DCC1 & $35^{\circ} 08^{\prime} 50^{\prime \prime}$ & $90^{\circ} 09^{\prime} 22^{\prime \prime}$ & 211 & 3.58 & 215 & $04 / 27 / 2011$ \\
\hline 06N09E23AAB1 & $35^{\circ} 07^{\prime} 45^{\prime \prime}$ & $90^{\circ} 05^{\prime} 53^{\prime \prime}$ & 175 & 46.56 & 222 & $04 / 27 / 2011$ \\
\hline 09N07E21BBB1 & $35^{\circ} 23^{\prime} 41^{\prime \prime}$ & $90^{\circ} 21^{\prime} 31^{\prime \prime}$ & 191 & 25.12 & 216 & $04 / 27 / 2011$ \\
\hline \multicolumn{7}{|c|}{ Cross County } \\
\hline 06N04E06ACA1 & $35^{\circ} 10^{\prime} 04^{\prime \prime}$ & $90^{\circ} 42^{\prime} 38^{\prime \prime}$ & 155 & 202.83 & 358 & $05 / 31 / 2011$ \\
\hline 07N05E04ADD1 & $35^{\circ} 15^{\prime} 38^{\prime \prime}$ & $90^{\circ} 33^{\prime} 30^{\prime \prime}$ & 176 & 33.43 & 209 & $05 / 31 / 2011$ \\
\hline 07S14W31AAA1 & $34^{\circ} 04^{\prime} 25^{\prime \prime}$ & $92^{\circ} 33^{\prime} 34^{\prime \prime}$ & 217 & 113.48 & 330 & $05 / 17 / 2011$ \\
\hline 07S16W20CAB1 & $34^{\circ} 05^{\prime} 55^{\prime \prime}$ & $92^{\circ} 45^{\prime} 45^{\prime \prime}$ & 296 & 25.72 & 322 & $05 / 17 / 2011$ \\
\hline 08S15W34BDC1 & $33^{\circ} 58^{\prime} 59^{\prime \prime}$ & $92^{\circ} 37^{\prime} 30^{\prime \prime}$ & 212 & 28.07 & 240 & 05/17/2011 \\
\hline 08S16W18ACC1 & $34^{\circ} 01^{\prime} 52^{\prime \prime}$ & $92^{\circ} 46^{\prime} 39^{\prime \prime}$ & 233 & 19.22 & 252 & $05 / 17 / 2011$ \\
\hline 09S13W35CCD1 & $33^{\circ} 53^{\prime} 09^{\prime \prime}$ & $92^{\circ} 24^{\prime} 13^{\prime \prime}$ & 127 & 72.75 & 200 & 05/17/2011 \\
\hline 09S14W01BDC1 & $33^{\circ} 57^{\prime} 54^{\prime \prime}$ & $92^{\circ} 29^{\prime} 19^{\prime \prime}$ & 224 & 41.05 & 265 & $05 / 17 / 2011$ \\
\hline 09S16W19CAA1 & $33^{\circ} 56^{\prime} 05^{\prime \prime}$ & $92^{\circ} 47^{\prime} 01^{\prime \prime}$ & 253 & 7.40 & 260 & $05 / 17 / 2011$ \\
\hline 10S13W34ACA2 & $33^{\circ} 48^{\prime} 29^{\prime \prime}$ & $92^{\circ} 24^{\prime} 58^{\prime \prime}$ & 120 & 151.86 & 272 & 05/17/2011 \\
\hline 10S14W27CDB1 & $33^{\circ} 49^{\prime} 08^{\prime \prime}$ & $92^{\circ} 31^{\prime} 38^{\prime \prime}$ & 239 & 30.99 & 270 & $05 / 17 / 2011$ \\
\hline 10S15W11DBB1 & $33^{\circ} 52^{\prime} 01^{\prime \prime}$ & $92^{\circ} 36^{\prime} 32^{\prime \prime}$ & 238 & 57.21 & 295 & 03/03/2011 \\
\hline 10S15W18BCC1 & $33^{\circ} 51^{\prime} 20^{\prime \prime}$ & $92^{\circ} 41^{\prime} 20^{\prime \prime}$ & 252 & 76.18 & 328 & $05 / 17 / 2011$ \\
\hline \multicolumn{7}{|c|}{ Desha County } \\
\hline 09S02W26AAC1 & $33^{\circ} 53^{\prime} 46^{\prime \prime}$ & $91^{\circ} 15^{\prime} 21^{\prime \prime}$ & 86 & 67.50 & 153 & $05 / 26 / 2011$ \\
\hline 09S04W28DDD1 & $33^{\circ} 53^{\prime} 10^{\prime \prime}$ & $91^{\circ} 30^{\prime} 07^{\prime \prime}$ & 48 & 116.54 & 165 & $05 / 26 / 2011$ \\
\hline $10 \mathrm{~S} 02 \mathrm{~W} 26 \mathrm{CCC} 2$ & $33^{\circ} 47^{\prime} 50^{\prime \prime}$ & $91^{\circ} 16^{\prime} 24^{\prime \prime}$ & 78 & 70.07 & 148 & $05 / 26 / 2011$ \\
\hline
\end{tabular}


Appendix 1. Water-level data collected during spring 2011 from wells completed in the Sparta-Memphis aquifer in Arkansas.Continued

[NGVD 29, National Geodetic Vertical Datum of 1929; horizontal coordinate information is referenced to the North American Datum of 1983 (NAD 83)]

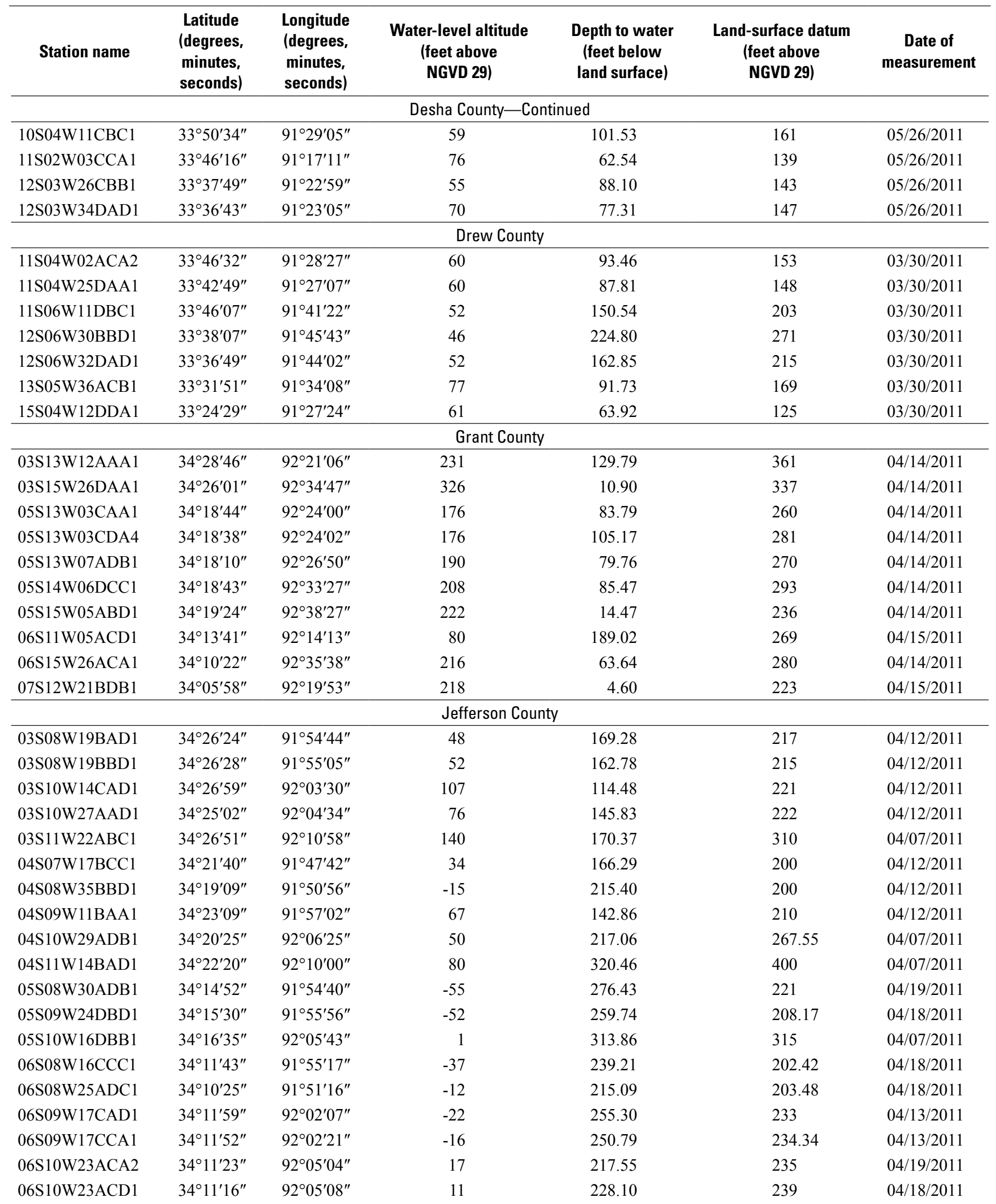


Appendix 1. Water-level data collected during spring 2011 from wells completed in the Sparta-Memphis aquifer in Arkansas.Continued

[NGVD 29, National Geodetic Vertical Datum of 1929; horizontal coordinate information is referenced to the North American Datum of 1983 (NAD 83)]

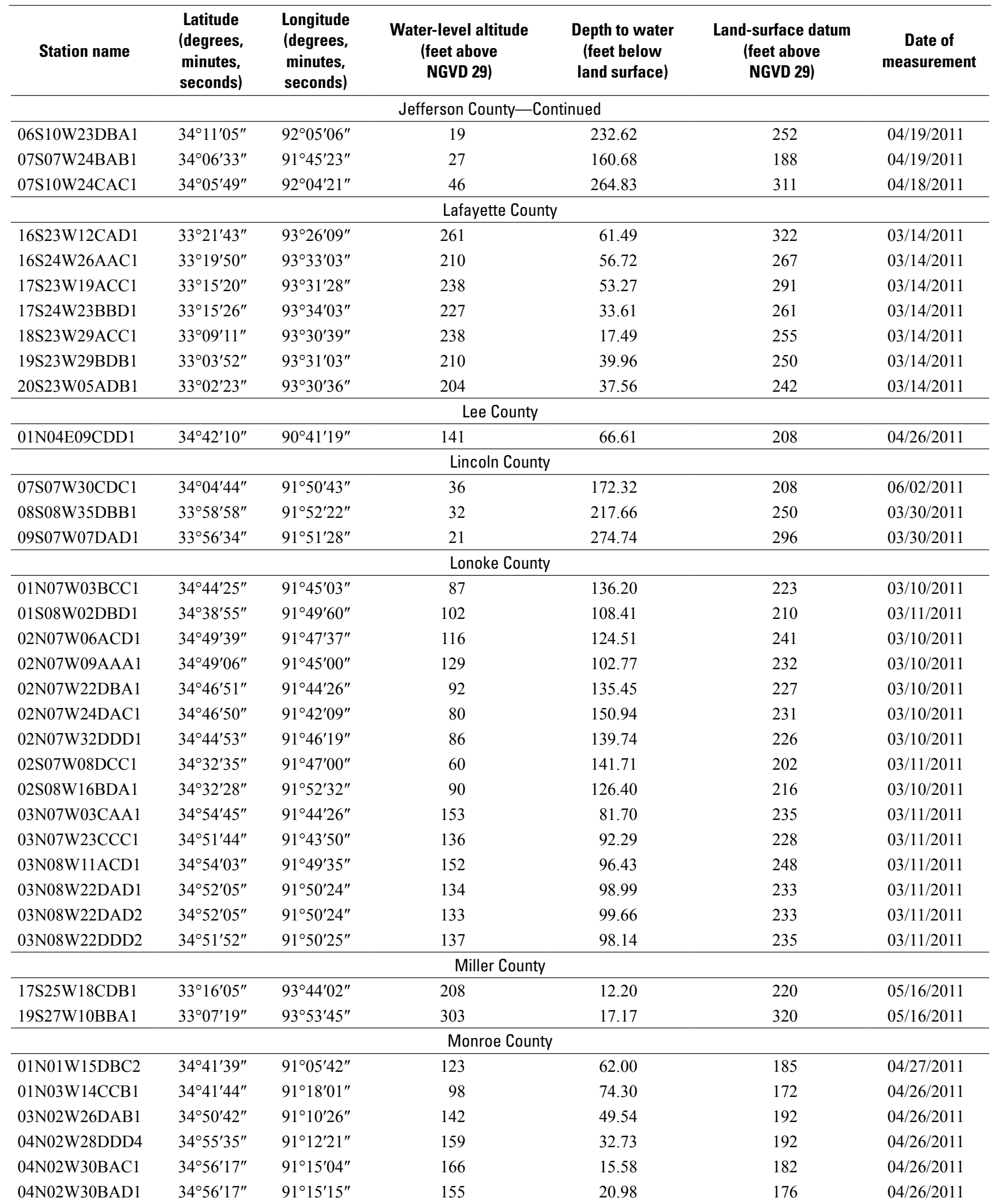


Appendix 1. Water-level data collected during spring 2011 from wells completed in the Sparta-Memphis aquifer in Arkansas.Continued

[NGVD 29, National Geodetic Vertical Datum of 1929; horizontal coordinate information is referenced to the North American Datum of 1983 (NAD 83)]

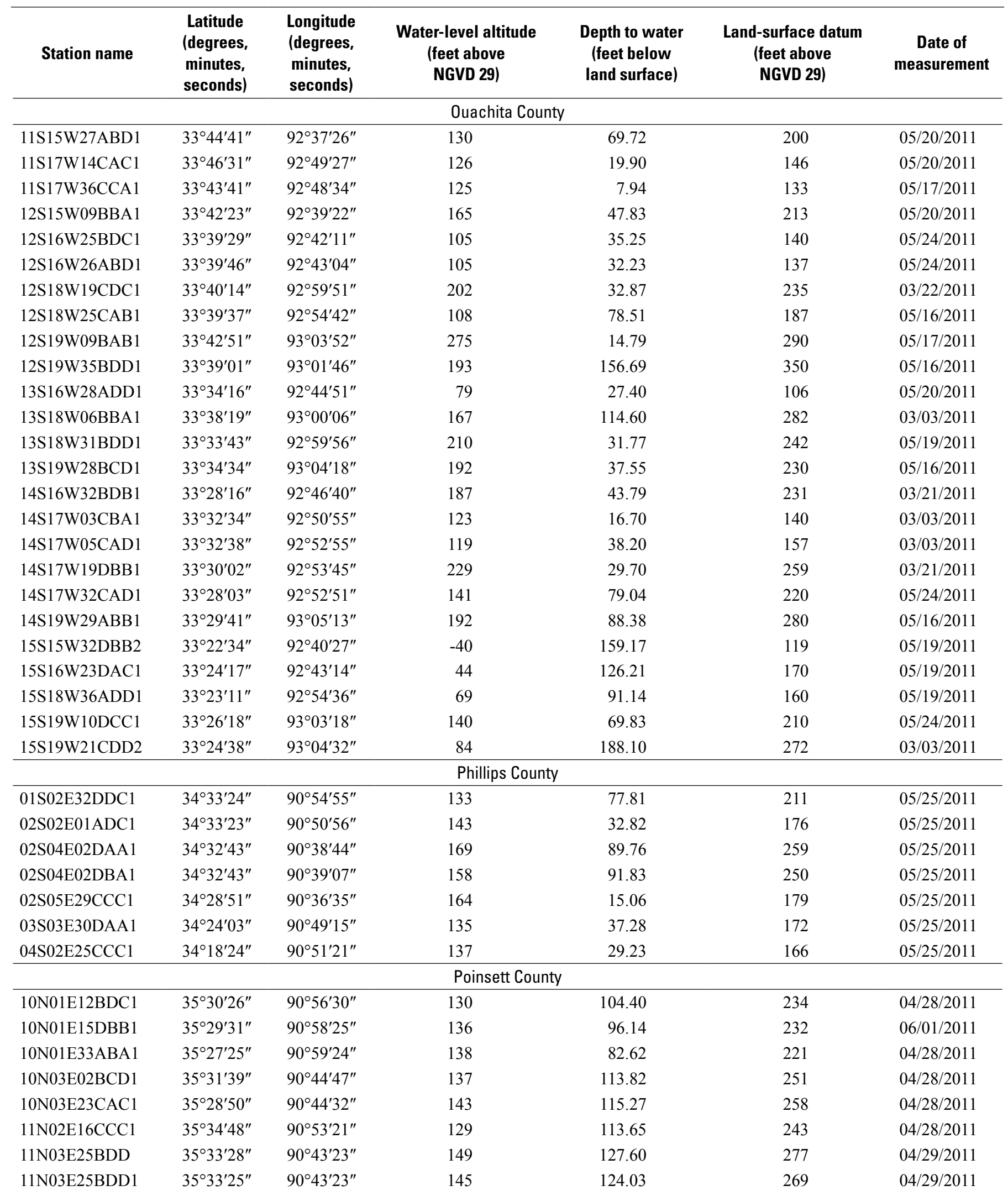


Appendix 1. Water-level data collected during spring 2011 from wells completed in the Sparta-Memphis aquifer in Arkansas.Continued

[NGVD 29, National Geodetic Vertical Datum of 1929; horizontal coordinate information is referenced to the North American Datum of 1983 (NAD 83)]

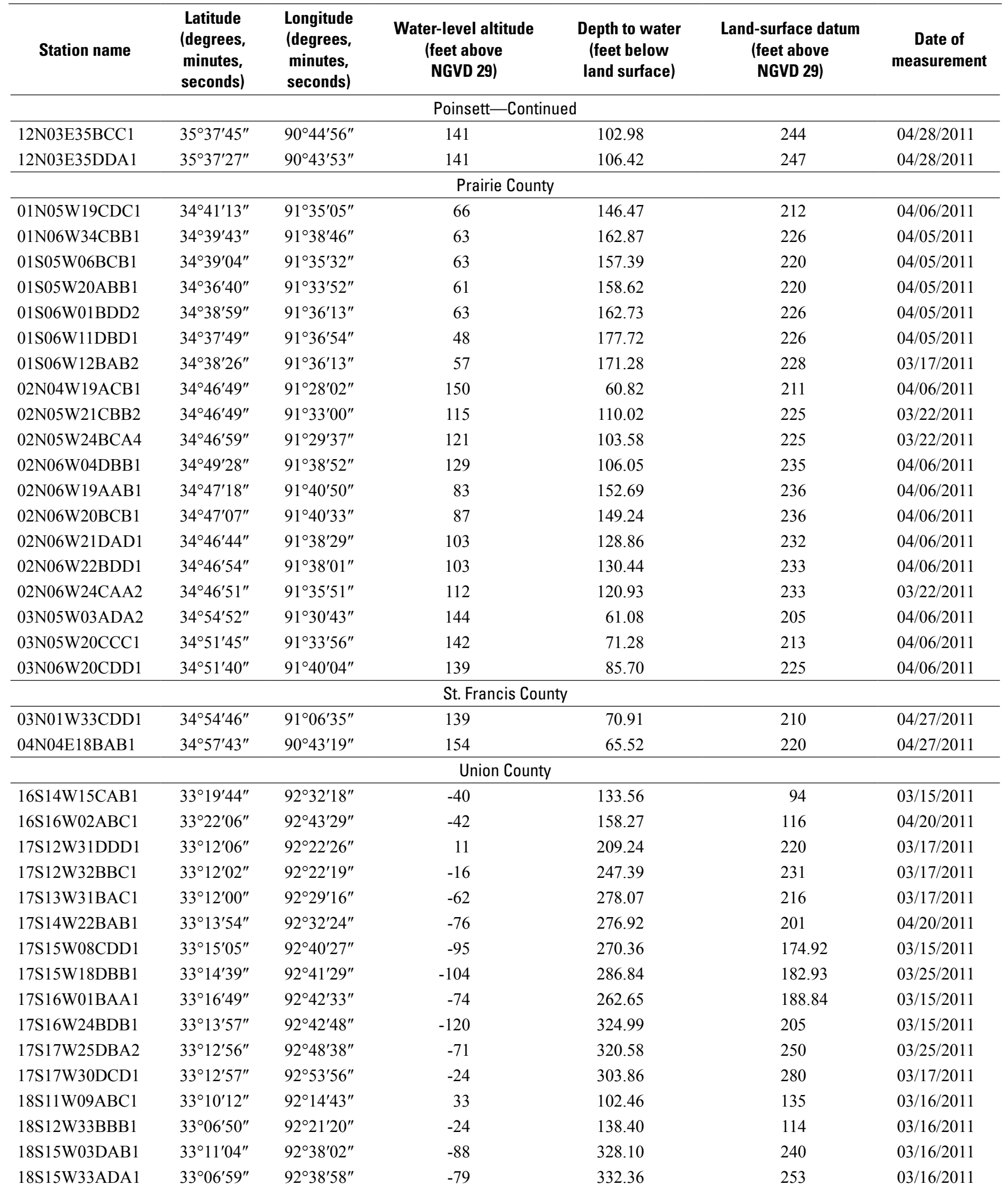




\section{Water Levels and Water Quality in the Sparta-Memphis Aquifer (Middle Claiborne Aquifer) in Arkansas}

Appendix 1. Water-level data collected during spring 2011 from wells completed in the Sparta-Memphis aquifer in Arkansas.Continued

[NGVD 29, National Geodetic Vertical Datum of 1929; horizontal coordinate information is referenced to the North American Datum of 1983 (NAD 83)]

\begin{tabular}{|c|c|c|c|c|c|c|}
\hline Station name & $\begin{array}{l}\text { Latitude } \\
\text { (degrees, } \\
\text { minutes, } \\
\text { seconds) }\end{array}$ & $\begin{array}{c}\text { Longitude } \\
\text { (degrees, } \\
\text { minutes, } \\
\text { seconds) }\end{array}$ & $\begin{array}{l}\text { Water-level altitude } \\
\text { (feet above } \\
\text { NGVD 29) }\end{array}$ & $\begin{array}{l}\text { Depth to water } \\
\text { (feet below } \\
\text { land surface) }\end{array}$ & $\begin{array}{l}\text { Land-surface datum } \\
\text { (feet above } \\
\text { NGVD 29) }\end{array}$ & $\begin{array}{c}\text { Date of } \\
\text { measurement }\end{array}$ \\
\hline \multicolumn{7}{|c|}{ Union County-Continued } \\
\hline 18S15W35DAC1 & $33^{\circ} 06^{\prime} 36^{\prime \prime}$ & $92^{\circ} 37^{\prime} 07^{\prime \prime}$ & -61 & 261.91 & 201 & $03 / 16 / 2011$ \\
\hline 18S16W10CDD1 & $33^{\circ} 10^{\prime} 00^{\prime \prime}$ & $92^{\circ} 44^{\prime} 45^{\prime \prime}$ & -91 & 272.75 & 182 & $03 / 15 / 2011$ \\
\hline 19S10W16CBC1 & $33^{\circ} 03^{\prime} 29^{\prime \prime}$ & $92^{\circ} 09^{\prime} 04^{\prime \prime}$ & -5 & 86.55 & 82 & $03 / 16 / 2011$ \\
\hline 19S11W23ACA1 & $33^{\circ} 02^{\prime} 55^{\prime \prime}$ & $92^{\circ} 12^{\prime} 29^{\prime \prime}$ & -9 & 151.17 & 142 & $03 / 17 / 2011$ \\
\hline 19S11W25AAA1 & $33^{\circ} 02^{\prime} 18^{\prime \prime}$ & $92^{\circ} 11^{\prime} 13^{\prime \prime}$ & -10 & 145.49 & 135 & $03 / 16 / 2011$ \\
\hline 19S12W13AAA1 & $33^{\circ} 04^{\prime} 11^{\prime \prime}$ & $92^{\circ} 17^{\prime} 17^{\prime \prime}$ & 31 & 159.66 & 191 & $03 / 16 / 2011$ \\
\hline 05N01W17DBB1 & $35^{\circ} 03^{\prime} 11^{\prime \prime}$ & $91^{\circ} 07^{\prime} 27^{\prime \prime}$ & 163 & 46.74 & 210 & $05 / 27 / 2011$ \\
\hline 05N02W31DCB3 & $35^{\circ} 00^{\prime} 27^{\prime \prime}$ & $91^{\circ} 14^{\prime} 56^{\prime \prime}$ & 180 & 13.09 & 193 & $05 / 27 / 2011$ \\
\hline 06N01W13ABA1 & $35^{\circ} 08^{\prime} 52^{\prime \prime}$ & $91^{\circ} 02^{\prime} 54^{\prime \prime}$ & 138 & 73.51 & 212 & $05 / 27 / 2011$ \\
\hline 06N01 W13ADC1 & $35^{\circ} 08^{\prime} 27^{\prime \prime}$ & $91^{\circ} 02^{\prime} 47^{\prime \prime}$ & 142 & 70.11 & 212 & $05 / 27 / 2011$ \\
\hline 07N01W12BCB1 & $35^{\circ} 14^{\prime} 42^{\prime \prime}$ & $91^{\circ} 03^{\prime} 26^{\prime \prime}$ & 154 & 68.43 & 222 & $05 / 27 / 2011$ \\
\hline 08N01W12CDA1 & $35^{\circ} 19^{\prime} 34^{\prime \prime}$ & $91^{\circ} 03^{\prime} 11^{\prime \prime}$ & 147 & 77.89 & 225 & $05 / 27 / 2011$ \\
\hline 08N02W26ADC1 & $35^{\circ} 17^{\prime} 26^{\prime \prime}$ & $91^{\circ} 10^{\prime} 04^{\prime \prime}$ & 185 & 27.06 & 212 & $05 / 27 / 2011$ \\
\hline
\end{tabular}


Appendix 2. Difference in water level from 2007 to 2011 in the Sparta-Memphis aquifer in Arkansas.

[Horizontal datum is the North American Datum of 1983; negative values denote a decline; 2007 depth-to-water level from Schrader (2009)]

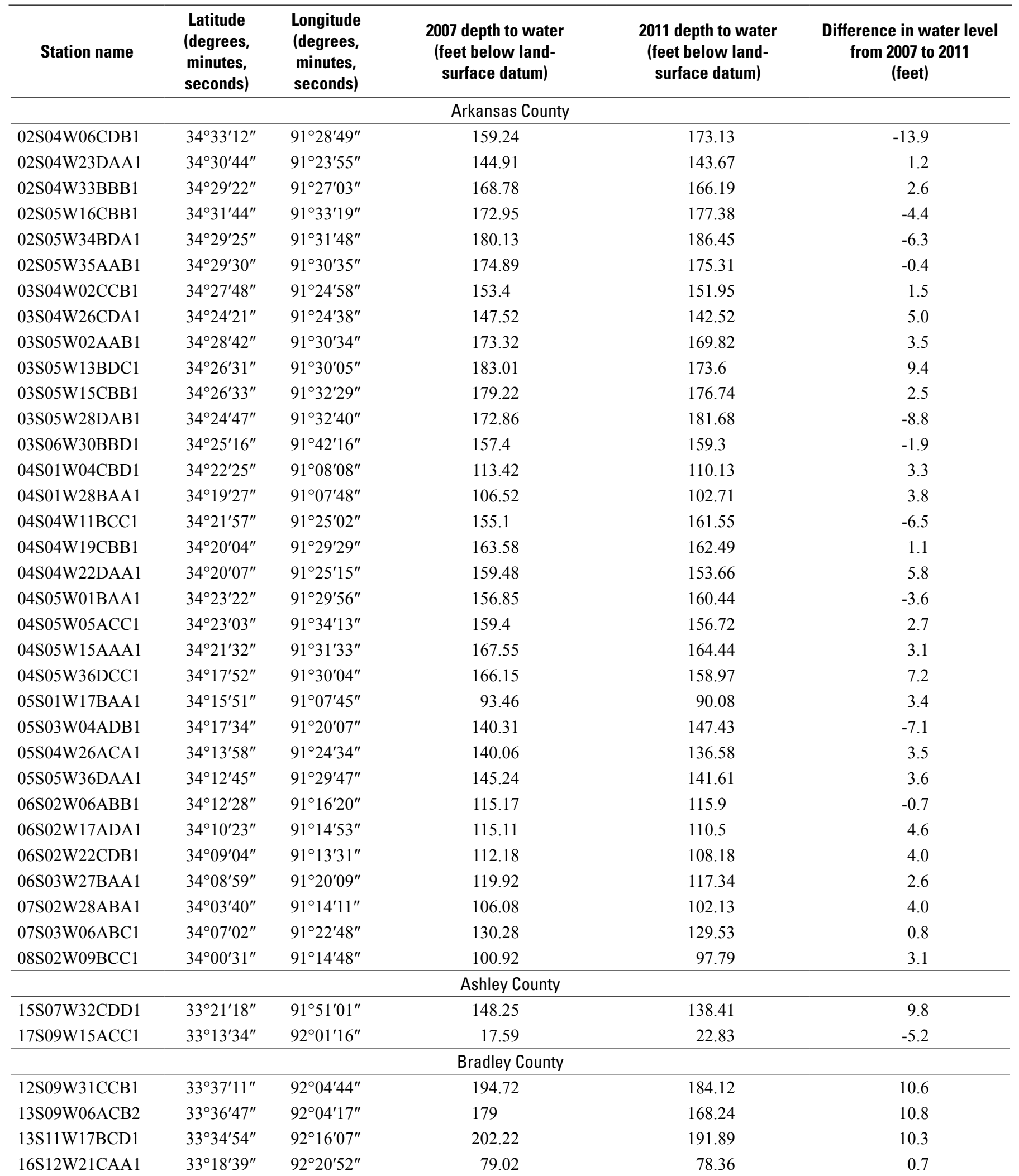


Appendix 2. Difference in water level from 2007 to 2011 in the Sparta-Memphis aquifer in Arkansas.—Continued

[Horizontal datum is the North American Datum of 1983; negative values denote a decline; 2007 depth-to-water level from Schrader (2009)]

\begin{tabular}{|c|c|c|c|c|c|}
\hline Station name & $\begin{array}{l}\text { Latitude } \\
\text { (degrees, } \\
\text { minutes, } \\
\text { seconds) }\end{array}$ & $\begin{array}{l}\text { Longitude } \\
\text { (degrees, } \\
\text { minutes, } \\
\text { seconds) }\end{array}$ & $\begin{array}{l}2007 \text { depth to water } \\
\text { (feet below land- } \\
\text { surface datum) }\end{array}$ & $\begin{array}{l}2011 \text { depth to water } \\
\text { (feet below land- } \\
\text { surface datum) }\end{array}$ & $\begin{array}{c}\text { Difference in water level } \\
\text { from } 2007 \text { to } 2011 \\
\text { (feet) }\end{array}$ \\
\hline 13S13W32CDA1 & $33^{\circ} 32^{\prime} 27^{\prime \prime}$ & $92^{\circ} 27^{\prime} 42^{\prime \prime}$ & 194.83 & 175.5 & 19.3 \\
\hline 14S13W03CAB1 & $33^{\circ} 31^{\prime} 45^{\prime \prime}$ & $92^{\circ} 25^{\prime} 51^{\prime \prime}$ & 167.59 & 169.08 & -1.5 \\
\hline 14S13W12CCB1 & $33^{\circ} 30^{\prime} 40^{\prime \prime}$ & $92^{\circ} 24^{\prime} 04^{\prime \prime}$ & 171.6 & 165.18 & 6.4 \\
\hline \multicolumn{6}{|c|}{ Chicot County } \\
\hline 13S03W22DAD1 & $33^{\circ} 33^{\prime} 12^{\prime \prime}$ & $91^{\circ} 23^{\prime} 08^{\prime \prime}$ & 70.1 & 70.74 & -0.6 \\
\hline 15S03W07BCC1 & $33^{\circ} 24^{\prime} 45^{\prime \prime}$ & $91^{\circ} 27^{\prime} 23^{\prime \prime}$ & 65.11 & 65.35 & -0.2 \\
\hline \multicolumn{6}{|c|}{ Cleveland County } \\
\hline 10S09W35ACD1 & $33^{\circ} 47^{\prime} 58^{\prime \prime}$ & $91^{\circ} 59^{\prime} 57^{\prime \prime}$ & 156.42 & 164.96 & -8.5 \\
\hline 10S12W12BDD1 & $33^{\circ} 51^{\prime} 33^{\prime \prime}$ & $92^{\circ} 17^{\prime} 43^{\prime \prime}$ & 120.26 & 118.83 & 1.4 \\
\hline 11S11W16AAB1 & $33^{\circ} 45^{\prime} 43^{\prime \prime}$ & $92^{\circ} 14^{\prime} 23^{\prime \prime}$ & 204.31 & 202.97 & 1.3 \\
\hline \multicolumn{6}{|c|}{ Columbia County } \\
\hline 16S20W08DCC1 & $33^{\circ} 21^{\prime} 14^{\prime \prime}$ & $93^{\circ} 11^{\prime} 41^{\prime \prime}$ & 319.33 & 315.03 & 4.3 \\
\hline 17S19W15AAB1 & $33^{\circ} 15^{\prime} 46^{\prime \prime}$ & $93^{\circ} 03^{\prime} 18^{\prime \prime}$ & 275.73 & 277.31 & -1.6 \\
\hline 17S19W19BCA1 & $33^{\circ} 14^{\prime} 33^{\prime \prime}$ & $93^{\circ} 07^{\prime} 05^{\prime \prime}$ & 268.97 & 271.36 & -2.4 \\
\hline 17S20W17CDA1 & $33^{\circ} 15^{\prime} 20^{\prime \prime}$ & $93^{\circ} 12^{\prime} 01^{\prime \prime}$ & 313.96 & 305.21 & 8.8 \\
\hline 17S20W36ABC1 & $33^{\circ} 13^{\prime} 07^{\prime \prime}$ & $93^{\circ} 07^{\prime} 55^{\prime \prime}$ & 292.66 & 293.06 & -0.4 \\
\hline 17S21W11DCC2 & $33^{\circ} 16^{\prime} 09^{\prime \prime}$ & $93^{\circ} 14^{\prime} 49^{\prime \prime}$ & 276.11 & 271.97 & 4.1 \\
\hline 19S23W14BAB2 & $33^{\circ} 05^{\prime} 55^{\prime \prime}$ & $93^{\circ} 27^{\prime} 52^{\prime \prime}$ & 52.58 & 44.52 & 8.1 \\
\hline 20S22W11ACD1 & $33^{\circ} 01^{\prime} 09^{\prime \prime}$ & $93^{\circ} 21^{\prime} 33^{\prime \prime}$ & 108.04 & 106.95 & 1.1 \\
\hline \multicolumn{6}{|c|}{ Craighead County } \\
\hline 13N03E23CDD1 & $35^{\circ} 44^{\prime} 04^{\prime \prime}$ & $90^{\circ} 44^{\prime} 33^{\prime \prime}$ & 88.76 & 93.16 & -4.4 \\
\hline 14N04E22CBD1 & $35^{\circ} 49^{\prime} 29^{\prime \prime}$ & $90^{\circ} 39^{\prime} 21^{\prime \prime}$ & 57.38 & 58.28 & -0.9 \\
\hline 14N05E36CBC1 & $35^{\circ} 47^{\prime} 51^{\prime \prime}$ & $90^{\circ} 31^{\prime} 00^{\prime \prime}$ & 12.4 & 13.62 & -1.2 \\
\hline 15N05E29DBB1 & $35^{\circ} 53^{\prime} 60^{\prime \prime}$ & $90^{\circ} 34^{\prime} 33^{\prime \prime}$ & 23.89 & 25.95 & -2.1 \\
\hline 15N06E18ACA1 & $35^{\circ} 55^{\prime} 44^{\prime \prime}$ & $90^{\circ} 28^{\prime} 58^{\prime \prime}$ & 17.26 & 19.21 & -2.0 \\
\hline \multicolumn{6}{|c|}{ Crittenden County } \\
\hline 06N07E01DAD2 & $35^{\circ} 09^{\prime} 58^{\prime \prime}$ & $90^{\circ} 17^{\prime} 38^{\prime \prime}$ & 26.28 & 23.85 & 2.4 \\
\hline 06N09E23AAB1 & $35^{\circ} 07^{\prime} 45^{\prime \prime}$ & $90^{\circ} 05^{\prime} 53^{\prime \prime}$ & 54.51 & 46.56 & 7.9 \\
\hline 09N07E21BBB1 & $35^{\circ} 23^{\prime} 41^{\prime \prime}$ & $90^{\circ} 21^{\prime} 31^{\prime \prime}$ & 24.87 & 25.12 & -0.3 \\
\hline \multicolumn{6}{|c|}{ Cross County } \\
\hline 06N04E06ACA1 & $35^{\circ} 10^{\prime} 04^{\prime \prime}$ & $90^{\circ} 42^{\prime} 38^{\prime \prime}$ & 206.34 & 202.83 & 3.5 \\
\hline 07N05E04ADD1 & $35^{\circ} 15^{\prime} 38^{\prime \prime}$ & $90^{\circ} 33^{\prime} 30^{\prime \prime}$ & 35.51 & 33.43 & 2.1 \\
\hline 09N01E16CAC1 & $35^{\circ} 24^{\prime} 05^{\prime \prime}$ & $90^{\circ} 59^{\prime} 51^{\prime \prime}$ & 92.09 & 94.8 & -2.7 \\
\hline
\end{tabular}


Appendix 2. Difference in water level from 2007 to 2011 in the Sparta-Memphis aquifer in Arkansas.-Continued

[Horizontal datum is the North American Datum of 1983; negative values denote a decline; 2007 depth-to-water level from Schrader (2009)]

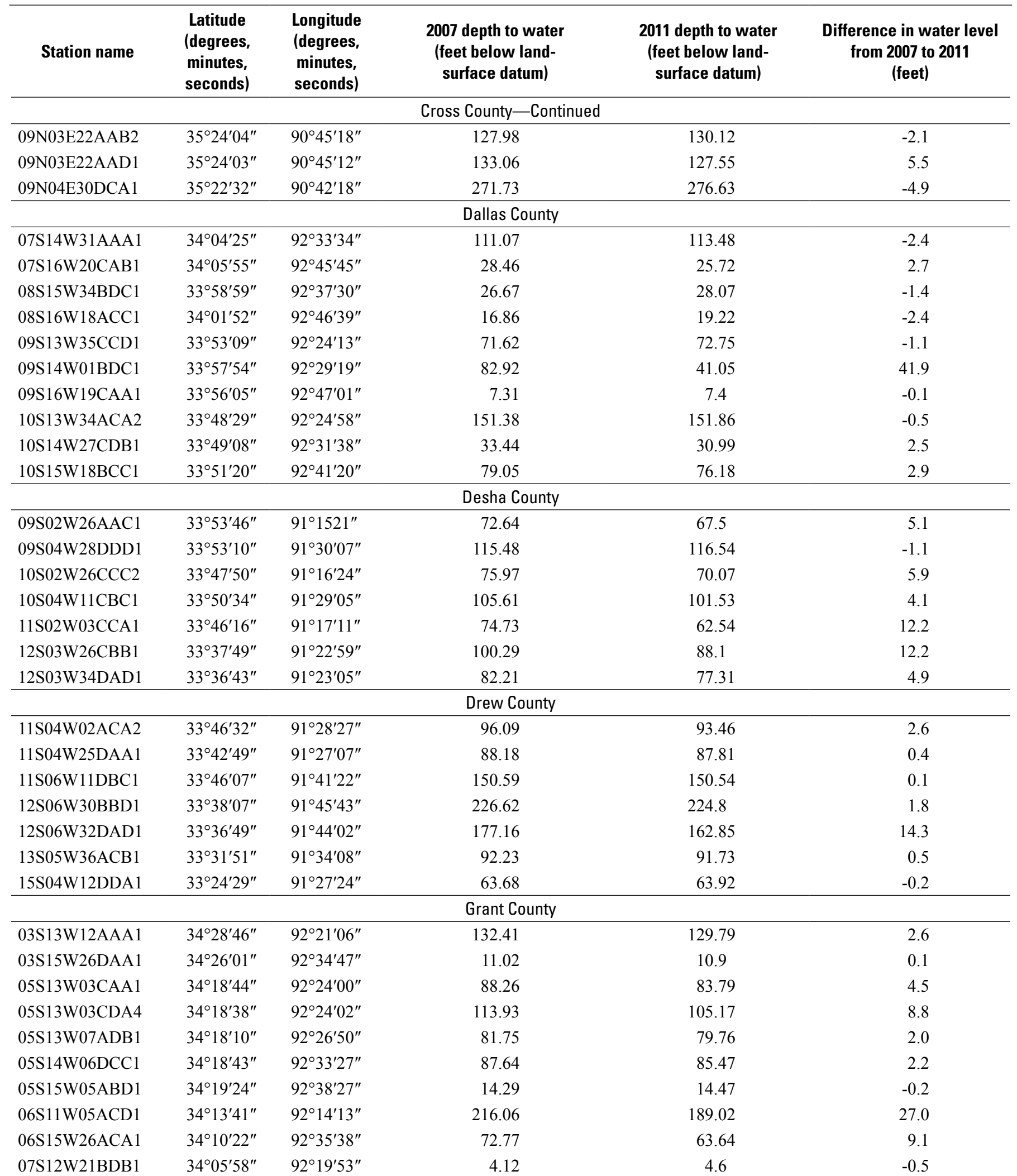


Appendix 2. Difference in water level from 2007 to 2011 in the Sparta-Memphis aquifer in Arkansas. - Continued

[Horizontal datum is the North American Datum of 1983; negative values denote a decline; 2007 depth-to-water level from Schrader (2009)]

\begin{tabular}{|c|c|c|c|c|c|}
\hline Station name & $\begin{array}{l}\text { Latitude } \\
\text { (degrees, } \\
\text { minutes, } \\
\text { seconds) }\end{array}$ & $\begin{array}{l}\text { Longitude } \\
\text { (degrees, } \\
\text { minutes, } \\
\text { seconds) }\end{array}$ & $\begin{array}{l}2007 \text { depth to water } \\
\text { (feet below land- } \\
\text { surface datum) }\end{array}$ & $\begin{array}{l}2011 \text { depth to water } \\
\text { (feet below land- } \\
\text { surface datum) }\end{array}$ & $\begin{array}{c}\text { Difference in water level } \\
\text { from } 2007 \text { to } 2011 \\
\text { (feet) }\end{array}$ \\
\hline \multicolumn{6}{|c|}{ Jefferson County } \\
\hline 03S08W19BAD1 & $34^{\circ} 26^{\prime} 24^{\prime \prime}$ & $91^{\circ} 54^{\prime} 44^{\prime \prime}$ & 173.95 & 169.28 & 4.7 \\
\hline 03S08W19BBD1 & $34^{\circ} 26^{\prime} 28^{\prime \prime}$ & $91^{\circ} 55^{\prime} 05^{\prime \prime}$ & 181.23 & 162.78 & 18.4 \\
\hline 03S10W27AAD1 & $34^{\circ} 25^{\prime} 02^{\prime \prime}$ & $92^{\circ} 04^{\prime} 34^{\prime \prime}$ & 136.63 & 145.83 & -9.2 \\
\hline 03S11W22ABC1 & $34^{\circ} 26^{\prime} 51^{\prime \prime}$ & $92^{\circ} 10^{\prime} 58^{\prime \prime}$ & 176.45 & 170.37 & 6.1 \\
\hline 04S07W17BCC1 & $34^{\circ} 21^{\prime} 40^{\prime \prime}$ & $91^{\circ} 47^{\prime} 42^{\prime \prime}$ & 205.35 & 166.29 & 39.1 \\
\hline 04S08W35BBD1 & $34^{\circ} 19^{\prime} 09^{\prime \prime}$ & $91^{\circ} 50^{\prime} 56^{\prime \prime}$ & 215.5 & 215.4 & 0.1 \\
\hline 04S11W14BAD1 & $34^{\circ} 22^{\prime} 20^{\prime \prime}$ & $92^{\circ} 10^{\prime} 00^{\prime \prime}$ & 313.67 & 320.46 & -6.8 \\
\hline 06S08W16CCC1 & $34^{\circ} 11^{\prime} 43^{\prime \prime}$ & $91^{\circ} 55^{\prime} 17^{\prime \prime}$ & 255.56 & 239.21 & 16.4 \\
\hline 06S08W25ADC1 & $34^{\circ} 10^{\prime} 25^{\prime \prime}$ & $91^{\circ} 51^{\prime} 16^{\prime \prime}$ & 225.35 & 215.09 & 10.3 \\
\hline 06S09W17CAD1 & $34^{\circ} 11^{\prime} 59^{\prime \prime}$ & $92^{\circ} 02^{\prime} 07^{\prime \prime}$ & 263.78 & 255.3 & 8.5 \\
\hline 06S09W17CCA1 & $34^{\circ} 11^{\prime} 52^{\prime \prime}$ & $92^{\circ} 02^{\prime} 21^{\prime \prime}$ & 257.38 & 250.79 & 6.6 \\
\hline 06S10W23ACD1 & $34^{\circ} 11^{\prime} 16^{\prime \prime}$ & $92^{\circ} 05^{\prime} 08^{\prime \prime}$ & 230.84 & 228.1 & 2.7 \\
\hline 06S10W23DBA1 & $34^{\circ} 11^{\prime} 05^{\prime \prime}$ & $92^{\circ} 05^{\prime} 06^{\prime \prime}$ & 248.12 & 232.62 & 15.5 \\
\hline 07S07W24BAB1 & $34^{\circ} 06^{\prime} 33^{\prime \prime}$ & $91^{\circ} 45^{\prime} 23^{\prime \prime}$ & 170.85 & 160.68 & 10.2 \\
\hline 07S10W24CAC1 & $34^{\circ} 05^{\prime} 49^{\prime \prime}$ & $92^{\circ} 04^{\prime} 21^{\prime \prime}$ & 258.8 & 264.83 & -6.0 \\
\hline \multicolumn{6}{|c|}{ Lafayette County } \\
\hline 16S23W12CAD1 & $33^{\circ} 21^{\prime} 43^{\prime \prime}$ & $93^{\circ} 26^{\prime} 09^{\prime \prime}$ & 77.88 & 61.49 & 16.4 \\
\hline \multicolumn{6}{|c|}{ Lee County } \\
\hline 01N04E09CDD1 & $34^{\circ} 4210^{\prime \prime}$ & $90^{\circ} 41^{\prime} 19^{\prime \prime}$ & 62.21 & 66.61 & -4.4 \\
\hline \multicolumn{6}{|c|}{ Lincoln County } \\
\hline 07S07W30CDC1 & $34^{\circ} 04^{\prime} 44^{\prime \prime}$ & $91^{\circ} 50^{\prime} 43^{\prime \prime}$ & 190.05 & 172.32 & 17.7 \\
\hline 08S08W35DBB1 & $33^{\circ} 58^{\prime} 58^{\prime \prime}$ & $91^{\circ} 52^{\prime} 22^{\prime \prime}$ & 228.88 & 217.66 & 11.2 \\
\hline 09S07W07DAD1 & $33^{\circ} 56^{\prime} 34^{\prime \prime}$ & $91^{\circ} 51^{\prime} 28^{\prime \prime}$ & 279.86 & 274.74 & 5.1 \\
\hline \multicolumn{6}{|c|}{ Lonoke County } \\
\hline 01N07W03BCC1 & $34^{\circ} 44^{\prime} 25^{\prime \prime}$ & $91^{\circ} 45^{\prime} 03^{\prime \prime}$ & 131.22 & 136.2 & -5.0 \\
\hline 01S08W02DBD1 & $34^{\circ} 38^{\prime} 55^{\prime \prime}$ & $91^{\circ} 49^{\prime} 60^{\prime \prime}$ & 98.31 & 108.41 & -10.1 \\
\hline 02N07W06ACD1 & $34^{\circ} 49^{\prime} 39^{\prime \prime}$ & $91^{\circ} 47^{\prime} 37^{\prime \prime}$ & 125.85 & 124.51 & 1.3 \\
\hline 02N07W09AAA1 & $34^{\circ} 49^{\prime} 06^{\prime \prime}$ & $91^{\circ} 45^{\prime} 00^{\prime \prime}$ & 101.45 & 102.77 & -1.3 \\
\hline 02N07W22DBA1 & $34^{\circ} 46^{\prime} 51^{\prime \prime}$ & $91^{\circ} 44^{\prime} 26^{\prime \prime}$ & 131.71 & 135.45 & -3.7 \\
\hline 02N07W24DAC1 & $34^{\circ} 46^{\prime} 50^{\prime \prime}$ & $91^{\circ} 42^{\prime} 09^{\prime \prime}$ & 149.65 & 150.94 & -1.3 \\
\hline 02S07W08DCC1 & $34^{\circ} 32^{\prime} 35^{\prime \prime}$ & $91^{\circ} 47^{\prime} 00^{\prime \prime}$ & 143.4 & 141.71 & 1.7 \\
\hline 03N07W03CAA1 & $34^{\circ} 54^{\prime} 45^{\prime \prime}$ & $91^{\circ} 44^{\prime} 26^{\prime \prime}$ & 79.98 & 81.7 & -1.7 \\
\hline 03N08W11ACD1 & $34^{\circ} 54^{\prime} 03^{\prime \prime}$ & $91^{\circ} 49^{\prime} 35^{\prime \prime}$ & 93.65 & 96.43 & -2.8 \\
\hline
\end{tabular}


Appendix 2. Difference in water level from 2007 to 2011 in the Sparta-Memphis aquifer in Arkansas.-Continued

[Horizontal datum is the North American Datum of 1983; negative values denote a decline; 2007 depth-to-water level from Schrader (2009)]

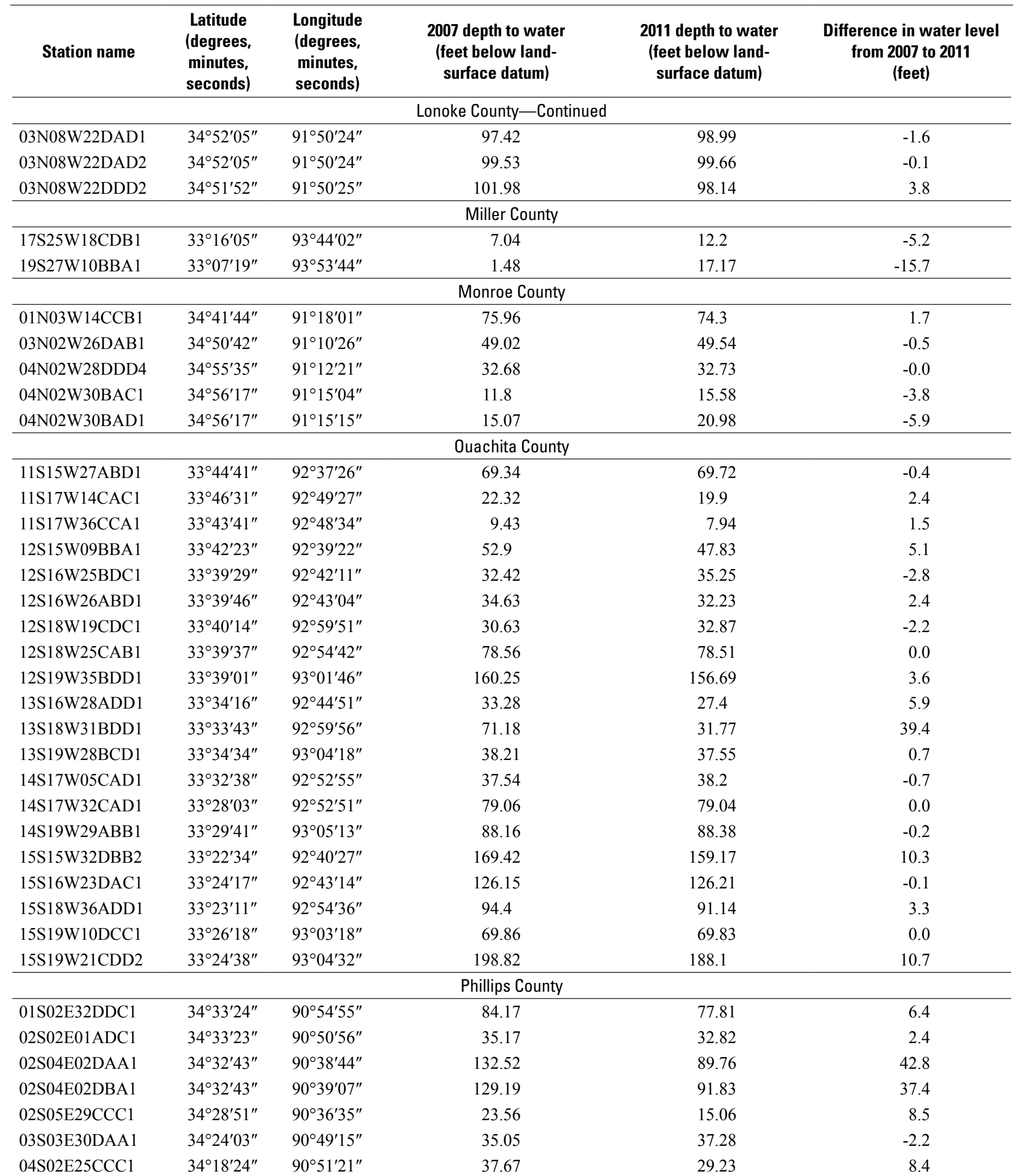


Appendix 2. Difference in water level from 2007 to 2011 in the Sparta-Memphis aquifer in Arkansas. - Continued

[Horizontal datum is the North American Datum of 1983; negative values denote a decline; 2007 depth-to-water level from Schrader (2009)]

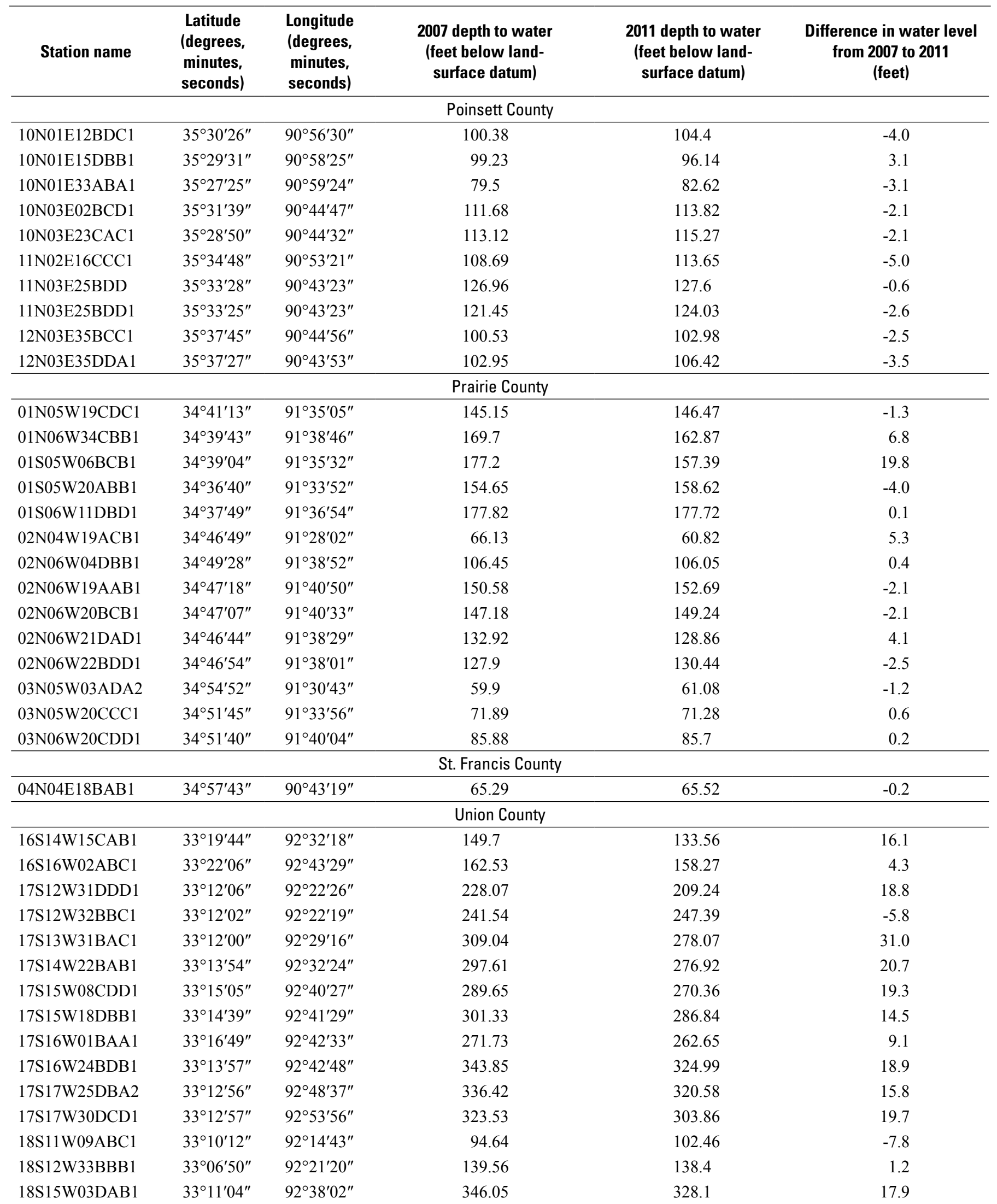


Appendix 2. Difference in water level from 2007 to 2011 in the Sparta-Memphis aquifer in Arkansas.—Continued

[Horizontal datum is the North American Datum of 1983; negative values denote a decline; 2007 depth-to-water level from Schrader (2009)]

\begin{tabular}{|c|c|c|c|c|c|}
\hline Station name & $\begin{array}{l}\text { Latitude } \\
\text { (degrees, } \\
\text { minutes, } \\
\text { seconds) }\end{array}$ & $\begin{array}{l}\text { Longitude } \\
\text { (degrees, } \\
\text { minutes, } \\
\text { seconds) }\end{array}$ & $\begin{array}{l}2007 \text { depth to water } \\
\text { (feet below land- } \\
\text { surface datum) }\end{array}$ & $\begin{array}{l}2011 \text { depth to water } \\
\text { (feet below land- } \\
\text { surface datum) }\end{array}$ & $\begin{array}{c}\text { Difference in water level } \\
\text { from } 2007 \text { to } 2011 \\
\text { (feet) }\end{array}$ \\
\hline 18S15W33ADA1 & $33^{\circ} 06^{\prime} 59^{\prime \prime}$ & $92^{\circ} 38^{\prime} 58^{\prime \prime}$ & 359.87 & 332.36 & 27.5 \\
\hline 18S15W35DAC1 & $33^{\circ} 06^{\prime} 36^{\prime \prime}$ & $92^{\circ} 37^{\prime} 07^{\prime \prime}$ & 283.78 & 261.91 & 21.9 \\
\hline 18S16W12ACB1 & $33^{\circ} 10^{\prime} 29^{\prime \prime}$ & $92^{\circ} 42^{\prime} 32^{\prime \prime}$ & 433.04 & 399.92 & 33.1 \\
\hline 19S10W16CBC1 & $33^{\circ} 03^{\prime} 29^{\prime \prime}$ & $92^{\circ} 09^{\prime} 04^{\prime \prime}$ & 88.33 & 86.55 & 1.8 \\
\hline 19S11W23ACA1 & $33^{\circ} 02^{\prime} 55^{\prime \prime}$ & $92^{\circ} 12^{\prime} 29^{\prime \prime}$ & 152.44 & 151.17 & 1.3 \\
\hline 19S11W25AAA1 & $33^{\circ} 02^{\prime} 18^{\prime \prime}$ & $92^{\circ} 11^{\prime} 13^{\prime \prime}$ & 151.2 & 145.49 & 5.7 \\
\hline 05N01W11ABA1 & $35^{\circ} 04^{\prime} 26^{\prime \prime}$ & $91^{\circ} 04^{\prime} 07^{\prime \prime}$ & 60 & 61.17 & -1.2 \\
\hline 05N01W17DBB1 & $35^{\circ} 03^{\prime} 11^{\prime \prime}$ & $91^{\circ} 07^{\prime} 27^{\prime \prime}$ & 47.36 & 46.74 & 0.6 \\
\hline 05N02W31DCB3 & $35^{\circ} 00^{\prime} 27^{\prime \prime}$ & $91^{\circ} 14^{\prime} 56^{\prime \prime}$ & 16.24 & 13.09 & 3.1 \\
\hline 06N01W13ABA1 & $35^{\circ} 08^{\prime} 52^{\prime \prime}$ & $91^{\circ} 02^{\prime} 54^{\prime \prime}$ & 68.46 & 73.51 & -5.1 \\
\hline 06N01W13ADC1 & $35^{\circ} 08^{\prime} 27^{\prime \prime}$ & $91^{\circ} 02^{\prime} 47^{\prime \prime}$ & 68.38 & 70.11 & -1.7 \\
\hline 07N01W12BCB1 & $35^{\circ} 14^{\prime} 42^{\prime \prime}$ & $91^{\circ} 03^{\prime} 26^{\prime \prime}$ & 67.94 & 68.43 & -0.5 \\
\hline 08N01W12CDA1 & $35^{\circ} 19^{\prime} 34^{\prime \prime}$ & $91^{\circ} 03^{\prime} 11^{\prime \prime}$ & 74.86 & 77.89 & -3.0 \\
\hline 08N02W26ADC1 & $35^{\circ} 17^{\prime} 26^{\prime \prime}$ & $91^{\circ} 10^{\prime} 04^{\prime \prime}$ & 33.83 & 27.06 & 6.8 \\
\hline
\end{tabular}




\section{Water Levels and Water Quality in the Sparta-Memphis Aquifer (Middle Claiborne Aquifer) in Arkansas}

Appendix 3. Specific conductance, temperature, and pH data from wells completed in the Sparta-Memphis aquifer in Arkansas, 2011.

[Horizontal coordinate information is referenced to the North American Datum of 1983 (NAD 83); $\mu \mathrm{S} / \mathrm{cm}$, microsiemens per centimeter at 25 degrees Celsius]

\begin{tabular}{|c|c|c|c|c|c|c|}
\hline Station name & $\begin{array}{l}\text { Latitude } \\
\text { (degrees, } \\
\text { minutes, } \\
\text { seconds) }\end{array}$ & $\begin{array}{l}\text { Longitude } \\
\text { (degrees, } \\
\text { minutes, } \\
\text { seconds) }\end{array}$ & Date & $\begin{array}{c}\text { Specific } \\
\text { conductance } \\
\text { ( } \mathrm{S} / \mathrm{cm})\end{array}$ & $\begin{array}{c}\text { Temperature } \\
\text { (degrees Celsius) }\end{array}$ & $\begin{array}{c}\text { pH } \\
\text { (standard units) }\end{array}$ \\
\hline \multicolumn{7}{|c|}{ Arkansas County } \\
\hline 07S03W06ABC1 & $34^{\circ} 07^{\prime} 02^{\prime \prime}$ & $91^{\circ} 22^{\prime} 48^{\prime \prime}$ & $06 / 23 / 2011$ & 195 & 24.5 & 8.3 \\
\hline 04S01W04CBD1 & $34^{\circ} 22^{\prime} 25^{\prime \prime}$ & $91^{\circ} 08^{\prime} 08^{\prime \prime}$ & $06 / 24 / 2011$ & 868 & 25.4 & 7.8 \\
\hline \multicolumn{7}{|c|}{ Ashley County } \\
\hline 15S07W32DCC1 & $33^{\circ} 21^{\prime} 08^{\prime \prime}$ & $91^{\circ} 50^{\prime} 44^{\prime \prime}$ & $06 / 23 / 2011$ & 834 & 26.1 & 8.6 \\
\hline \multicolumn{7}{|c|}{ Bradley County } \\
\hline 13S09W06ABD3 & $35^{\circ} 36^{\prime} 52^{\prime \prime}$ & $92^{\circ} 04^{\prime} 13^{\prime \prime}$ & $06 / 23 / 2011$ & 403 & 26.4 & 8.3 \\
\hline 11S14W12CAC3 & $33^{\circ} 46^{\prime} 30^{\prime \prime}$ & $92^{\circ} 29^{\prime} 28^{\prime \prime}$ & $06 / 22 / 2011$ & 185 & 21.9 & 6.5 \\
\hline \multicolumn{7}{|c|}{ Clark County } \\
\hline 09S20W31CAD1 & $33^{\circ} 54^{\prime} 35^{\prime \prime}$ & $93^{\circ} 11^{\prime} 11^{\prime \prime}$ & $06 / 30 / 2011$ & 486 & 22.2 & 7.8 \\
\hline \multicolumn{7}{|c|}{ Clay County } \\
\hline 20N08E14BAB2 & $36^{\circ} 22^{\prime} 27^{\prime \prime}$ & $90^{\circ} 11^{\prime} 20^{\prime \prime}$ & $06 / 29 / 2011$ & 712 & 25.4 & 8.2 \\
\hline \multicolumn{7}{|c|}{ Cleveland County } \\
\hline 11S11W16AAB1 & $33^{\circ} 45^{\prime} 43^{\prime \prime}$ & $92^{\circ} 14^{\prime} 23^{\prime \prime}$ & $06 / 23 / 2011$ & 350 & 25.2 & 8.3 \\
\hline 09S09W04BBD1 & $33^{\circ} 58^{\prime} 20^{\prime \prime}$ & $92^{\circ} 02^{\prime} 37^{\prime \prime}$ & $06 / 22 / 2011$ & 179 & 25.8 & 7.1 \\
\hline \multicolumn{7}{|c|}{ Craighead County } \\
\hline 14N04E28DBD1 & $35^{\circ} 48^{\prime} 37^{\prime \prime}$ & $90^{\circ} 39^{\prime} 53^{\prime \prime}$ & $06 / 29 / 2011$ & 180 & 19.6 & 6.4 \\
\hline \multicolumn{7}{|c|}{ Crittenden County } \\
\hline 06N09E23AAB1 & $35^{\circ} 07^{\prime} 45^{\prime \prime}$ & $90^{\circ} 05^{\prime} 53^{\prime \prime}$ & $06 / 29 / 2011$ & 263 & 19.7 & 6.6 \\
\hline \multicolumn{7}{|c|}{ Cross County } \\
\hline 07N05E04ADD1 & $35^{\circ} 15^{\prime} 38^{\prime \prime}$ & $90^{\circ} 33^{\prime} 30^{\prime \prime}$ & $06 / 28 / 2011$ & 207 & 20.8 & 7.1 \\
\hline 09N04E30DCA1 & $35^{\circ} 22^{\prime} 32^{\prime \prime}$ & $90^{\circ} 42^{\prime} 18^{\prime \prime}$ & $06 / 28 / 2011$ & 474 & 21.9 & 7.3 \\
\hline 09N01E16CAC1 & $35^{\circ} 24^{\prime} 05^{\prime \prime}$ & $90^{\circ} 59^{\prime} 51^{\prime \prime}$ & $06 / 28 / 2011$ & 492 & 18.5 & 7.4 \\
\hline \multicolumn{7}{|c|}{ Dallas County } \\
\hline 10S13W34ACA2 & $33^{\circ} 48^{\prime} 29^{\prime \prime}$ & $92^{\circ} 24^{\prime} 58^{\prime \prime}$ & $06 / 22 / 2011$ & 254 & 23.9 & 7.2 \\
\hline 07S14W31AAA1 & $34^{\circ} 04^{\prime} 25^{\prime \prime}$ & $92^{\circ} 33^{\prime} 34^{\prime \prime}$ & $06 / 22 / 2011$ & 133 & 22.1 & 6.5 \\
\hline \multicolumn{7}{|c|}{ Desha County } \\
\hline 12S03W34DAD1 & $33^{\circ} 36^{\prime} 43^{\prime \prime}$ & $91^{\circ} 23^{\prime} 05^{\prime \prime}$ & $06 / 23 / 2011$ & 365 & 25.6 & 8.5 \\
\hline 09S02W26AAC1 & $33^{\circ} 53^{\prime} 46^{\prime \prime}$ & $91^{\circ} 15^{\prime} 21^{\prime \prime}$ & $06 / 23 / 2011$ & 244 & 22.2 & 8.7 \\
\hline
\end{tabular}


Appendix 3. Specific conductance, temperature, and $\mathrm{pH}$ data from wells completed in the Sparta-Memphis aquifer in Arkansas, 2011.-Continued

[Horizontal coordinate information is referenced to the North American Datum of 1983 (NAD 83); $\mu \mathrm{S} / \mathrm{cm}$, microsiemens per centimeter at 25 degrees Celsius]

\begin{tabular}{|c|c|c|c|c|c|c|}
\hline Station name & $\begin{array}{c}\text { Latitude } \\
\text { (degrees, } \\
\text { minutes, } \\
\text { seconds) }\end{array}$ & $\begin{array}{l}\text { Longitude } \\
\text { (degrees, } \\
\text { minutes, } \\
\text { seconds) }\end{array}$ & Date & $\begin{array}{c}\text { Specific } \\
\text { conductance } \\
\text { ( } \mathrm{S} / \mathrm{cm})\end{array}$ & $\begin{array}{c}\text { Temperature } \\
\text { (degrees Celsius) }\end{array}$ & $\begin{array}{c}\mathrm{pH} \\
\text { (standard units) }\end{array}$ \\
\hline \multicolumn{7}{|c|}{ Drew County } \\
\hline 13S05W36ACB1 & $33^{\circ} 31^{\prime} 51^{\prime \prime}$ & $91^{\circ} 34^{\prime} 08^{\prime \prime}$ & $06 / 23 / 2011$ & 335 & 24.6 & 8.6 \\
\hline 11S05W21CDC1 & $33^{\circ} 43^{\prime} 52^{\prime \prime}$ & $91^{\circ} 37^{\prime} 24^{\prime \prime}$ & $06 / 23 / 2011$ & 288 & 21.9 & 8.8 \\
\hline 06S15W26ACA1 & $34^{\circ} 10^{\prime} 22^{\prime \prime}$ & $92^{\circ} 35^{\prime} 38^{\prime \prime}$ & $06 / 22 / 2011$ & 55 & 19.8 & 5.4 \\
\hline 05S14W06DCC1 & $34^{\circ} 18^{\prime} 43^{\prime \prime}$ & $92^{\circ} 33^{\prime} 27^{\prime \prime}$ & $06 / 27 / 2011$ & 96 & 20.9 & 6.1 \\
\hline \multicolumn{7}{|c|}{ Jefferson County } \\
\hline 06S10W23DBA1 & $34^{\circ} 11^{\prime} 05^{\prime \prime}$ & $92^{\circ} 05^{\prime} 06^{\prime \prime}$ & $06 / 27 / 2011$ & 154 & 24.0 & 7.4 \\
\hline \multicolumn{7}{|c|}{ Lafayette County } \\
\hline 20S23W05ADB1 & $33^{\circ} 02^{\prime} 23^{\prime \prime}$ & $93^{\circ} 30^{\prime} 36^{\prime \prime}$ & $06 / 20 / 2011$ & 273 & 21.1 & 7.5 \\
\hline \multicolumn{7}{|c|}{ Lincoln County } \\
\hline 09S07W07DAD1 & $33^{\circ} 56^{\prime} 34^{\prime \prime}$ & $91^{\circ} 51^{\prime} 28^{\prime \prime}$ & $06 / 23 / 2011$ & 196 & 26.6 & 7.6 \\
\hline 08S05W35ACC1 & $33^{\circ} 59^{\prime} 07^{\prime \prime}$ & $91^{\circ} 33^{\prime} 37^{\prime \prime}$ & $06 / 23 / 2011$ & 232 & 22.0 & 8.3 \\
\hline 07S06W33BAA1 & $34^{\circ} 04^{\prime} 45^{\prime \prime}$ & $91^{\circ} 41^{\prime} 40^{\prime \prime}$ & $06 / 23 / 2011$ & 194 & 24.9 & 8.3 \\
\hline \multicolumn{7}{|c|}{ Lonoke County } \\
\hline 02N07W32DDD1 & $34^{\circ} 44^{\prime} 53^{\prime \prime}$ & $91^{\circ} 46^{\prime} 19^{\prime \prime}$ & $06 / 27 / 2011$ & 450 & 20.5 & 7.1 \\
\hline 04N02W30BAC1 & $34^{\circ} 56^{\prime} 17^{\prime \prime}$ & $91^{\circ} 15^{\prime} 04^{\prime \prime}$ & $06 / 28 / 2011$ & 1,380 & 18.2 & 7.7 \\
\hline \multicolumn{7}{|c|}{ Nevada County } \\
\hline 14S21W20AAB1 & $33^{\circ} 30^{\prime} 50^{\prime \prime}$ & $93^{\circ} 17^{\prime} 23^{\prime \prime}$ & $06 / 23 / 2011$ & 338 & 26.7 & 8.2 \\
\hline 14S21W04CCB1 & $33^{\circ} 32^{\prime} 51^{\prime \prime}$ & $93^{\circ} 17^{\prime} 08^{\prime \prime}$ & 06/30/2011 & 144 & 20.8 & 6.6 \\
\hline \multicolumn{7}{|c|}{ Ouachita County } \\
\hline 15S19W10DCC1 & $33^{\circ} 26^{\prime} 18^{\prime \prime}$ & $93^{\circ} 03^{\prime} 18^{\prime \prime}$ & $06 / 20 / 2011$ & 186 & 22.0 & 6.6 \\
\hline 12S16W26BAA1 & $33^{\circ} 39^{\prime} 48^{\prime \prime}$ & $92^{\circ} 43^{\prime} 04^{\prime \prime}$ & $07 / 05 / 2011$ & 223 & 19.9 & 6.9 \\
\hline 12S19W14AAA1 & $33^{\circ} 41^{\prime} 43^{\prime \prime}$ & $93^{\circ} 01^{\prime} 05^{\prime \prime}$ & 06/30/2011 & 35 & 18.0 & 5.4 \\
\hline \multicolumn{7}{|c|}{ Phillips County } \\
\hline 04S02E25CCC1 & $34^{\circ} 18^{\prime} 24^{\prime \prime}$ & $90^{\circ} 51^{\prime} 21^{\prime \prime}$ & $06 / 24 / 2011$ & 1,190 & 22.9 & 8.3 \\
\hline \multicolumn{7}{|c|}{ Poinsett County } \\
\hline 10N01E15DBB1 & $35^{\circ} 29^{\prime} 31^{\prime \prime}$ & $90^{\circ} 58^{\prime} 25^{\prime \prime}$ & $06 / 28 / 2011$ & 499 & 18.6 & 7.4 \\
\hline \multicolumn{7}{|c|}{ Prairie County } \\
\hline 02N06W20BCB1 & $34^{\circ} 47^{\prime} 07^{\prime \prime}$ & $91^{\circ} 40^{\prime} 33^{\prime \prime}$ & $06 / 27 / 2011$ & 342 & 21.6 & 6.9 \\
\hline
\end{tabular}




\section{Water Levels and Water Quality in the Sparta-Memphis Aquifer (Middle Claiborne Aquifer) in Arkansas}

Appendix 3. Specific conductance, temperature, and pH data from wells completed in the Sparta-Memphis aquifer in Arkansas, 2011.-Continued

[Horizontal coordinate information is referenced to the North American Datum of 1983 (NAD 83); $\mu \mathrm{S} / \mathrm{cm}$, microsiemens per centimeter at 25 degrees Celsius]

\begin{tabular}{|c|c|c|c|c|c|c|}
\hline Station name & $\begin{array}{l}\text { Latitude } \\
\text { (degrees, } \\
\text { minutes, } \\
\text { seconds) }\end{array}$ & $\begin{array}{l}\text { Longitude } \\
\text { (degrees, } \\
\text { minutes, } \\
\text { seconds) }\end{array}$ & Date & $\begin{array}{c}\text { Specific } \\
\text { conductance } \\
(\mu \mathrm{S} / \mathrm{cm})\end{array}$ & $\begin{array}{c}\text { Temperature } \\
\text { (degrees Celsius) }\end{array}$ & $\begin{array}{c}\mathrm{pH} \\
\text { (standard units) }\end{array}$ \\
\hline \multicolumn{7}{|c|}{ Union County } \\
\hline 19S16W35DDC1 & $33^{\circ} 01^{\prime} 09^{\prime \prime}$ & $92^{\circ} 43^{\prime} 26^{\prime \prime}$ & $07 / 05 / 2011$ & 546 & 24.6 & 8.7 \\
\hline 19S11W25AAA1 & $33^{\circ} 02^{\prime} 18^{\prime \prime}$ & $92^{\circ} 11^{\prime} 13^{\prime \prime}$ & $07 / 05 / 2011$ & 1,060 & 23.1 & 8.8 \\
\hline 18S14W06CCD1 & $33^{\circ} 10^{\prime} 39^{\prime \prime}$ & $92^{\circ} 35^{\prime} 31^{\prime \prime}$ & $06 / 21 / 2011$ & 722 & 24.1 & 8.6 \\
\hline 17S13W31BAD1 & $33^{\circ} 12^{\prime} 04^{\prime \prime}$ & $92^{\circ} 29^{\prime} 07^{\prime \prime}$ & $07 / 05 / 2011$ & 723 & 26.2 & 8.8 \\
\hline 17S17W30DCD1 & $33^{\circ} 12^{\prime} 57^{\prime \prime}$ & $92^{\circ} 53^{\prime} 56^{\prime \prime}$ & $07 / 05 / 2011$ & 317 & 26.2 & 8.4 \\
\hline 17S16W24BDB1 & $33^{\circ} 13^{\prime} 57^{\prime \prime}$ & $92^{\circ} 42^{\prime} 48^{\prime \prime}$ & $07 / 05 / 2011$ & 413 & 23.2 & 8.6 \\
\hline \multicolumn{7}{|c|}{ Woodruff County } \\
\hline 05N02W31DCB3 & $35^{\circ} 00^{\prime} 27^{\prime \prime}$ & $91^{\circ} 14^{\prime} 56^{\prime \prime}$ & $06 / 28 / 2011$ & 230 & 18.0 & 7.4 \\
\hline
\end{tabular}


